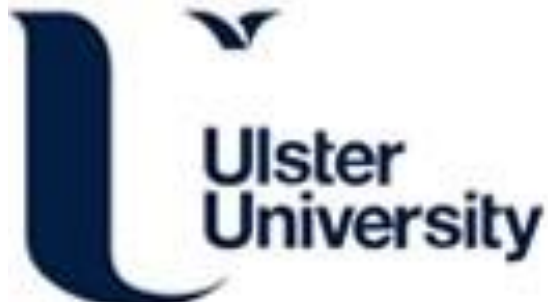

\section{Performance analysis of solar assisted heat pump coupled with build-in PCM heat storage based on PV/T panel}

Yao, J., Xu, H., Dai, Y., \& Huang, M. (2020). Performance analysis of solar assisted heat pump coupled with build-in PCM heat storage based on PV/T panel. Solar Energy, 197, 279-291.

https://doi.org/10.1016/j.solener.2020.01.002

Link to publication record in Ulster University Research Portal

Published in:

Solar Energy

Publication Status:

Published (in print/issue): 01/02/2020

DOI:

10.1016/j.solener.2020.01.002

\section{Document Version}

Author Accepted version

\section{General rights}

Copyright for the publications made accessible via Ulster University's Research Portal is retained by the author(s) and / or other copyright owners and it is a condition of accessing these publications that users recognise and abide by the legal requirements associated with these rights.

\section{Take down policy}

The Research Portal is Ulster University's institutional repository that provides access to Ulster's research outputs. Every effort has been made to ensure that content in the Research Portal does not infringe any person's rights, or applicable UK laws. If you discover content in the Research Portal that you believe breaches copyright or violates any law, please contact pure-support@ulster.ac.uk. 
Manuscript Number: SE-D-19-01268R3

Title: Performance analysis of solar assisted heat pump coupled with build-in PCM heat storage based on $\mathrm{PV} / \mathrm{T}$ panel

Article Type: VSI:Solar Integration

Keywords: PV/T; Solar energy; Heat pump; Build-in PCM heat storage; Heating/Power generation; Residential heating

Corresponding Author: Professor Yanjun DAI, Ph.D

Corresponding Author's Institution: Shanghai Jiao Tong University

First Author: Jian YAO

Order of Authors: Jian YAO; Hui XU; Yanjun DAI, Ph.D; Mingjun HUANG

Manuscript Region of Origin: CHINA

Abstract: PV/T (photovoltaic/thermal) technology is a combination of PV module (photovoltaic utilization) and collector (photothermal utilization), which can improve the comprehensive utilization efficiency of solar energy and has a broad application prospect. In this paper, PV/T module is coupled with heat pump evaporator to form a direct-expansion solar PV/T heat pump which is suitable for heat application in high latitude area. To achieve stable residential heating, a solar PV/T heat pump system coupled with build-in PCM (phase change material) heat storage is therefore proposed and simulated. Meanwhile, the mathematical model of solar PV/T heat pump coupled with build-in PCM heat storage system is established and verified. The simulation results show that the temperature of underfloor heating which using build-in PCM heat storage can reach $22{ }^{\circ} \mathrm{C}$ to $31{ }^{\circ} \mathrm{C}$ after 39 hours when the circulating water is 40 ${ }^{\circ} \mathrm{C}$. Moreover, the heating COP (Coefficient of Performance) increases with the increase of solar radiation, ambient temperature and area of $\mathrm{PV} / \mathrm{T}$ collector, and decrease of wind speed, respectively. A $20 \mathrm{~m} 2 \mathrm{PV} / \mathrm{T}$ panel module can output $21.4 \%$ of the electricity to power grid when the solar radiation intensity is $600 \mathrm{~W} / \mathrm{m} 2$ and meet the heat demand of a $100 \mathrm{~m} 2$ room while maintain the operation of the system. Meanwhile, the heating COP can reach 5.79 which is $70 \%$ higher than the conventional air conditioning system and the electrical, thermal, overall efficiencies are 17.77\%, $55.76 \%$ and $75.49 \%$, respectively. 


\section{Highlights}

- A solar assisted heating/power generation system based on PV/T panel is proposed for residential heating in high latitude area.

- Design of build-in PCM heat storage unit is proposed and simulated.

- The comprehensive energy utilization efficiency of this solar PV/T heat pump system can reach above $75 \%$. 


\section{Dear editor and reviewers:}

Thanks for your responsible comments on our manuscript. It is very valuable and helpful to improve our paper. We have revised the manuscript carefully according to your suggestions. The revised portions are marked in red in the revised manuscript.

\section{Reviewer 1}

\#1. The validation process are wrong. Firstly, the system reported in the manuscript is totally different from the validation case, which comes from the last Reference, Zhou et al. 2019. In Zhou's study, there is no any pcm thermal energy storage (PCM-TES) unit, while the PCM-TES unit in this study is the novelty in the system. By using different system to validate this work, it is hardly possible to get reasonable results, even the given data seems agree well.

Response: Thanks for your comments. As shown in Fig. 2, the solar PV/T heat pump cycle is the main sub cycle of the proposed system. In Zhou's paper, they proposed a solar PV/T heat pump system which has the same components (PV/T collector/evaporator, compressor, condenser, expansion valve). The only difference between Zhou's paper and our proposed system is that in our proposed system, the thermal energy will be stored in build-in PCM heat storage unit, but in Zhou's system, it will be stored directly in hot water tank. In other words, the difference is just the type of heat storage, in PCM-TES or in water tank. Therefore, the added PCM-TES unit in our proposed system will not influence the performance of solar PV/T heat pump system (For example, thermodynamic state points of each components, thermal energy gain through PV/T panel, heat of condensation, etc.). It's reasonable to refer Zhou's experiments results for validation due to the same basic thermodynamic cycle and operating conditions.

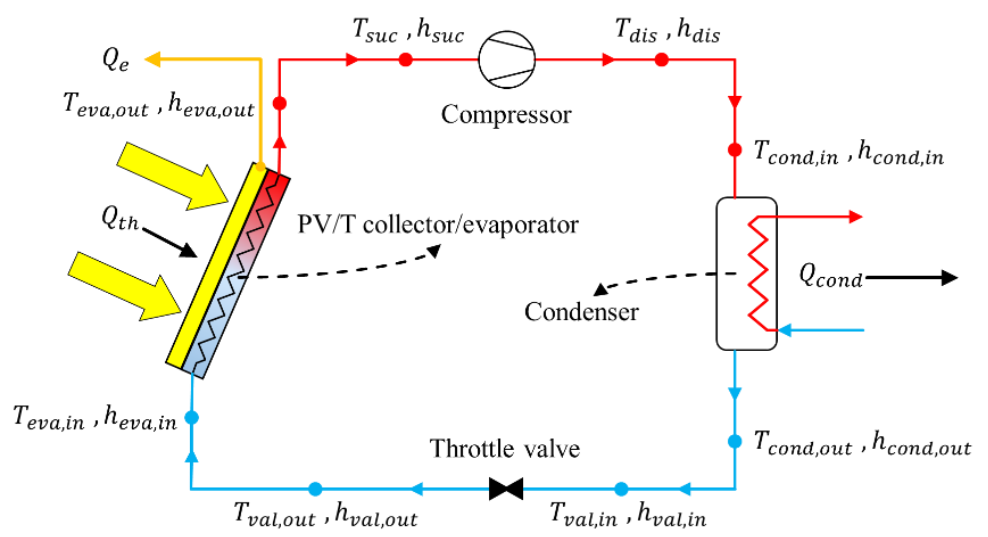

Fig. 2. The thermodynamic state points for each component.

\#2. In Fig. 12, there is simulated photovoltaic efficiency. How to simulate it? It is totally influences by the material and structure of the PV panel. It seems hardly possible to simulate its performance. Furthermore, even there is some semi-empirical calculated data, it can not be used to validate the coupled system reported in this study. Only by using the same system, the model could be validated. It seems common sense. 
Response: Thank you for your comments. According to Huide's paper, the photovoltaic efficiency can be calculated by Eq. (2). $\eta_{r c}$ is the reference photovoltaic efficiency value of the PV cells at $T_{r c}=298 \mathrm{~K}, I=1000 \mathrm{~W} / \mathrm{m}^{2}, \eta_{r c}=0.18 ; \beta_{p v}$ is the temperature coefficient $(1 / \mathrm{K})$ of PV cell efficiency, $\beta_{p v}=0.0045$ (Huide et al., 2017).

$$
\eta_{e}=\eta_{r c} \cdot\left[1-\beta_{p v} \cdot\left(T_{p}-T_{r c}\right)\right]
$$

As shown in Eq. (2), the reference photovoltaic efficiency $\left(\eta_{r c}\right)$ is determined by material and structure of PV panel. However, the photovoltaic efficiency $\left(\eta_{e}\right)$ is only influenced by PV cells' temperature $\left(T_{p}\right)$ which could be simulated when the material and structure is fixed.

The simulation process of PV cells' temperature is as follows: firstly, input all the environmental, system design, operation parameters and assume the temperature of PV cells $\left(T_{p}\right)$. Secondly, calculate the overall heat loss rate $\left(Q_{L}\right)$, PV electrical output power $\left(Q_{e}\right)$, thermal energy gain rate through $\mathrm{PV} / \mathrm{T}$ collector/evaporator $\left(Q_{t h}\right)$ and the useful heat transfer rate by refrigerant $\left(Q_{u}\right)$. Then the program starts iteration and moves to next step when $\left|\left(Q_{t h^{-}} Q_{u}\right) / Q_{t h}\right|<0.1 \%$ which means the system achieves energy balance. If $\left|\left(Q_{t h^{-}} Q_{u}\right) / Q_{t h}\right| \geq 0.1 \%$, the PV cells' temperature $\left(T_{p}\right)$ would be modified and the program would start another iteration using the modified $T_{p}$. Thus, the PV cells' temperature could be calculated through the program as well as the photovoltaic efficiency. The algorithm has been presented in section 3.5.

The proposed system has the same thermodynamic cycle and operating conditions with Zhou's study which consist of PV/T collector/evaporator, compressor, condenser, expansion valve. Compared to Zhou's system, the only difference is that the proposed system has added a thermal storage part which will not influence the heat pump system's performance. Thus, the proposed solar PV/T heat pump system could be validated by Zhou's system.

\#3. There are too many figures and tables are useless in this manuscript, which makes this manuscript long and even dull. For example, Fig. $3 \mathrm{c}$ is not mentioned at all.

I do know why authors use the solar radiation intensity data in Figs. 11 and 12, but not mentioned them at all. This makes the figures much more complex.

Response: Thank you for your comments. The authors have revised the manuscript, several figures have been deleted and Fig. 11, Fig. 12 have been modified. The revised figures are listed as follows:

1. Fig. $3(\mathrm{c})(\mathrm{d})$ have been deleted.

2. Fig. 8 (c $\sim 1)$ have been deleted.

3. Fig. 26 has been deleted.

4. Fig. 11 and Fig. 12 have been revised to Fig. 11. (a)(b) according to your comments. The curves of solar radiation intensity have been deleted in revised Fig. 11. (a)(b) and these two figures are simpler and easier to understand. 

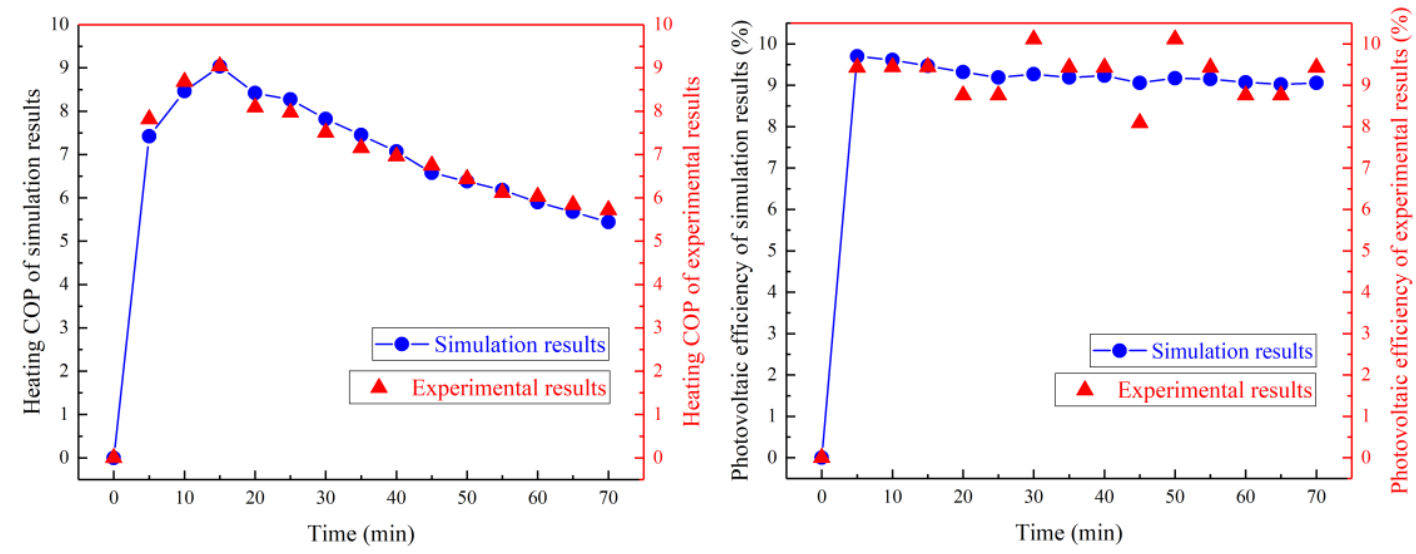

Fig. 11. (a) Comparison results of experimental and simulated heating COP. (b) Comparison results of experimental and simulated photovoltaic efficiency.

\#4. Many unimportant results are given in the conclusions, such as the following one.

(2) The heating COP increases with the increase of solar radiation, ambient temperature, area of $\mathrm{PV} / \mathrm{T}$ collector, and decrease of wind speed, respectively. Solar radiation intensity and area of $\mathrm{PV} / \mathrm{T}$ collector are two major factors affecting system performance compared to wind speed and ambient temperature.

As far as I know, this conclusion could be given even this work is not conducted. It could be given easily. Clearly, the novelty of this work is lack.

Response: Thank you for your comments. The second conclusion in Line 625-628 has been deleted according to your comments. The novelty of this work has been added in section Introduction in Line 102-104.

The revised manuscript of Line 102-104 is as follows:

The objective of this paper is to provide a promising method to realize stable, high efficiency, environmental friendly residential heating in high latitude area with no energy consumption from power grid.

\#5. Even authors revised the manuscript many times, there are still many problems. For example, in Fig.8, the color bar starts at different temperatures, 290 K, 300 K, 287 K, 297 K, etc. Why?

Response: Thank you for your comments. According to your Comment \#3, Fig. 8 (c 1$)$ have been deleted. The color bar starts at the same temperature in revised Fig. 8 (a)(b)(c).

The revised manuscript of Fig. 8 is as follows: 


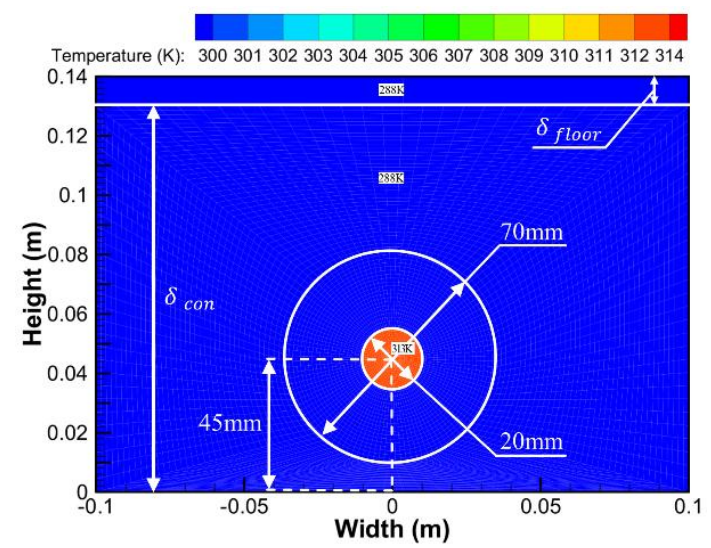

(a) Initial stage

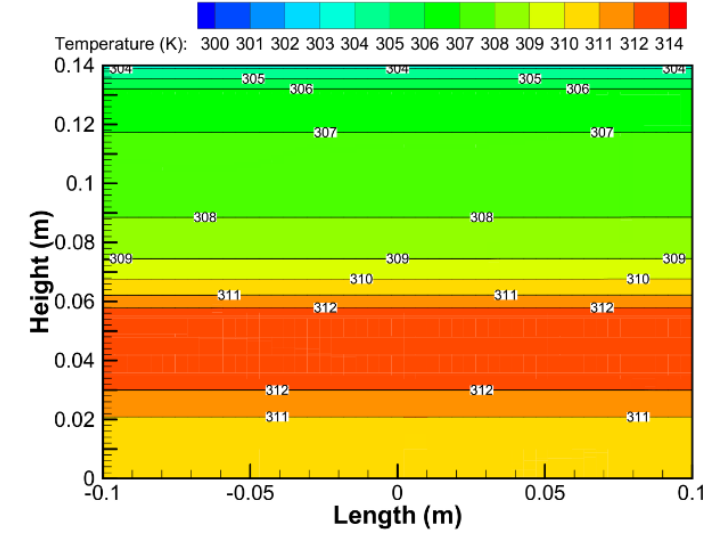

(c) Cross-section view at the width of 0 (steady stage)

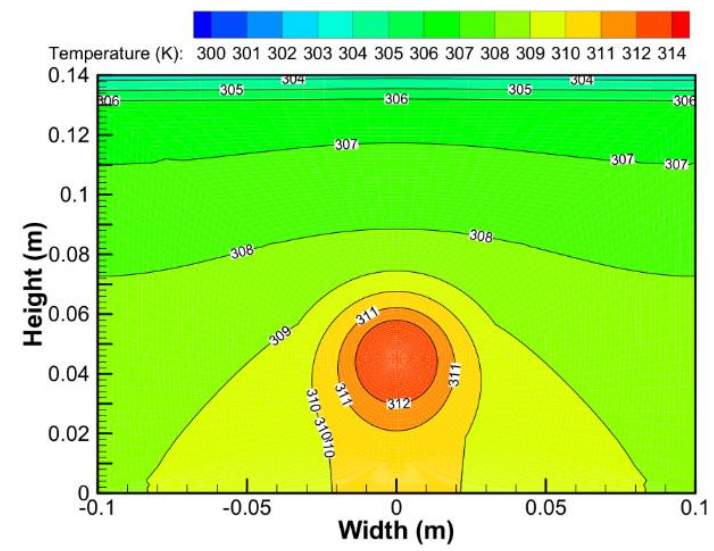

(b) Steady stage

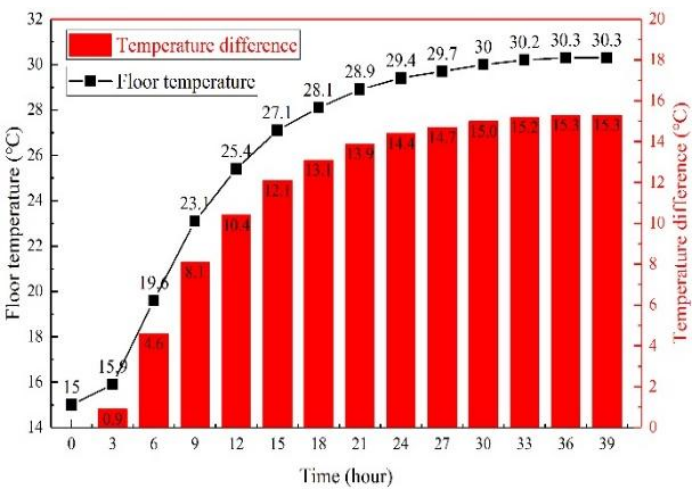

(d)

Fig. 8. (a c) Cross-section temperature contour of the build-in PCM heat storage unit at initial and steady stage. (d) Variation curve of floor temperature and temperature difference between floor and ambient.

\#6. The manuscript has a poor structure, and the length could be divided into 2-3 articles. It is hard to make reader understand the main goal of this work from this manuscript.

Response: Thank you for your comments.

Our structure for writing this article is as follows: we firstly propose the solar PV/T heat pump system coupled with build-in PCM heat storage. Then, we design and evaluate the build-in PCM heat storage. Next, we therefore investigate the performance of solar PV/T heat pump system coupled with PCM-TES. Finally, we conduct the feasibility analysis and merits of the proposed system.

The main goal of this paper which has been added in Line 102-104 is to provide a promising method to realize stable, high efficiency, environmental friendly residential heating in high latitude area with no energy consumption from power grid.

According to your comments, several paragraphs have been deleted. The revised parts in manuscript are as follows:

1. Line 104-106.

2. Line 160-161.

3. Line 164-165. 
4. Line 248-255.

5. Line 303-308.

6. Line 606-611.

7. Line 625-628.

\section{Reviewer 5}

The authors have made clear responses. Now the present manuscript is acceptable for publication.

Response: Thank you for your comments. 


\title{
Performance analysis of solar assisted heat pump coupled with build-in PCM heat storage based on PV/T panel
}

$\mathrm{PV} / \mathrm{T}$ (photovoltaic/thermal) technology is a combination of PV module (photovoltaic utilization) and collector (photothermal utilization), which can improve the comprehensive utilization efficiency of solar energy and has a broad application prospect. In this paper, PV/T module is coupled with heat pump evaporator to form a direct-expansion solar PV/T heat pump which is suitable for heat application in high latitude area. To achieve stable residential heating, a solar PV/T heat pump system coupled with build-in PCM (phase change material) heat storage is therefore proposed and simulated. Meanwhile, the mathematical model of solar PV/T heat pump coupled with build-in PCM heat storage system is established and verified. The simulation results show that the temperature of underfloor heating which using build-in PCM heat storage can reach $22{ }^{\circ} \mathrm{C}$ to $31^{\circ} \mathrm{C}$ after 39 hours when the circulating water is $40{ }^{\circ} \mathrm{C}$. Moreover, the heating COP (Coefficient of Performance) increases with the increase of solar radiation, ambient temperature and area of PV/T collector, and decrease of wind speed, respectively. A $20 \mathrm{~m}^{2} \mathrm{PV} / \mathrm{T}$ panel module can output $21.4 \%$ of the electricity to power grid when the solar radiation intensity is $600 \mathrm{~W} / \mathrm{m}^{2}$ and meet the heat demand of a $100 \mathrm{~m}^{2}$ room while maintain the operation of the system. Meanwhile, the heating COP can reach 5.79 which is $70 \%$ higher than the conventional air conditioning system and the electrical, thermal, overall efficiencies are $17.77 \%, 55.76 \%$ and $75.49 \%$, respectively.

\section{Introduction}

The total amount of energy consumption in the world is constantly climbing (2019; Caetano et al., 2017). The consumption of fossil energy has brought about energy crisis and environmental crisis (Pietrosemoli and Rodríguez-Monroy, 2019). Without action, $\mathrm{CO}_{2}$ emissions from burning fossil fuels will be doubled by 2050 (Paolo Frankl, 2010). Therefore, the development and utilization of renewable energy has become one of the effective solutions (Keček et al., 2019). Solar energy has become the first choice due to its characteristics of ubiquity, abundance and sustainability (Kuik et al., 2019; Tsai, 2015), which is mainly used in two ways: photothermal and photovoltaic. 11\% of global electricity will be provided by PV by 2050 (Paolo Frankl, 2010). However, the electrical efficiency of PV cells decreases with the increase of the temperature of PV cells (Huide et al., 2017). A cooling system can be added to reduce the temperature of PV cells while the remaining heat of PV panel are absorbed by working fluid which can be employed as a useful thermal energy for heat applications in buildings. 
The PV/T technology coupled PV modules with thermal collectors was first proposed by Wolf et al (Wolf, 1976) to reduce PV cells temperature and improve electrical efficiency. The $\mathrm{PV} / \mathrm{T}$ system can recover waste heat from the PV panel to improve comprehensive energy utilization efficiency. PV/T design optimizations are carried out to improve the system efficiency in recent years. Nahar et al. (Nahar et al., 2017) designed a novel pancake-shaped flow channel for PV/T system, and integrated the flow channel with the PV baseboard. They found that the temperature of the PV panel is reduced by $42{ }^{\circ} \mathrm{C}$, and the electrical efficiency is increased by $2 \%$. Othman et al. (Othman et al., 2016) proposed a parallel, double pass flat plate collector which was adopted in a two fluids PV/T system. Their results showed that the electrical efficiency and thermal efficiency are $17 \%$ and $76 \%$, respectively.

The combination of PCM and PV/T panel is an effective way to stabilize the operating temperature of PV cells and improves the overall efficiency. Hosseinzadeh et al. (Hosseinzadeh et al., 2018) investigated the effect of simultaneous use of nanofluid as coolant as well as an organic paraffin as the phase change material on the electrical and thermal efficiencies. They demonstrated that the use of PCM in nanofluid based PVT/PCM system enhances the thermal output power of conventional PV/T system by $29.6 \%$. Kazemian et al. (Kazemian et al., 2019) developed and simulated a comprehensive three-dimensional model of PV/T system integrated with PCM. Their simulation results presented that the PV/T-PCM system have lower surface temperature compared to PV/T system, and as the thermal conductivity of PCM enhances, both electrical and thermal efficiencies increase. Fayaz et al. (Fayaz et al., 2019) investigated the PCM based PV/T system, and the experimental validation was carried out to verify the numerical model. They found that the electrical efficiency is achieved as $13.98 \%$ and $13.87 \%$ numerically and experimentally respectively, and the electrical performance is improved as $6.2 \%$ and $4.8 \%$ for PV/T-PCM system based on the numerical and experimental results respectively.

Different working fluids like water, air, nanofluid and refrigerant are also used to cool the PV module. Huang and Lee (Huang and Lee, 2004) conducted long-term tests on the direct-expansion solar heat pump which adopted refrigerant as working fluid to verify the stability of the work. The total running time of their prototype is over 20000 hours, and the measured energy consumption is $0.019 \mathrm{kWh} / \mathrm{l}$ of hot water at $57{ }^{\circ} \mathrm{C}$ which is much less than traditional solar water heater. Stojanović and Akander (Stojanović and Akander, 2010) used direct-expansion heat pump for independent buildings heating and domestic hot water supply. In their system, the collector area is $42.5 \mathrm{~m}^{2}$ and heat pump power is $8.4 \mathrm{~kW}$, they measured that the actual indoor temperature is no less than $20^{\circ} \mathrm{C}$ during the testing period. Alejandro Del Amo et al. (Del Amo et al., 2019) verified the feasibility of solar PV/T heat pump through experiments. They obtained that the highest COP of the system can reach 4.62. Meanwhile, the PV module provides $67.6 \%$ of the power demand, and the payback period is 6 years.

In addition to optimize the PV/T panel, the adoption of PCM as heat storage is also a good way to stabilize the system. Kuznik et al. (Kuznik et al., 2008) adopted PCM wallboard heat storage and conducted comparative experiments. In their study, the system can effectively reduce heat loss, keep the room warm and improve indoor thermal comfort. Fiorentini et al. (Fiorentini et al., 2015) combined PCM storage with PV/T system, and the roof was used as PV/T layout location. The PCM storage adopted in their system can keep indoor comfort within a certain and potentially variable thermal comfort range. Diallo et al. (Diallo et al., 2019) proposed the PVT-LHP (PVT Loop Heat Pipe) technology employing PCM triple heat exchanger, the total 
energy efficiency of the presented system is improved by $28 \%$, and the heating COP is 2.2 times than that of a traditional PV/T system.

Owing to the instability of solar energy, traditional solar PV/T system cannot continuously and stably supply heat or power generation when solar irradiation is weak such as rainy day or winter. Consequently, the market of PV/T technology compared with PV or PT system is still very low. PV/T can adapt to the characteristics of low intensity, instability and intermittency of solar energy better if it can be combined with accumulator and heat storage. However, additional space is required to install heat storage tank, which is not suitable for use in urban areas where land resources are scarce. Therefore, in this paper, a coupling design of solar PV/T heat pump and build-in PCM heat storage is proposed and the parallel air source heat exchanger is also adopted to enhance the stability of the system. The build-in PCM heat storage used for underfloor heating is a combination of PCM and building materials, which can save more space compared to conventional PCM storage tank system. Firstly, the composition and operation modes of the system are introduced. According to the system principle, the mathematical model is established and verified, and the build-in PCM heat storage sub-system which using for residential heating is also proposed and simulated. Then the influences of different parameters on system performance are analyzed. Finally, the feasibility analysis of the system is conducted. The objective of this paper is to provide a promising method to realize stable, high efficiency, environmental friendly residential heating in high latitude area with no energy consumption from power grid. The proposed and calculated analysis of the scheme is conducive to assisting in the design and optimization of the solar PV/T heat pump system coupled with build in PCM heat storage.

\section{System description}

Fig. 1 shows the schematic diagram of the system based on solar PV/T heat pump, which is consisted of four main parts: solar PV/T heat pump module, parallel air source heat pump module, heat storage module and electrical module. The blue lines represent low temperature working fluid, and in the opposite, red lines represent high temperature. The yellow lines represent the electricity flow direction. The arrows show the working fluid direction. The system can be divided into two operating modes, which are listed as follows.

(1) Sunny day operating mode: The electricity generated by PV panel is used to drive the pumps and compressor, and the excess electricity will be recovered to the power grid or drive the air conditioning. However, the PV panel heated by solar radiation will be resulted in an increase of the temperature of PV cells. Meanwhile, the heat transferred by the PV/T collector can be absorbed by the refrigerant. Then, the superheated refrigerant vapor with low pressure is compressed by the compressor to the high temperature and pressure refrigerant vapor. The condensation heat will be absorbed and stored in the build-in PCM heat storage. The heat transferred by condensation can also be used for producing domestic hot water. The liquid refrigerant will expand through the throttle valve after condensation process, and flow into the $\mathrm{PV} / \mathrm{T}$ collector/evaporator. The heat released from the heat storage module will be used to keep the indoor temperature constant during the night.

(2) Rainy day operating mode: The system will switch to the air source heat pump mode when the solar radiation is insufficient to maintain system operation. The pumps and compressor driven by power grid are used to keep the system work. The air fan heat exchanger is adopted to absorb heat from the ambient air. The refrigerant will be heated by the air fan heat exchanger and 
compressed by compressor into high temperature and pressure vapor. The heat released by the refrigerant vapor will be transferred to the PCM or water. This mode can make full use of the valley electricity to store heat at night, and maintain the indoor temperature through the heat storage module during the day.

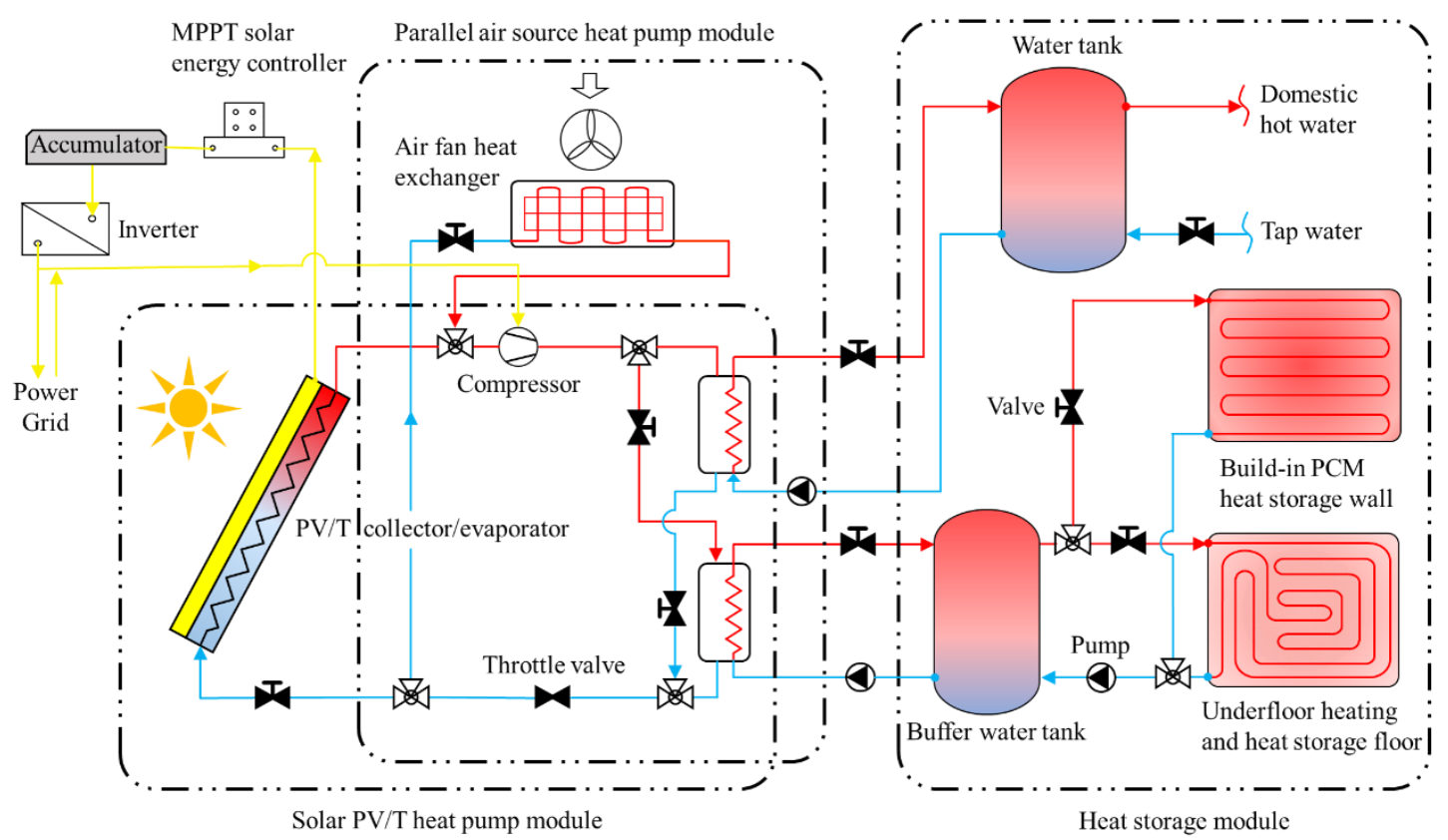

Fig. 1. Schematic of the system based on solar PV/T heat pump.

\section{Mathematical model}

The thermodynamic state points for each process are shown in Fig. 2. The solar PV/T heat pump cycle could be simplified to four components: PV/T collector/evaporator, compressor, PCM heat exchanger and throttle valve. Different temperature $(T)$ and enthalpy $(h)$ at each state point are shown in Fig. 2. $Q_{t h}(\mathrm{~W})$ is the heat transfer rate between refrigerant and the PV/T panel, $Q_{e}$ (W) is the electrical power provided by PV panel, and $Q_{P C M}(\mathrm{~W})$ is the heat transfer rate between refrigerant and phase change materials.

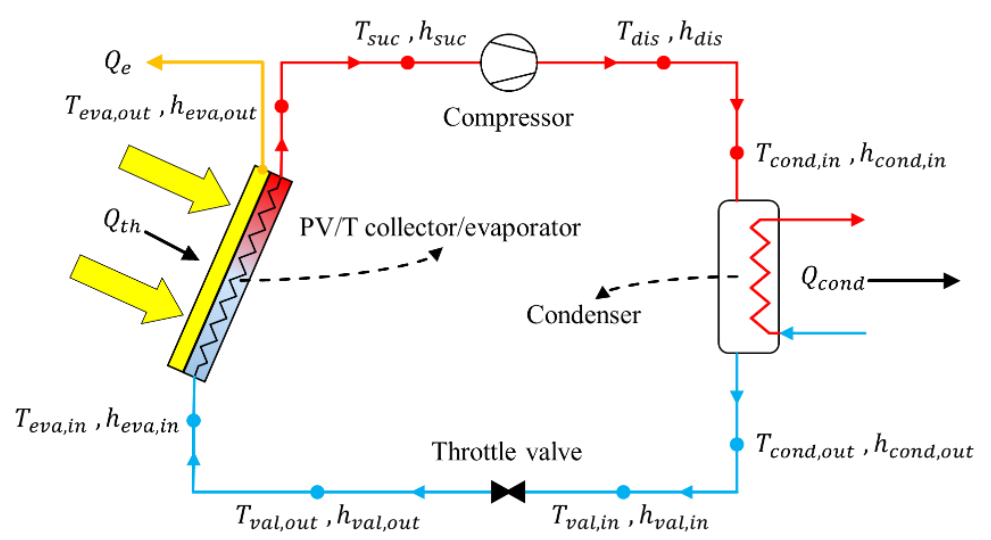

Fig. 2. The thermodynamic state points for each component.

The design parameters of the system and characteristics of different PV/T layers are listed in Table. 1. 
Table. 1. Design parameters of the system and characteristics of different PV/T layers.

\begin{tabular}{llll}
\hline Parameters & Nomenclature & Value & Unit \\
\hline Thickness of PV-glazing cover & $\delta_{g, p v}$ & 1 & $\mathrm{~mm}$ \\
Emissivity of PV-glazing cover & $\varepsilon_{c}$ & 0.84 & {$[-]$} \\
Transmissivity of PV-glazing cover & $\tau_{g, p v}$ & 0.9 & {$[-]$} \\
Thickness of PV cells & $\delta_{p v}$ & 0.3 & $\mathrm{~mm}$ \\
Emissivity of PV cells & $\varepsilon_{p}$ & 0.96 & {$[-]$} \\
Absorptance of PV cells & $a_{p}$ & 0.85 & {$[-]$} \\
Thermal conductivity of PV cells & $\kappa_{p}$ & 203 & $\mathrm{~W} / \mathrm{m} \cdot \mathrm{K}$ \\
Absorptance of PV baseboard & $a_{b}$ & 0.8 & {$[-]$} \\
Thickness of EVA grease & $\delta_{E V A}$ & 0.5 & $\mathrm{~mm}$ \\
Thermal conductivity of EVA grease & $\kappa_{E V A}$ & 0.311 & $\mathrm{~W} / \mathrm{m} \cdot \mathrm{K}$ \\
Thickness of electrical insulation & $\delta_{e i}$ & 0.5 & $\mathrm{~mm}$ \\
Thermal conductivity of electrical insulation & $\kappa_{e i}$ & 0.15 & $\mathrm{~W} / \mathrm{m} \cdot \mathrm{K}$ \\
Electrical insulation material & {$[-]$} & Tedlar & {$[-]$} \\
Packing factor & $\beta_{p}$ & 1 & {$[-]$} \\
Length of PV/T collector/evaporator & $L$ & 2.0 & $\mathrm{~m}$ \\
Width of PV/T collector/evaporator & $W$ & 1.0 & $\mathrm{~m}$ \\
Area of the PV/T collector/evaporator & $A$ & 2.0 & $\mathrm{~m}$ \\
Thermal conductivity of roll-bond panel & $\kappa_{r b}$ & 151 & $\mathrm{~W} / \mathrm{m} \cdot \mathrm{K}$ \\
Thickness of roll-bond panel pipe & $\delta_{r b}$ & 1 & $\mathrm{~mm}$ \\
Refrigerant type & $r e f$ & $\mathrm{R} 134 \mathrm{~A}$ & {$[-]$} \\
\hline
\end{tabular}

\subsection{Model of PV/T collector/evaporator}

The heat absorbed by the PV/T panel is expressed as follows:

$$
Q_{a b s}=\left(1-\eta_{e}\right) \cdot A \cdot I \cdot \tau_{g, p v} \cdot\left[\alpha_{p} \cdot \beta_{p}+\alpha_{b} \cdot\left(1-\beta_{p}\right)\right]
$$

where $A$ is the collector area of the PV/T panel $\left(\mathrm{m}^{2}\right) ; I$ is the solar radiation intensity $\left(\mathrm{W} / \mathrm{m}^{2}\right) ; \tau_{g, p v}$ is the transmittances of the PV-glazing cover; $a_{p}$ and $a_{b}$ are the absorption ratios of the PV cells and its baseboard, respectively; $\beta_{p}$ is the packing factor of PV cells; $\eta_{e}$ is the PV cells' efficiency, calculated by (Huide et al., 2017):

$$
\eta_{e}=\eta_{r c} \cdot\left[1-\beta_{p v} \cdot\left(T_{p}-T_{r c}\right)\right]
$$

$\eta_{r c}$ is the reference photovoltaic efficiency value of PV cells at $T_{r c}=298 \mathrm{~K}, \eta_{r c}=0.18 ; \beta_{p v}$ is the temperature coefficient (1/K) of PV cell efficiency, $\beta_{p v}=0.0045$ (Huide et al., 2017).

The heat loss, physical model of the PV/T collector/evaporator, the front view of PV/T panel on the roof and the roll-bond panel which encapsulated in the PV/T panel are shown in Fig. 3. Fig. 3 shows the heat loss and physical model of PV/T panel which has a multi-layer structure, the heat loss of PV/T panel consists of two parts: (1) heat transfer from PV cells to PV-glazing cover; (2) heat transfer from PV-glazing cover to ambient air.The thermal resistances of the PV/T module are shown in Fig. 3(a), and all consist of convection and radiation thermal resistance in different part. 


$$
Q_{L}=U_{L} \cdot A \cdot\left(T_{p}-T_{a}\right)
$$

168 where $T_{p}$ and $T_{a}$ are the temperature of PV cells and ambient air, respectively. $U_{L}$ is the overall heat loss coefficient which can be written as:

$$
U_{L}=\left[1 /\left(h_{c v, p-c}+h_{r d, p-c}\right)+1 /\left(h_{c v, c-a}+h_{r d, c-a}\right)\right]^{-1}
$$

$h_{c, p-c}$ and $h_{r d, p-c}$ are the convective and radiative heat-transfer coefficients between PV cells and glass cover; $h_{c v, c-a}$ and $h_{r d, c-a}$ are the convective and radiative heat-transfer coefficients between glass cover and ambient.

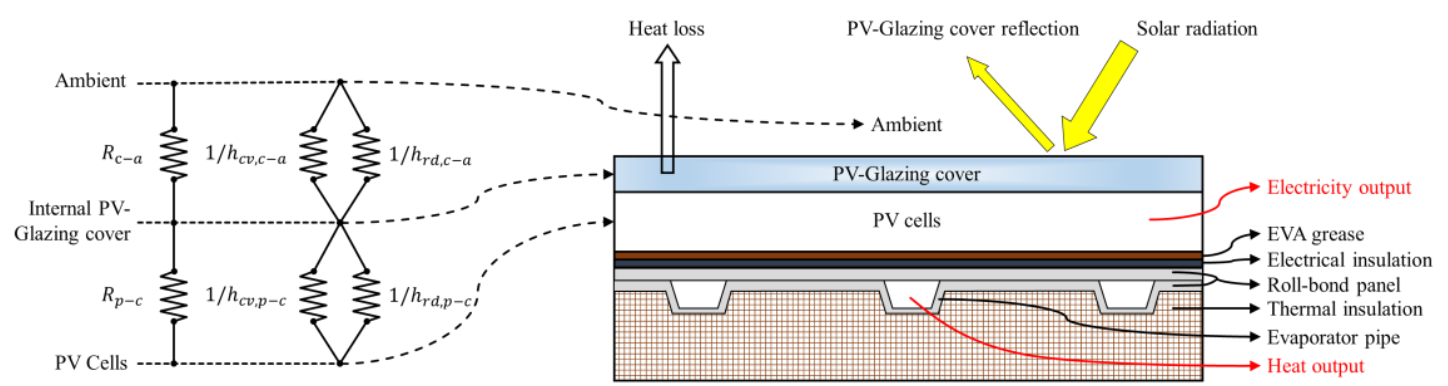

Fig. 3. Heat loss and physical model of PV/T collector/evaporator.

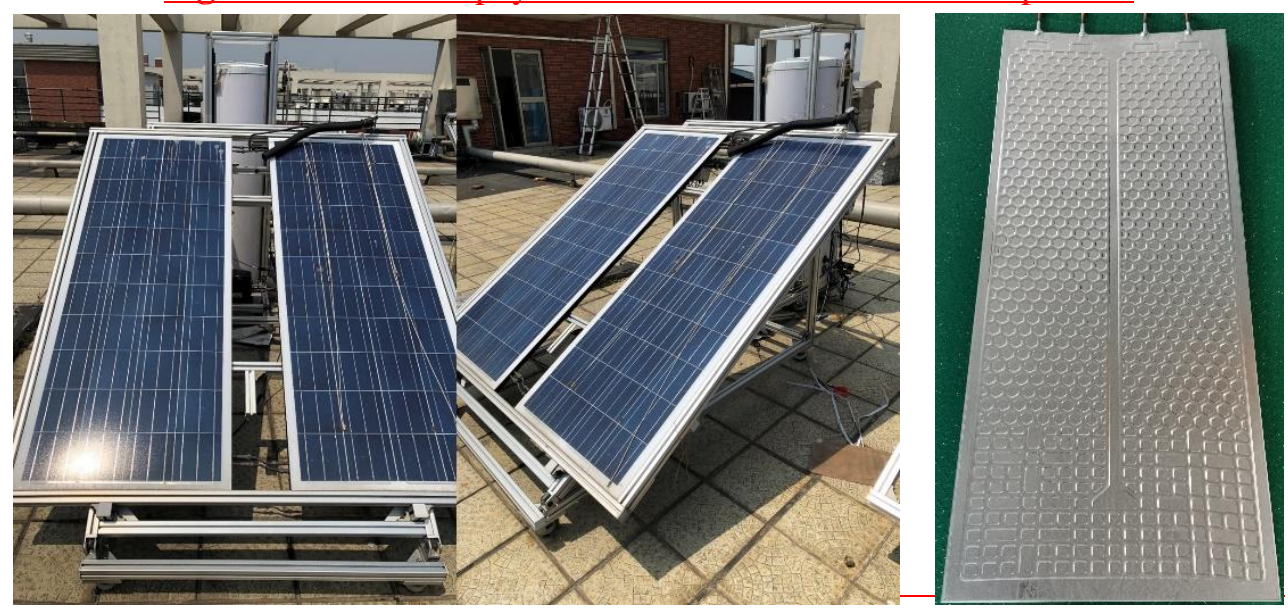

(c) (d)

Fig. 3. (a) Heat loss of the PV/T collector/evaporator. (b) Physical model of the PV/T collector/evaporator. (c) Front view of PV/T panel on the roof. (d) Roll bond panel.

The overall electricity output power of PV cells is given as:

$$
Q_{e}=A \cdot I \cdot \tau_{g, p v} \cdot \alpha_{p} \cdot \beta_{p} \cdot \eta_{e}
$$

Under the steady-state condition, the heat transfer rate delivered by the module equals the rate of the absorbed heat minus the overall heat loss, expressed as:

$$
Q_{t h}=Q_{a b s}-Q_{L}
$$

The total useful solar heat received by the PV/T collector/evaporator is expressed as:

$$
Q_{u}=F_{R} \cdot A \cdot I \cdot \tau_{g, p v} \cdot\left[\alpha_{p} \cdot \beta_{p}+\alpha_{b} \cdot\left(1-\beta_{p}\right)\right]
$$

where $F_{R}$ is the $\mathrm{PV} / \mathrm{T}$ collector thermal efficiency factor, can be defined as (Diallo et al., 2019): 


$$
F_{R}=\left(1-\eta_{e}\right) \cdot \frac{1 / U_{L}}{L \cdot W / N_{r b} \cdot\left\{1 /\left(L \cdot U_{L}-\left[\left(W / N_{r b}-L_{r b}\right) F_{r b}+L_{r b} /\left(1+R_{p v} \cdot U_{L}\right)\right]\right)+\sum_{1}^{5} R_{i}\right\}}
$$

190

$N_{r b}$ is the equivalent number of roll-bond panel pipe; $L_{r b}$ is the equivalent length of roll-bond panel pipe; $\Sigma R i$ is the overall thermal resistance from the PV cells to the PCM; $F_{r b}$ is the efficiency of the roll-bond panel which encapsulated in the backside of the PV/T panel which can be defined as (Diallo et al., 2019):

$$
F_{r b}=\tanh \left[\sqrt{\frac{U_{L}}{\left(k_{r b} \delta_{r b}\left(1+R_{p v} U_{L}\right)\right)}}\left(W / N_{r b}-L_{r b}\right) / 2\right] /\left(\sqrt{\frac{U_{L}}{\left(k_{r b} \delta_{r b}\left(1+R_{p v} U_{L}\right)\right)}}\left(W / N_{r b}-L_{r b}\right) / 2\right)
$$

$\kappa_{r b}$ is the thermal conductivity of roll-bond panel; $\delta_{r b}$ is the thickness of the roll-bond panel pipe; $R_{p v}$ is the thermal resistance of PV cells.

The thermal resistances of the PV/T system and heat transfer along the system are shown in Fig. 4.

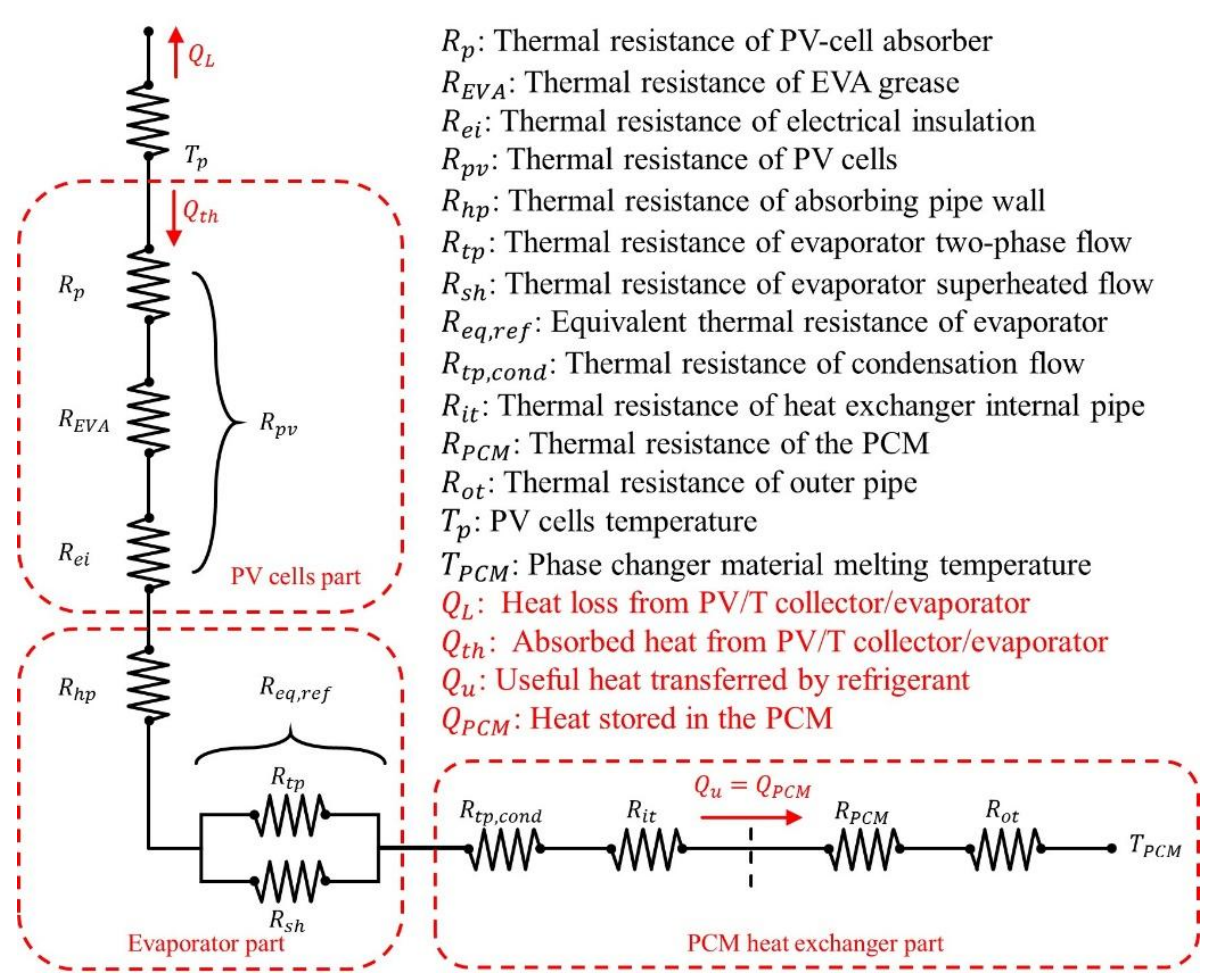

Fig. 4. Thermal resistances of the PV/T system and heat transfer along the system.

Heat transfer between PV module and heat pipe is a conventional one dimensional heat conduction process and its associated thermal resistance is:

$$
R_{p v}=\delta_{p} / k_{p}+\delta_{E V A} / k_{E V A}+\delta_{e i} / k_{e i}
$$

Superheated region and two-phase region existed in the refrigerant side of the PV/T collector/evaporator. The equivalent thermal resistance of the two different regions can be calculated as (P. Hartnett and M. Rohsenow, 1973):

$$
R_{e q, r e f}=\left(1 / R_{t p}+1 / R_{s h}\right)^{-1}
$$




\subsection{Model of build-in PCM heat storage}

All the heat gained by the build-in PCM heat storage is transferred by the PCM heat exchanger. The heat store rate in the PCM and concrete is expressed as follows:

$$
Q_{P C M}+Q_{\text {conc }}=m_{r e f}^{\bullet} \cdot\left(h_{d i s}-h_{i n}\right)
$$

The PCM melting rate is calculated by:

$$
\dot{m}=Q_{P C M} / \triangle H_{P C M}
$$

where $\triangle H_{P C M}$ is the latent heat of the PCM $(\mathrm{kJ} / \mathrm{kg})$.

Fig. 5 shows the phase change temperature of 15 kinds of phase change materials including organic/inorganic/eutectic compounds materials. According to L.F. Cabeza et al. (Cabeza et al., 2011), the recommendation phase change temperature range for underfloor heating is between $30{ }^{\circ} \mathrm{C}$ to $40{ }^{\circ} \mathrm{C}$. There are five kinds of PCM that have phase change temperature in this range:

Paraffin wax, $\mathrm{CaCl}_{2} \cdot\left(\mathrm{H}_{2} \mathrm{O}\right)_{6}-\mathrm{MgCl}_{2} \cdot\left(\mathrm{H}_{2} \mathrm{O}\right)_{6}$, Calcium chloride hexahydrate, Sodium sulphate decahydrate, Sodium phosphate dibasic dodecahydrate.

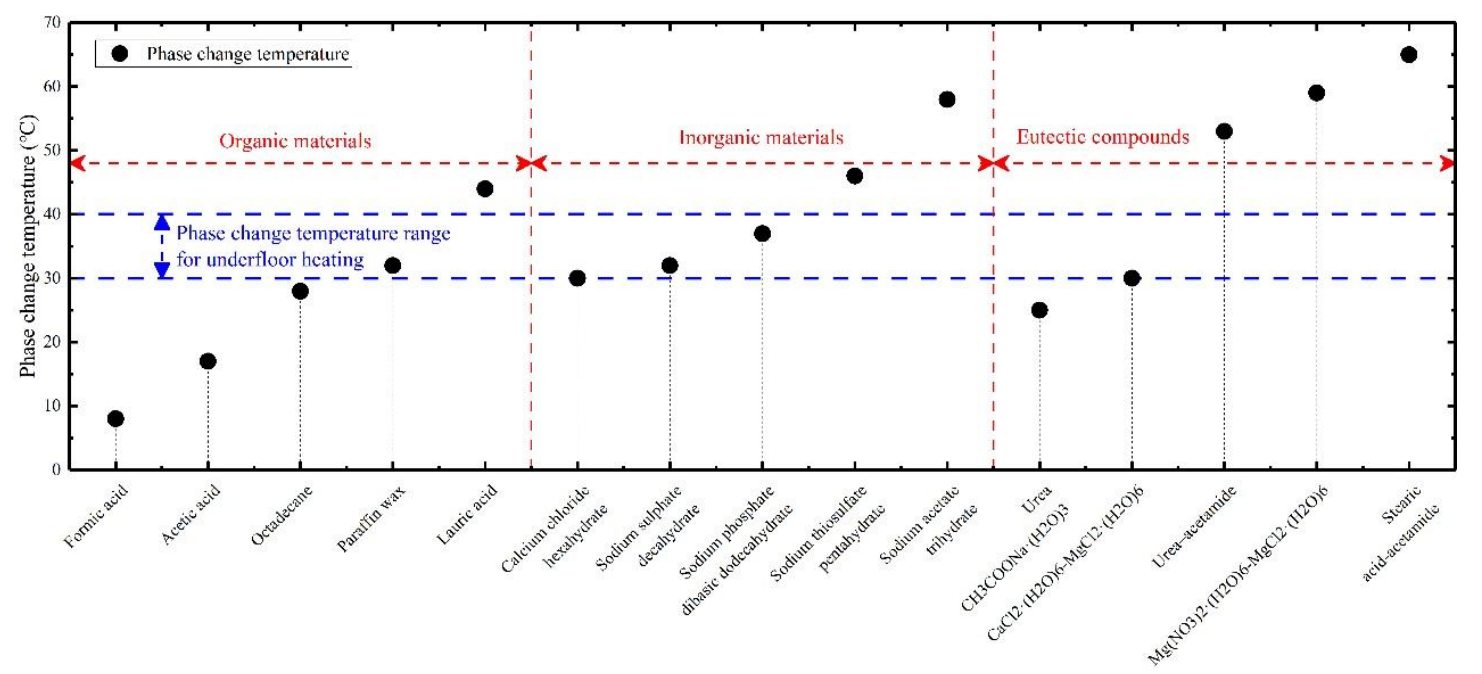

Fig. 5. Phase change temperature of 15 kinds of PCM including Organic/Inorganic/Eutectic compounds materials.

The variation curve of floor temperature with phase change temperature and the comparison of three indices including thermal conductivity, latent heat and price (Pereira da Cunha and Eames, 2016) of above five kinds of PCM are shown in Fig. 6. These five materials have different phase change temperature which all in the recommendation temperature range for underfloor heating. The ideal material should have a higher thermal conductivity and latent heat while the price is low. In order to evaluate these five materials, the graph of ideal material is also plotted in Fig. 6. The organic and eutectic compounds phase change materials have a higher price than inorganic materials while the thermal conductivity and latent heat are lower. Moreover, the larger of the overlap area in Fig. 6 between each material and ideal material, the better of the material performance. As shown in Fig. 6, Sodium phosphate dibasic dodecahydrate has the largest overlap area, thus, it is used in the simulation of build-in PCM heat storage unit. 


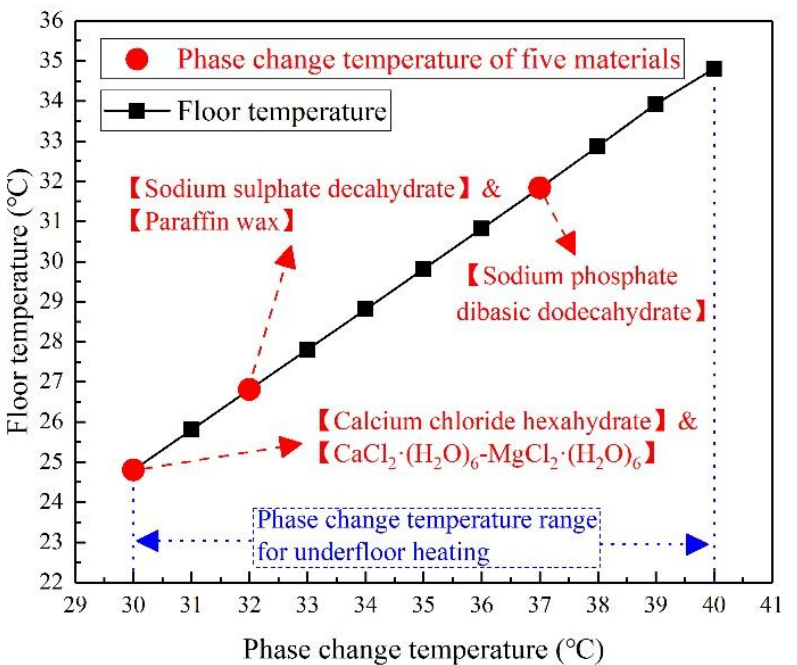

(a)

Thermal conductivity $(\mathrm{W} / \mathrm{m} \cdot \mathrm{K})$

Price $(£ / \mathrm{m} 3)$

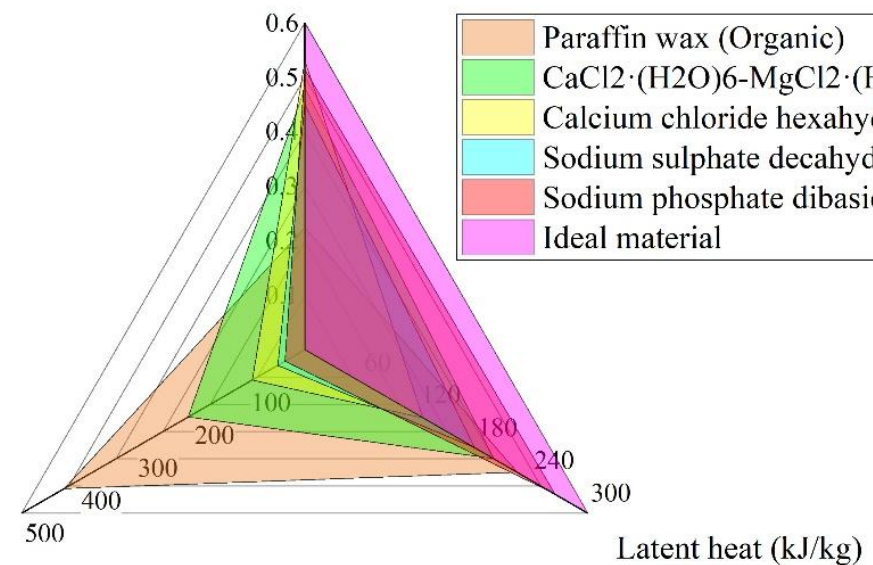

(b)

Fig. 6. (a) Variation curve of floor temperature with phase change temperature. (b) Thermal conductivity/Latent heat/Price comparison of six kinds of materials including ideal material.

Fig. 7 illustrates the structure and cross-section view of a build-in PCM heat storage unit which is the component of underfloor heating module. The phase change materials (Sodium phosphate dibasic dodecahydrate) are placed in the outer tube of a double-wall tube which can store heat during the day and release latent heat at night. The floor temperature range of the underfloor heating is $20^{\circ} \mathrm{C}$ to $35^{\circ} \mathrm{C}$ for residential applications. The phase change materials should have a melting temperature lying in the practical range of operation, melt congruently with minimum subcooling and be chemically stable, low in cost, nontoxic and non-corrosive. Moreover, as shown in Fig. 8(b), the outer tube of the build in PCM heat storage is around $37^{\circ} \mathrm{C}$ when the eireulating water temperature is $40^{\circ} \mathrm{C}$. Thus, it is reasonable to choose a phase change materiat which melting point is around $37^{\circ} \mathrm{C}$. The cross section view of the build in heat storage unit is shown in Fig. 7(b).Polystyrene board and foam concrete are used as thermal insulation and building materials, respectively. The hot water which produced by solar PV/T heat pump module is pumped into the pipe of underfloor heating to keep the indoor temperature steady. The properties of PCM (Jankowski and McCluskey, 2014) and concrete as well as underfloor heating 
working conditions are listed in Table. 2.

260

261

262

263

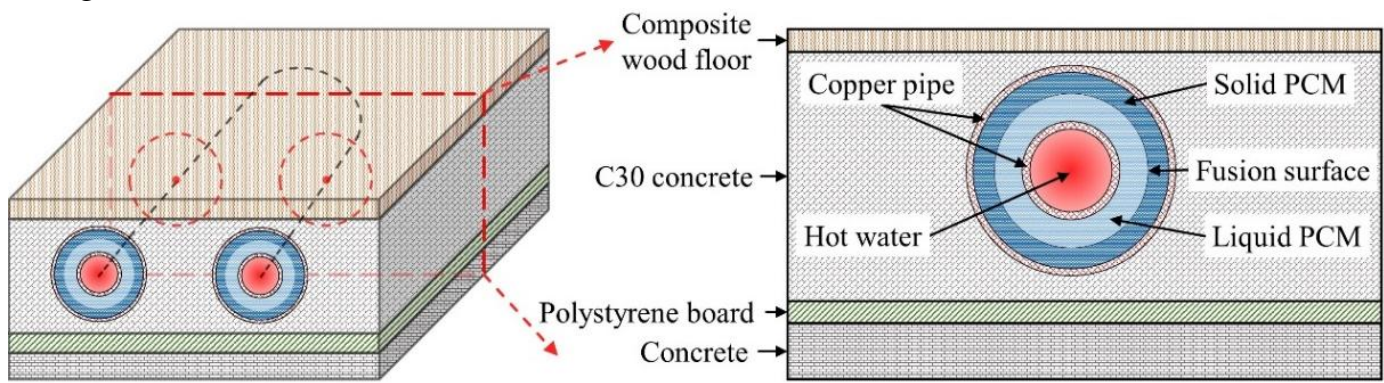

Fig. 7. Structure and cross-section view of the build-in PCM heat storage unit.

Table. 2. Properties of PCM and concrete as well as underfloor heating working conditions.

\begin{tabular}{|c|c|c|c|}
\hline Parameters & Nomenclature & Value & Unit \\
\hline Type of PCM & {$[-]$} & $\mathrm{Na}_{2} \mathrm{HPO}_{4} \cdot 12 \mathrm{H}_{2} \mathrm{O}$ & {$[-]$} \\
\hline Latent heat of PCM & $\Delta H_{P C M}$ & 265 & $\mathrm{~kJ} / \mathrm{kg}$ \\
\hline Density of PCM & $\rho_{P C M}$ & 1507 & $\mathrm{~kg} / \mathrm{m}^{3}$ \\
\hline Temperature of transition of PCM & $T_{m e l}$ & 37 & ${ }^{\circ} \mathrm{C}$ \\
\hline $\begin{array}{l}\text { Specific heat at constant pressure of } \\
\text { PCM }\end{array}$ & $C_{p-P C M}$ & 1.69 & $\mathrm{~kJ} / \mathrm{kg} \cdot \mathrm{K}$ \\
\hline Thermal conductivity of PCM & $\kappa_{P C M}$ & 0.514 & $\mathrm{~W} / \mathrm{m} \cdot \mathrm{K}$ \\
\hline Thermal conductivity of copper coil & $\kappa_{C}$ & 397 & $\mathrm{~W} / \mathrm{m} \cdot \mathrm{K}$ \\
\hline Type of concrete & {$[-]$} & $\mathrm{C} 30$ & {$[-]$} \\
\hline $\begin{array}{l}\text { Specific heat at constant pressure of } \\
\text { concrete }\end{array}$ & $C_{p \text {-conc }}$ & 0.97 & $\mathrm{~kJ} / \mathrm{kg} \cdot \mathrm{K}$ \\
\hline Thermal conductivity of concrete & $\kappa_{c o n}$ & 1.6 & $\mathrm{~W} / \mathrm{m} \cdot \mathrm{K}$ \\
\hline Density of concrete & $\rho_{\text {conc }}$ & 2300 & $\mathrm{~kg} / \mathrm{m}^{3}$ \\
\hline Thickness of the concrete & $\delta_{c o n}$ & 0.13 & $\mathrm{~m}$ \\
\hline Thickness of the wood floor & $\delta_{\text {floor }}$ & 0.01 & $\mathrm{~m}$ \\
\hline Volume flow rate of circulating water & $V_{c w}$ & 2.5 & $\mathrm{~m}^{3} / \mathrm{h}$ \\
\hline
\end{tabular}

264

265

Fig. 8 (a $\sim$ c) presents the simulation results of heat transfer in build-in PCM heat storage unit at different time which carried out by software of Ansys Fluent 17.0. The thermal conductivity of the heat transfer between the coil and PCM has been considered in the setup of the boundary conditions. Thus, the boundary conditions of inner and outer tube have been set as "coupled" in Ansys Fluent 17.0 which means the solution of heat transfer process would be carried out through the coupled method in the program. The initial temperature of the heat storage unit is $15^{\circ} \mathrm{C}$, and the underfloor heating can reach above $30^{\circ} \mathrm{C}$ after 39 hours when the circulating water is $40^{\circ} \mathrm{C}$. As shown in Fig. 8(md), the floor temperature increases with time and reaches $25{ }^{\circ} \mathrm{C}$ in the first 12 hours which has $10^{\circ} \mathrm{C}$ difference with the ambient. The changing curve mountains rapidly in the initial stage and becomes steady after 39 hours, the build-in PCM heat storage would supply heat to indoor area and maintain the room temperature. 
276

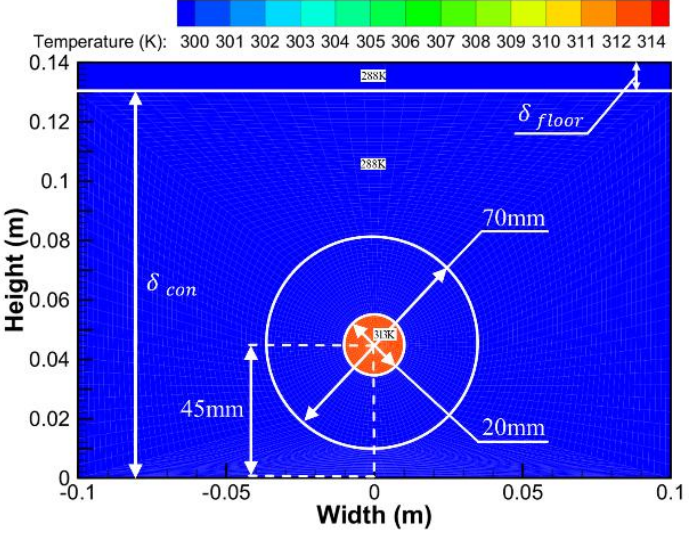

(a) Initial stage

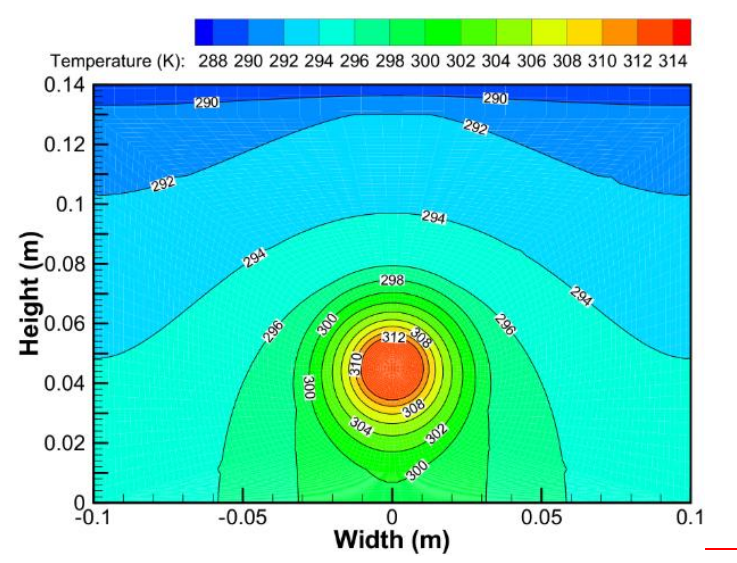

(c) 3 hours

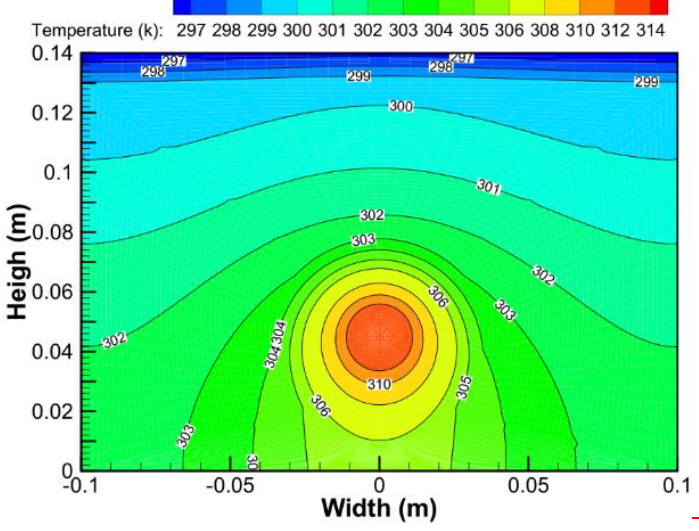

(e) 9 hours

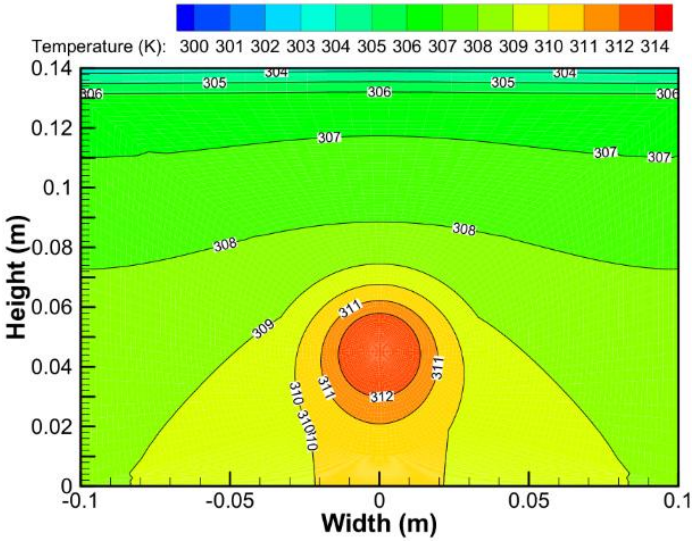

(b) Steady stage

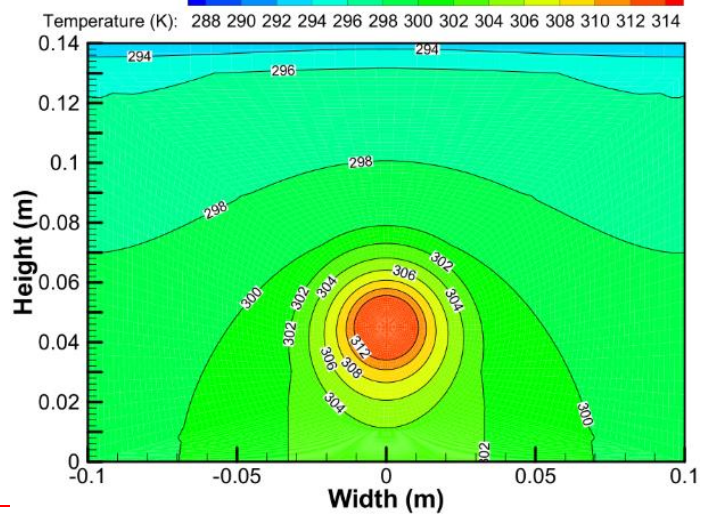

(d) 6 hours

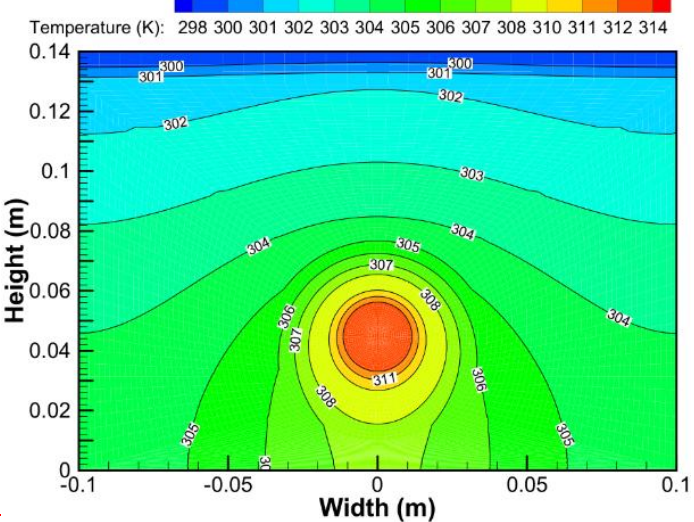

(f) 12 hours 

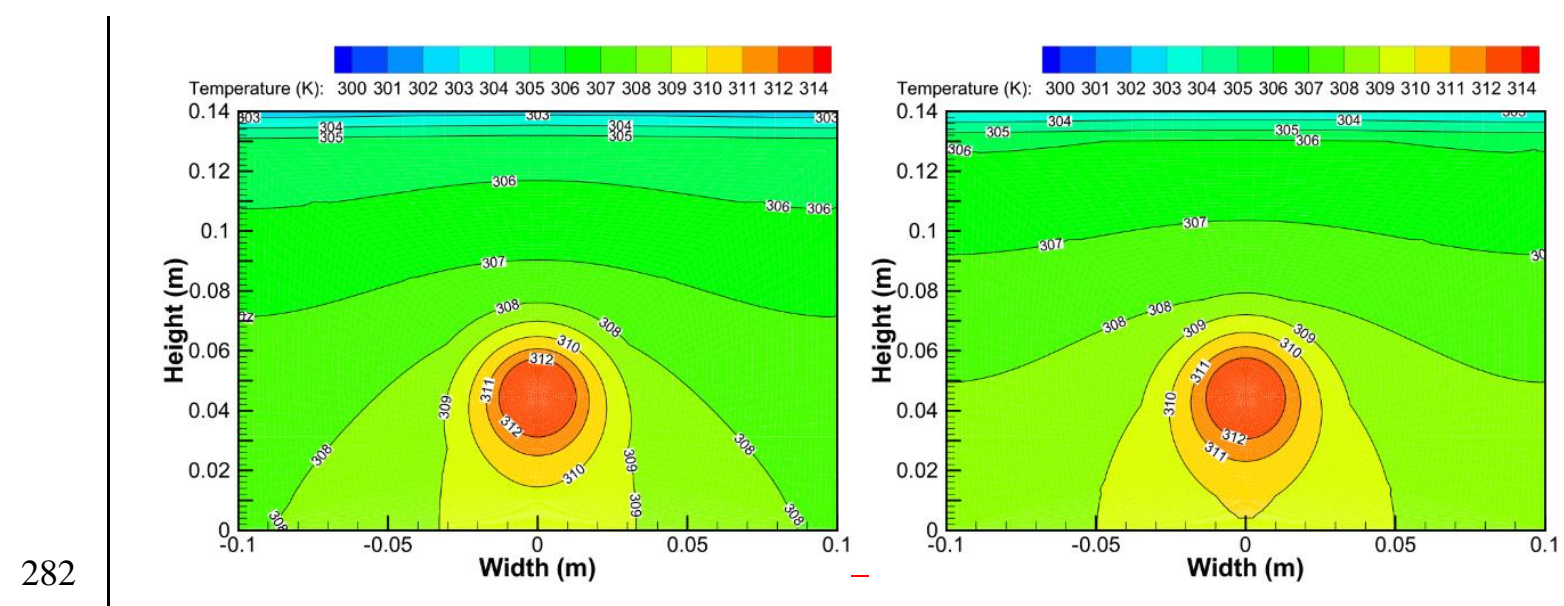

(g) 24 hours

(h) 30 hours
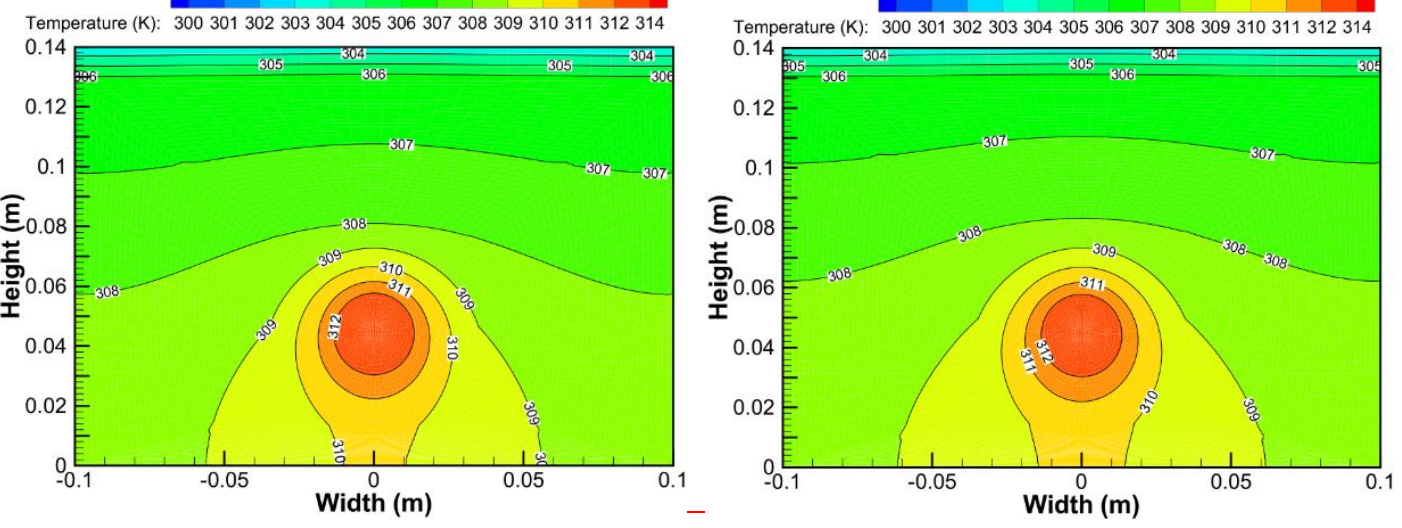

(i) 33 hours

(j) 36 hours
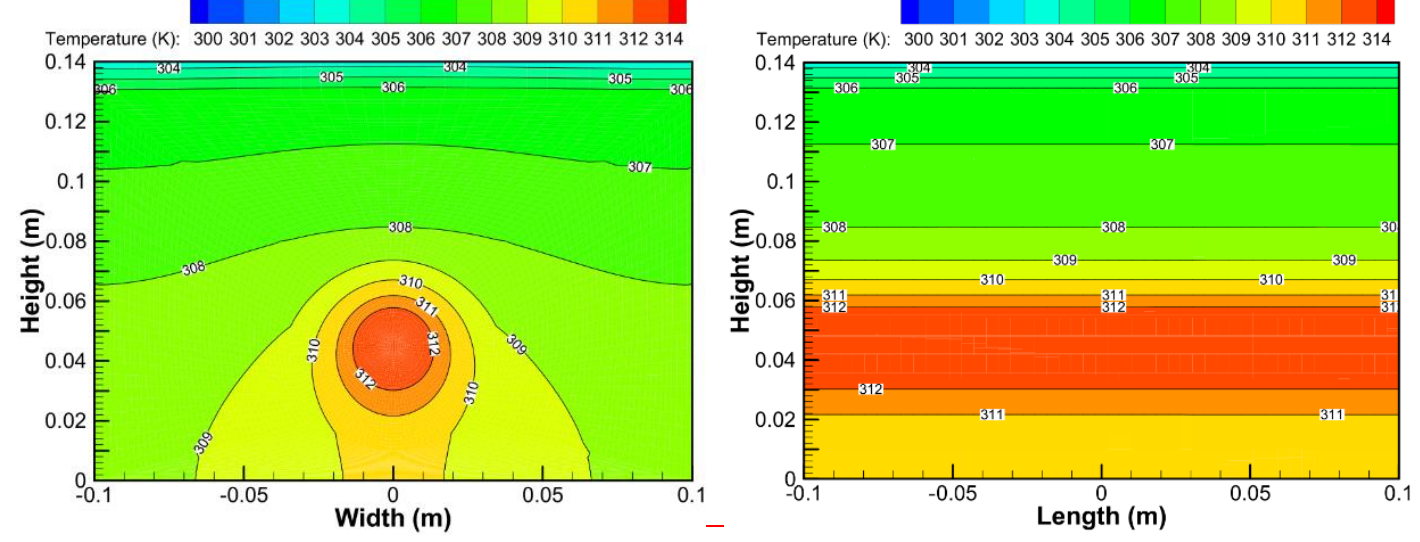

287

(k) 39 hours

(1) Cross-section view at the width of 0 ( 39 hours) 


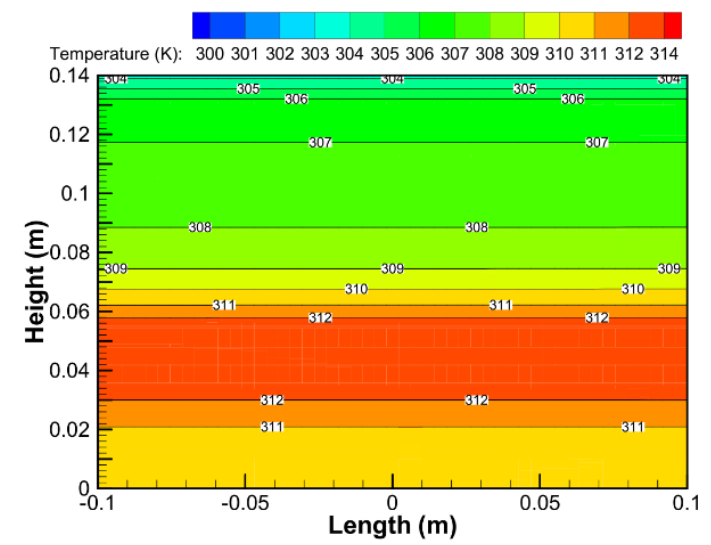

(c) Cross-section view at the width of 0 (steady stage)

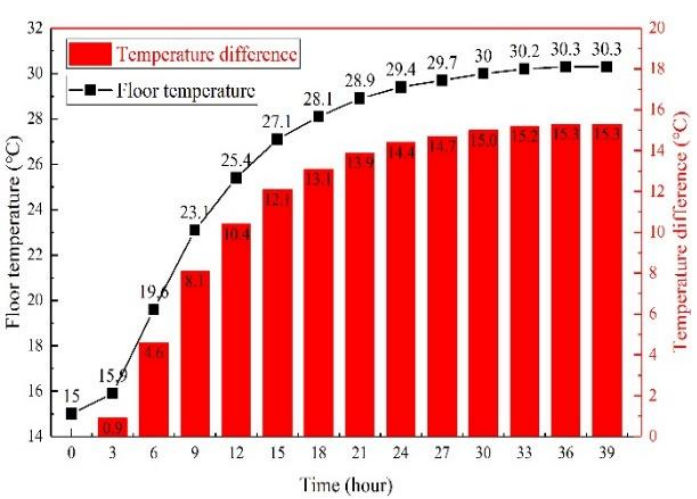

(d)

Fig. 8. (a-1) Cross section temperattre contour of the build in PCM heat storage unit at different time. (m) Variation curve of floor temperature and temperature difference between floor and ambient.

Fig. 8. (a c) Cross-section temperature contour of the build-in PCM heat storage unit at initial and steady stage. (d) Variation curve of floor temperature and temperature difference between floor and ambient.

Fig. 9 shows the variation curves of circulating water temperature and floor temperature with the length of circulating water tube. The temperature of circulating water would decrease from $40{ }^{\circ} \mathrm{C}$ (inlet) to $32.5^{\circ} \mathrm{C}$ (outlet) while the floor temperature varies from $30.4{ }^{\circ} \mathrm{C}$ to $22.9^{\circ} \mathrm{C}$. This figure also presents the three temperature range of underfloor heating which can divided into three categories: Temperature range of no person staying area $\left(29^{\circ} \mathrm{C}-35^{\circ} \mathrm{C}\right)$, Temperature range of short-time staying area $\left(25^{\circ} \mathrm{C}-29^{\circ} \mathrm{C}\right)$ and Temperature range of long-time staying area $\left(20^{\circ} \mathrm{C}-25^{\circ} \mathrm{C}\right)$. For a typical family, the heating area is about $100 \mathrm{~m}^{2}$-which needs about 150 meters of underfloor heating tube (circulating water tube). As shown in Fig. 9, the first 30 meters tube can arrange in the no person staying area (storage room etc.) while 30 to 110 meters tube can arrange in the short time staying area (living room, kitchen etc.), and 110 to 150 meters tube can arrange in the long time staying area (bedroom etc.). Therefore, when using build-in PCM heat storage as underfloor heating, the system could meet the heat demand of users and keep indoor temperature steady.

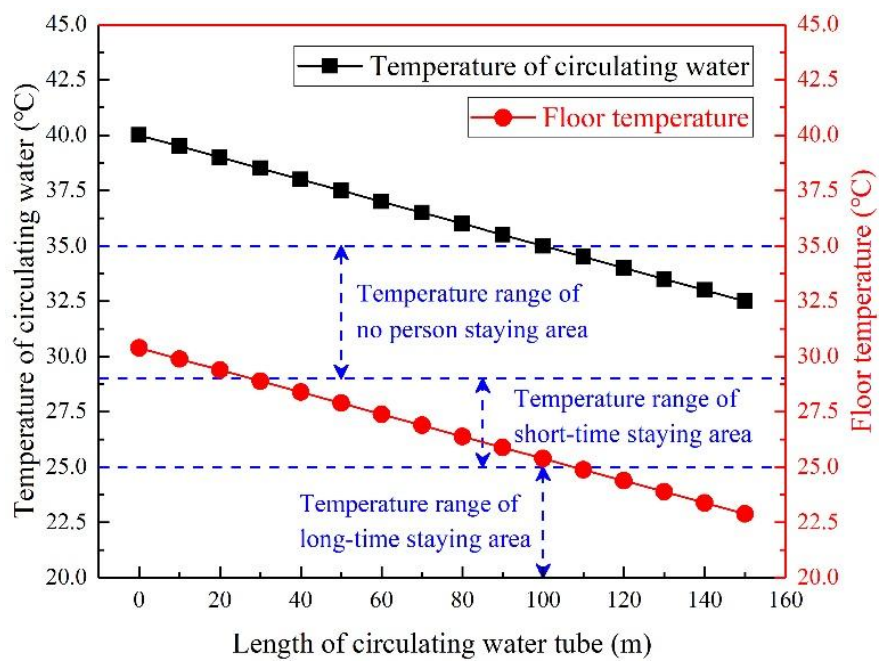


Fig. 9. Variation curves of circulating water temperature and floor temperature with the length of circulating water tube.

\subsection{Model of compressor}

The refrigerant mass flow rate $m_{r e f}^{\bullet}$ could be calculated by (Ma, 2013)

$$
m_{r e f}^{\bullet}=\lambda \cdot V_{t h} / v_{\text {suc }}
$$

where the $\lambda$ is the compressor volumetric efficiency, $V_{t h}$ is the theoretical displacement volume of compressor $\left(\mathrm{m}^{3}\right), v_{\text {suc }}$ is the specific volume of the refrigerant in the suction period $\left(\mathrm{m}^{3} / \mathrm{kg}\right)$.

The power consumption of compressor is written as:

$$
P_{\text {com }}=m_{r e f} \cdot\left(h_{\text {dis }}-h_{\text {suc }}\right) / \eta_{\text {ele }}
$$

where $\eta_{e l e}$ is the efficiency of the compressor which can be expressed by (Ma, 2013):

$\eta_{\text {ele }}=-0.17938+0.87501 \frac{p_{d i s}}{p_{\text {suc }}}-0.30014\left(\frac{p_{d i s}}{p_{\text {suc }}}\right)^{2}+0.04135\left(\frac{p_{d i s}}{p_{s u c}}\right)^{3}-0.00206\left(\frac{p_{d i s}}{p_{s u c}}\right)^{4}$

The refrigerant vapor through compressor is isentropic, thus the equation can be expressed by:

$$
T_{d i s} / T_{s u c}=\left(p_{d i s} / p_{s u c}\right)^{(\chi-1) / \chi}
$$

where the $\chi$ is the polytropic index of refrigerant. $h_{d i s}$ is the enthalpy of the vapor after compressed $(\mathrm{kJ} / \mathrm{kg}), h_{s u c}$ is the enthalpy of the vapor before compressed $(\mathrm{kJ} / \mathrm{kg})$.

The heat of refrigerant absorbed from the PV/T collector/evaporator equal to $Q_{u}$ :

$$
m_{\mathrm{ref}} \cdot\left(h_{\mathrm{eva}, \mathrm{out}}-h_{\mathrm{eva}, \mathrm{in}}\right)=Q_{u}=Q_{\mathrm{th}}
$$

\subsection{Definition of the system performance}

The COP (Coefficient of Performance) of the system can be defined as the ratio of overall heat output of system and power consumption of the compressor as following (R. Turns, 2006)

$$
\mathrm{COP}=m_{\text {ref }} \cdot\left(h_{\text {cond }, \text { in }}-h_{\text {cond }, \text { out }}\right) / P_{\text {com }}
$$

The $\eta_{t h}$ is the PV/T collector/evaporator's thermal efficiency, which can be defined as:

$$
\eta_{t h}=Q_{t h} /(A \cdot I)
$$

The $\eta_{e}$ is the PV cells electrical efficiency which can be defined as:

$$
\eta_{e}=Q_{e} /(A \cdot I)
$$

The $\eta_{\text {ove }}$ is the overall efficiency which can be defined as:

$$
\eta_{\text {ove }}=\left(Q_{\text {cond }}+Q_{e}\right) /(A \cdot I)
$$


The numerical simulation procedure of the system is shown in Fig. 10 to predict the system performance using the software of MATLAB. The solution steps are as flows:

(1) Input all the environmental parameters, such as solar radiation intensity, wind speed, ambient temperature, etc.

(2) Input the system design parameters and operation parameters, such as collector area, packing factor, collector slop, transmissivity of external glass cover, PV-glazing cover, thickness of each layer, etc.

(3) Assume the temperature of PV cells $T_{p}$.

(4) Calculate the overall heat loss rate $Q_{L}$, and the PV electrical output power $Q_{e}$.

(5) Calculate the thermal energy gain rate through PV/T collector/evaporator $Q_{t h}$, and the useful heat transfer rate by refrigerant $Q_{u}$.

(6) Calculate $\left(Q_{t h^{-}} Q_{u}\right) / Q_{t h}$. If $\left|\left(Q_{t h^{-}} Q_{u}\right) / Q_{t h}\right|<0.1 \%$, the system achieves the heat balance and move to next step.

(7) Input the superheat degree $T_{s h}$.

(8) Assume the compressor discharge pressure $P_{\text {dis }}$.

(9) Calculate the PV/T collector/evaporator inlet enthalpy $h_{\text {eva,in }}$ and the PCM heat exchanger outlet enthalpy $h_{\text {cond,out }}$. If $\left|\left(h_{\text {eva, in }}-h_{\text {cond,out }}\right) / h_{\text {cond,out }}\right|<0.1 \%$, the system achieves the pressure balance and move to next step.

(10)Calculate the COP, PCM melting rate $\dot{m}$, thermal efficiency $\eta_{t h}$, electrical efficiency $\eta_{e}$, and overall efficiency $\eta_{\text {ove }}$.

(11)Results output, and stop the program. 


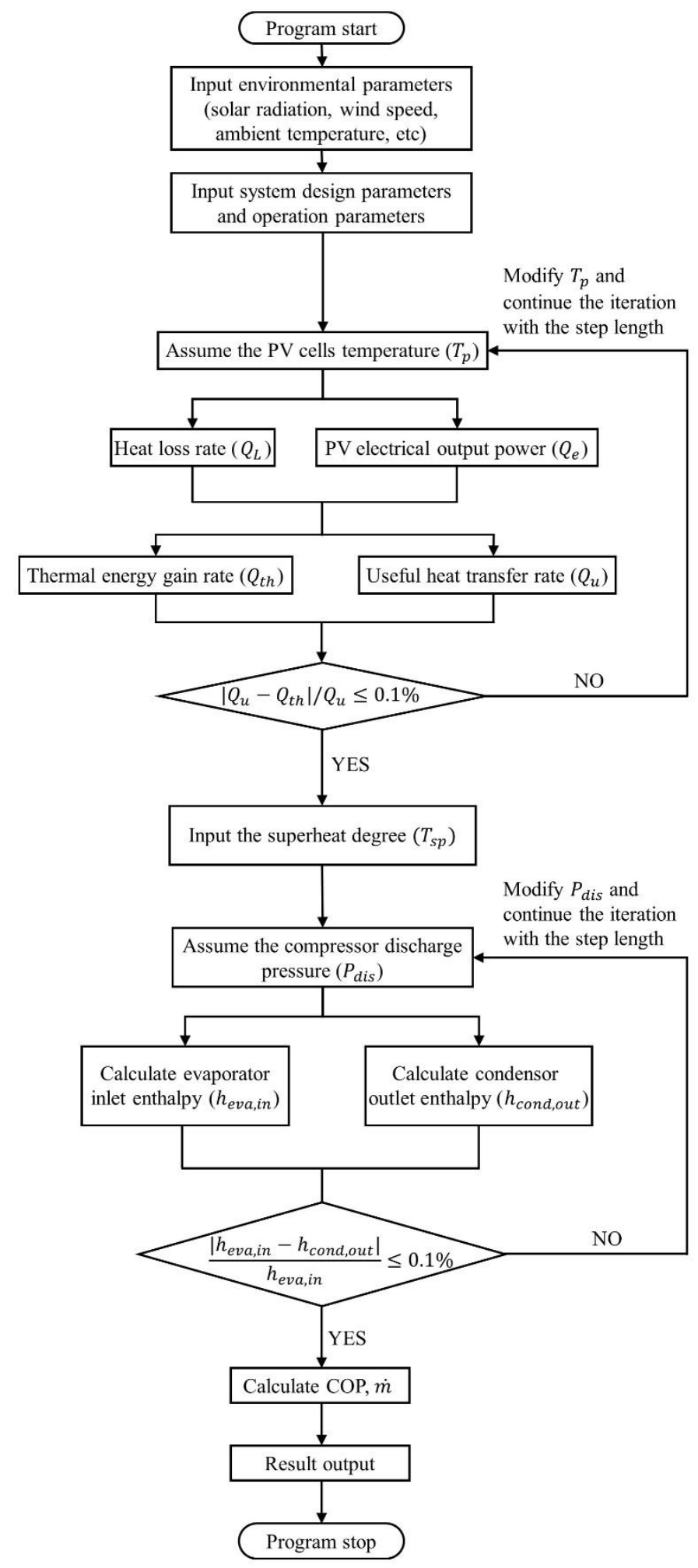

Fig. 10. Numerical solution procedure of the system.

\section{Validation of the model}

To ensure the reliability of the mathematic model, the simulation results should be compared with the experimental results. The experimental parameters used in the simulation are listed in Table. 3. 
Table. 3. Experimental parameters (Zhou et al., 2019).

\begin{tabular}{llll}
\hline Parameters & Nomenclature & Value & Unit \\
\hline Thickness of glass cover & $\delta_{g}$ & 3.2 & $\mathrm{~mm}$ \\
Thickness of air gap & $\delta_{\text {air }}$ & 35 & $\mathrm{~mm}$ \\
Thickness of PV-glazing cover & $\delta_{g, p v}$ & 1 & $\mathrm{~mm}$ \\
Thickness of PV cells & $\delta_{p v}$ & 0.2 & $\mathrm{~mm}$ \\
Thickness of EVA adhesive film & $\delta_{E V A}$ & 0.4 & $\mathrm{~mm}$ \\
Thickness of electrical insulation & $\delta_{e i}$ & 0.5 & $\mathrm{~mm}$ \\
Length of PV/T & $L$ & 3.0 & $\mathrm{~m}$ \\
Width of PV/T & $W$ & 1.6 & $\mathrm{~m}$ \\
Wind speed & $v_{\text {wind }}$ & 1.5 & $\mathrm{~m} / \mathrm{s}$ \\
Ambient temperature & $T_{a}$ & 298.5 & $\mathrm{~K}$ \\
Refrigerant type & $r e f$ & $\mathrm{R} 22$ & {$[-]$} \\
Packing factor & $\beta_{p}$ & 0.64 & {$[-]$} \\
\hline
\end{tabular}

The comparison results of heating COP are presented in Fig. 11(a), the operating conditions are refer from Zhou et al.(Zhou et al., 2019). Under the same system components_(PV/T collector/evaporator, compressor, condenser, expansion valve, water tank), the simulation results are in good agreement with the experimental results. Heating COP of the PV/T system increases in the first 15 minutes because the water in the tank still in the low temperature range. Thus, the temperature differences between the refrigerant fluid and water remains large in the condenser leading to a high heat transfer efficiency. However, the heat transfer efficiency of the condenser would be decreased when the temperature of the inlet water rises up during the operation of the whole system. That is the reason of the reduction of heating COP after 15 minutes. The average error of heating COP is $2.84 \%$ while the maximum error is $5.12 \%$. Fig. 1211 (b) presents the experimental and simulation results of the photovoltaic efficiency. The maximum photovoltaic efficiency is $10.11 \%$ while the minimum is $8.09 \%$, but all the experimental photovoltaic efficiencies fluctuate around $9.24 \%$. The simulation photovoltaic efficiencies remain around $9.25 \%$ but fluctuate from $9.01 \%$ to $9.7 \%$ due to the influence of solar radiation intensity. The average error of photovoltaic efficiency is $4.48 \%$ while the maximum error is $9.30 \%$.

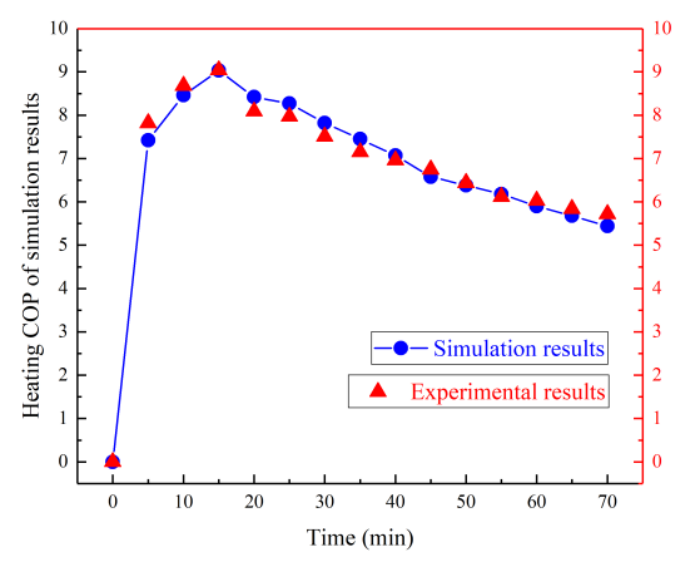

(a)

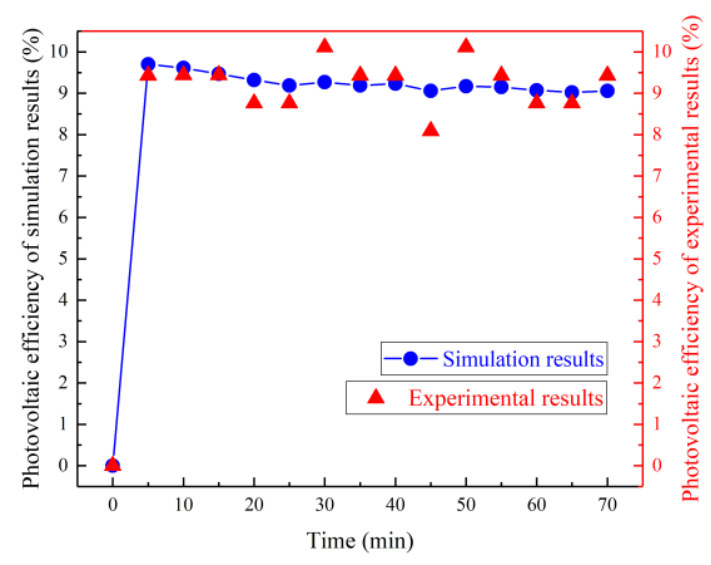

(b)

Fig. 11. (a) Comparison results of experimental and simulated heating COP. (b) Comparison results of experimental and simulated photovoltaic efficiency. 


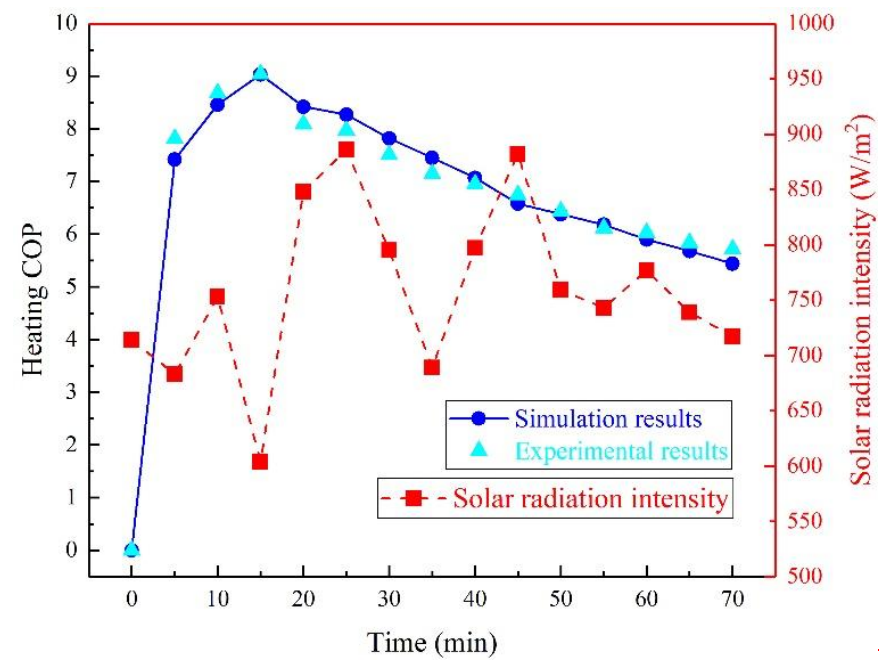

Fig. 11. Comparison results of experimental and simulated heating COP.

Fig. 12 presents the experimental and simulation results of the photovoltaic efficiency. The maximum photovoltaic efficiency is $10.11 \%$ while the minimum is $8.09 \%$, but all the experimental photovoltaic efficiencies fluctuate around $9.24 \%$. The simulation photovoltaic efficiencies remain around $9.25 \%$ but fluctuate from $9.01 \%$ to $9.7 \%$ due to the influence of solar radiation intensity. The average error of photovoltaic efficiency is $4.48 \%$ while the maximum error is $9.30 \%$.

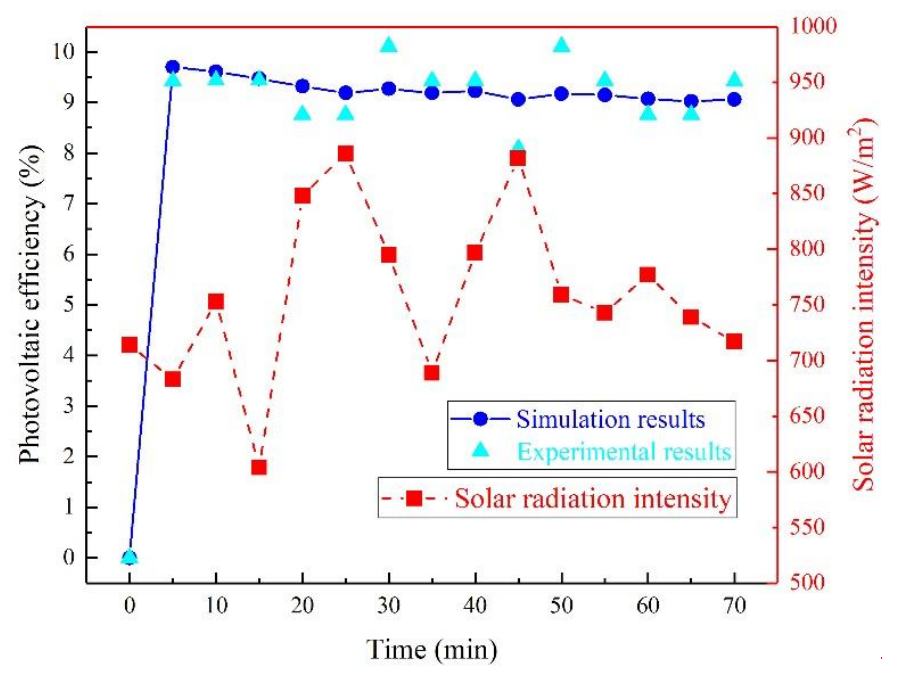

Fig. 12. Comparison results of experimental and simulated photovoltaic efficiency.

\section{Parameter analysis}

In this section, the influences of different parameters (solar radiation intensity, ambient temperature, wind speed, area of PV/T collector) on this system are investigated, and the performance indices of the system under typical working conditions are also given. It should be noted that when one parameter is varied, others keep constant. Pressure ratio of the compressor refers the ratio of pressure of discharged refrigerant vapor and charged refrigerant vapor.

\subsection{Solar radiation intensity}


The influences of solar radiation intensity which varying from $200 \mathrm{~W} / \mathrm{m}^{2}$ to $1000 \mathrm{~W} / \mathrm{m}^{2}$ are shown as follows at the working conditions are: ambient temperature is $25^{\circ} \mathrm{C}$, wind speed is 1.5 $\mathrm{m} / \mathrm{s}$ and area of PV/T collector is $2 \mathrm{~m}^{2}$.

Fig. 12 presents the rising curve of the heating COP and declining curves of thermal, electrical and overall efficiencies. The heating COP is 3.0 for a solar radiation of $200 \mathrm{~W} / \mathrm{m}^{2}$, and it can reach up to 10.8 when the solar radiation is $1000 \mathrm{~W} / \mathrm{m}^{2}$. The refrigerant evaporation temperature and pressure will be increased due to a higher temperature of PV cells. Thus, the compressor consumes less electricity to compress the refrigerant vapor leading to this upward trend. Meanwhile, the heat loss will mount due to a higher temperature difference between PV cells and ambient. Thereby, the thermal and electrical efficiencies of the PV/T panel reduce resulting in a reduction of the overall efficiency.

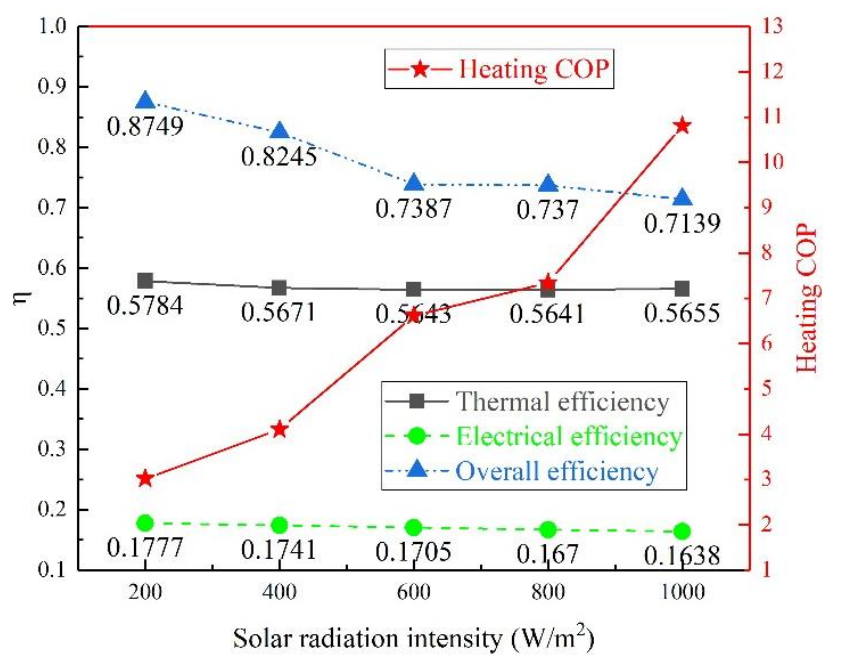

Fig. 12. Influence of solar radiation intensity on heating COP and thermal, electrical, overall efficiencies.

Fig. 13 shows the effect of solar radiation intensity on thermal and electrical output power, pressure ratio and mass flow rate of refrigerant. The thermal and electrical power keep mounting with the increase of the solar radiation intensity. Meanwhile, the pressure ratio of the compressor decreases and the mass flow rate of the refrigerant increases. That is because the increase of the evaporation temperature causes a higher evaporation pressure which equals to the suction pressure of compressor leading to a lower pressure ratio. Furthermore, a larger amount of refrigerant will be needed to transfer extra heat from PV/T collector/evaporator to PCM heat exchanger (condenser) when the PV/T panel absorbs more heat from solar radiation. 


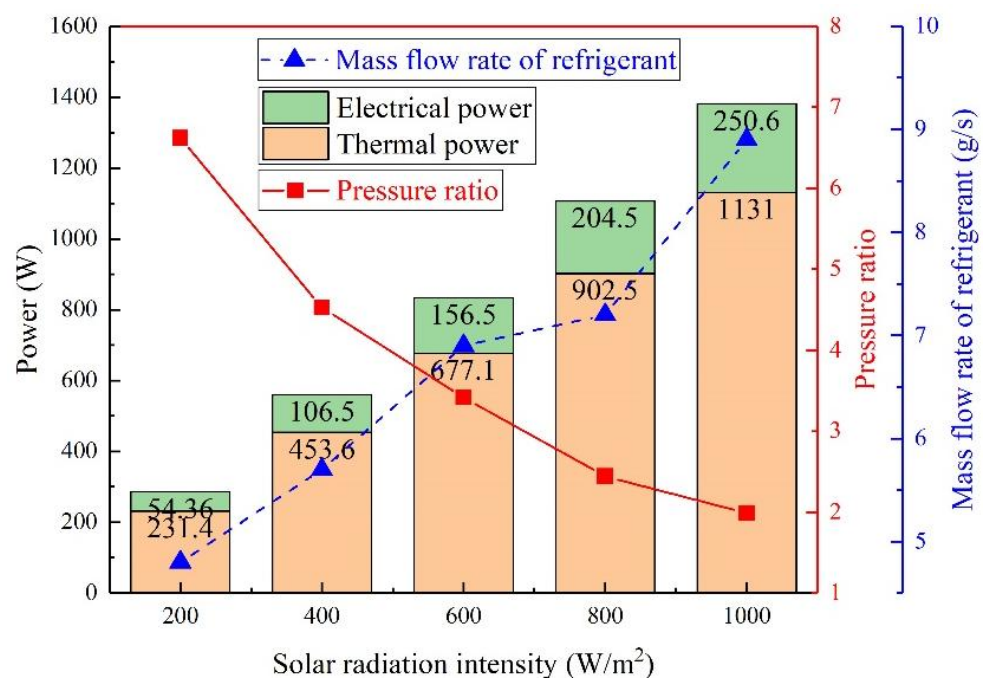

Fig. 13. Influence of solar radiation intensity on electrical and thermal power, pressure ratio and mass flow rate of refrigerant.

As shown in Fig. 14, there is a positive linear correlation between PV cells' electrical power generation and solar radiation intensity while the consumption power of compressor fluctuates around $120 \mathrm{~W}$. When the output power to grid is less than zero, it means the system consumes electricity from the power grid. The electrical power generated by PV panels could meet the demand of the compressor and the system could output electricity to power grid when the solar radiation intensity exceeds $500 \mathrm{~W} / \mathrm{m}^{2}$.

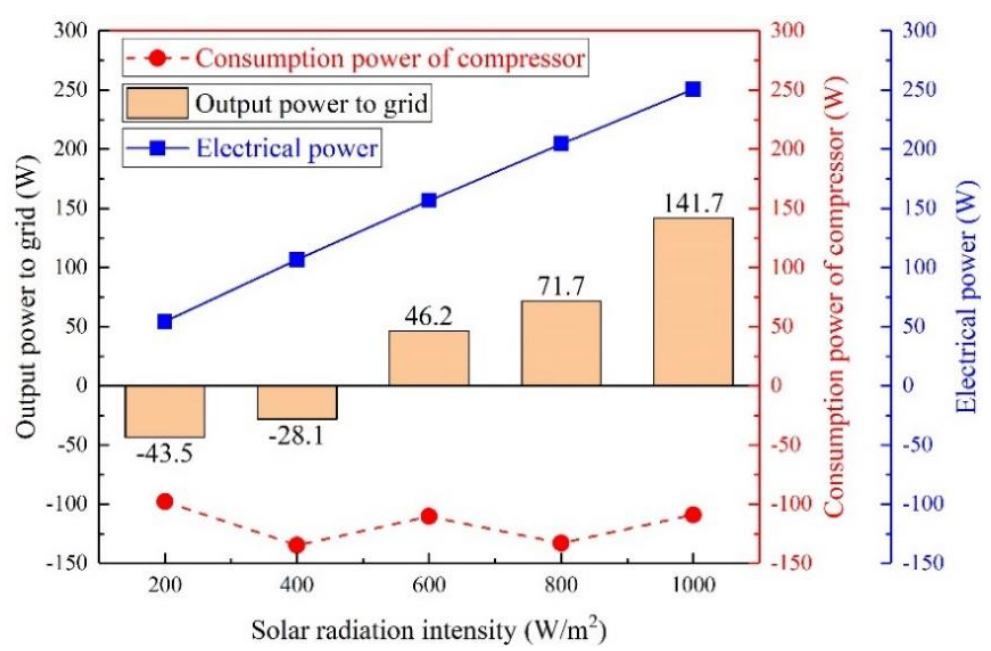

Fig. 14. Influence of solar radiation intensity on electrical power, consumption power of compressor and output power to grid.

\subsection{Ambient temperature}

The influences of ambient temperature which varying from $15{ }^{\circ} \mathrm{C}$ to $35{ }^{\circ} \mathrm{C}$ are shown as follows at the working conditions are: solar radiation intensity is $600 \mathrm{~W} / \mathrm{m}^{2}$, wind speed is $1.5 \mathrm{~m} / \mathrm{s}$ and area of PV/T collector is $2 \mathrm{~m}^{2}$.

Fig. 15 shows that increasing the ambient temperature will increase the heating COP and thermal efficiency but decrease the electrical and overall efficiencies. The temperature difference between PV cells and ambient will reduce when the ambient temperature rises leading to a less 
heat loss from PV/T panel to the surrounding. Thus, the heating COP increases and the electrical efficiency decreases due to a higher temperature of the PV cells while the thermal efficiency increases. However, the electrical efficiency outweighs the thermal efficiency resulting in a reduction of the overall efficiency when the ambient temperature is below $25^{\circ} \mathrm{C}$. The heating COP (9.25) at $35^{\circ} \mathrm{C}$ is higher than $\mathrm{COP}(5.79)$ at $15{ }^{\circ} \mathrm{C}$ by $59.8 \%$, thus a higher ambient temperature is better for the system performance.

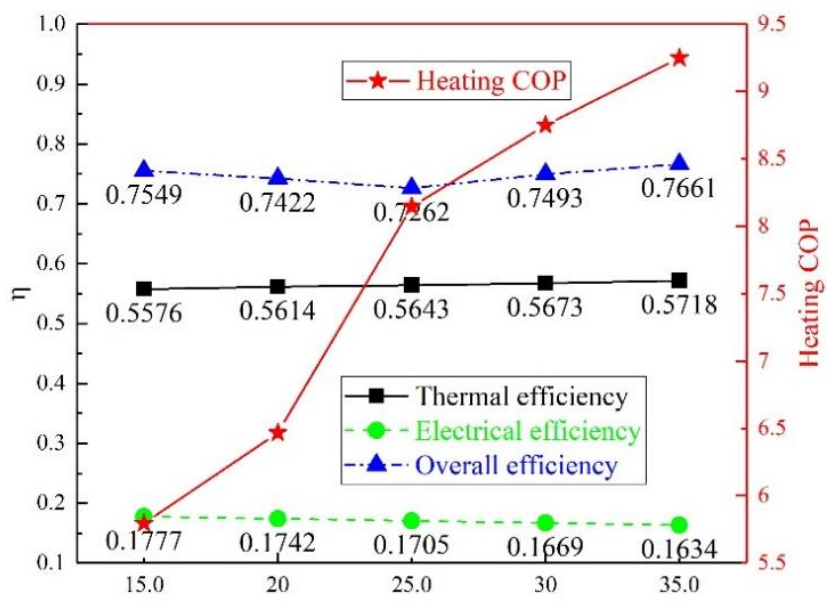

Ambient temperature $\left({ }^{\circ} \mathrm{C}\right)$

Fig. 15. Influence of ambient temperature on heating COP and thermal, electrical, overall efficiencies.

The variation curves of thermal and electrical power, pressure ratio and mass flow rate of refrigerant with the increase of ambient temperature are shown in Fig. 16. The changing curves of the electrical and thermal output power are the same as the electrical and thermal efficiencies. The pressure ratio of the compressor will increase when the ambient temperature is below $25^{\circ} \mathrm{C}$ and decrease when the ambient temperature is over $25^{\circ} \mathrm{C}$. That is because a lower ambient temperature leads to a lower superheat degree of refrigerant which cause a lower pressure ratio, and in the opposite, a higher ambient temperature leads to a higher superheat degree. Moreover, when the ambient temperature exceeds $25{ }^{\circ} \mathrm{C}$, it will influence the thermal efficiency of PV/T collector causing the reduction of pressure ratio. The mass flow rate of the refrigerant will keep climbing when the ambient temperature rises because less heat will lose in the ambient while more heat will be absorbed by refrigerant.

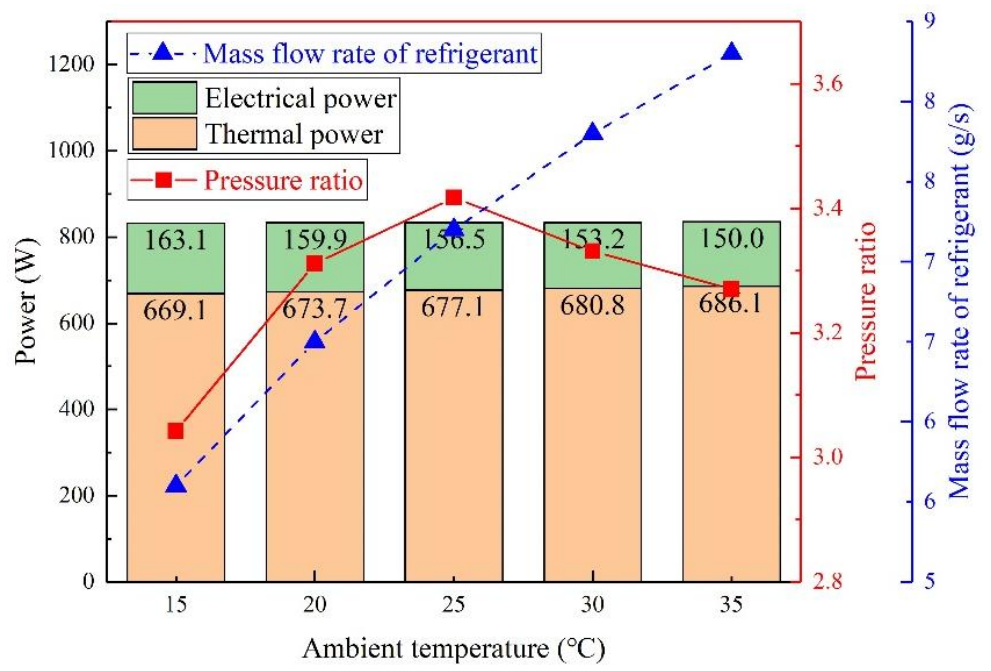


Fig. 16. Influence of ambient temperature on electrical and thermal power, pressure ratio and mass flow rate of refrigerant.

As shown in Fig. 17, the electrical power of PV decreases linearly with the ambient temperature while the consumption power of compressor decreases when the ambient temperature is below $25{ }^{\circ} \mathrm{C}$ and increases when the ambient temperature exceeds $25{ }^{\circ} \mathrm{C}$. The output power to grid reaches its maximum at $25{ }^{\circ} \mathrm{C}$. Because when the ambient temperature is below $25^{\circ} \mathrm{C}$, the effect of environmental heat loss is greater than that of heat-collecting efficiency due to a large temperature difference. However, the effect of a higher ambient temperature on heat-collecting efficiency is greater than that of environmental heat loss when the ambient temperature exceeds $25^{\circ} \mathrm{C}$

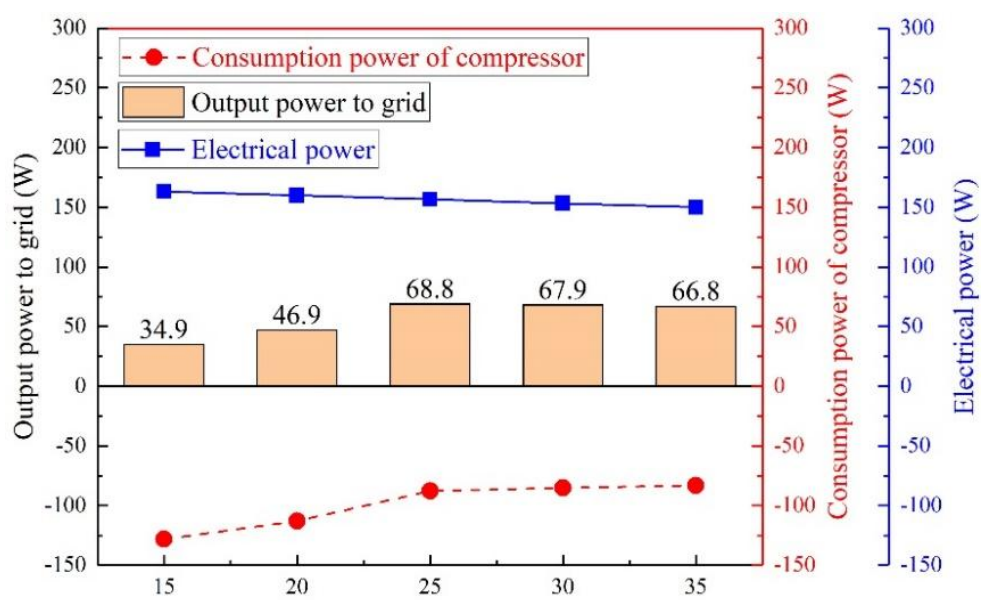

Ambient temperature $\left({ }^{\circ} \mathrm{C}\right)$

Fig. 17. Influence of ambient temperature on electrical power, consumption power of compressor and output power to grid.

\subsection{Wind speed}

The influences of wind speed which varying from $0.5 \mathrm{~m} / \mathrm{s}$ to $2.5 \mathrm{~m} / \mathrm{s}$ are shown as follows at the working conditions are: solar radiation intensity is $600 \mathrm{~W} / \mathrm{m}^{2}$, ambient temperature is $25^{\circ} \mathrm{C}$ and area of $\mathrm{PV} / \mathrm{T}$ collector is $2 \mathrm{~m}^{2}$.

Fig. 18 shows the variation curve of heating COP, thermal, electrical and overall efficiencies with wind speed varying from $0.5 \mathrm{~m} / \mathrm{s}$ to $2.5 \mathrm{~m} / \mathrm{s}$. The heating COP will decrease rapidly when the wind speed is low and steadily when the wind speed increases. More heat will be transferred to the environment and less heat is absorbed by the PV/T panel under a higher wind speed. Meanwhile, evaporation temperature of refrigerant will be decreased and the consumption power of compressor will be increased when the temperature of PV cells rises. Thus, the heating COP drops from 9.4 to 6.8 , which means better wind protection measures should be taken to improve the system performance. 


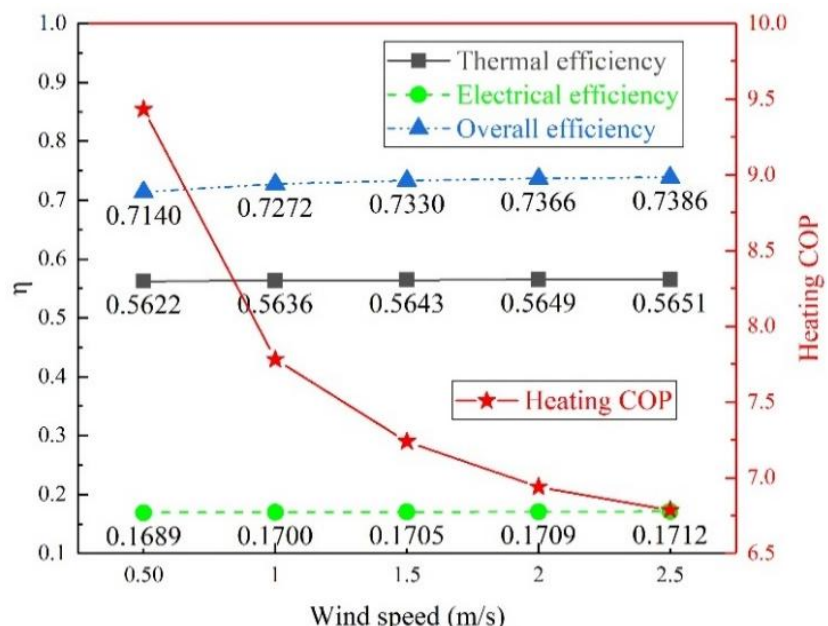

Fig. 18. Influence of wind speed on heating COP and thermal, electrical, overall efficiencies.

The variation curves of thermal and electrical power, pressure ratio and mass flow rate of the refrigerant with the increase of wind speed are shown in Fig. 19. The changing curves of the thermal and electrical power have the same trend as the thermal and electrical efficiencies. Both the pressure ratio and mass flow rate of refrigerant reduce with the increase of the wind speed. That is because more heat will be absorbed by the ambient air while less heat will be transferred by the refrigerant.

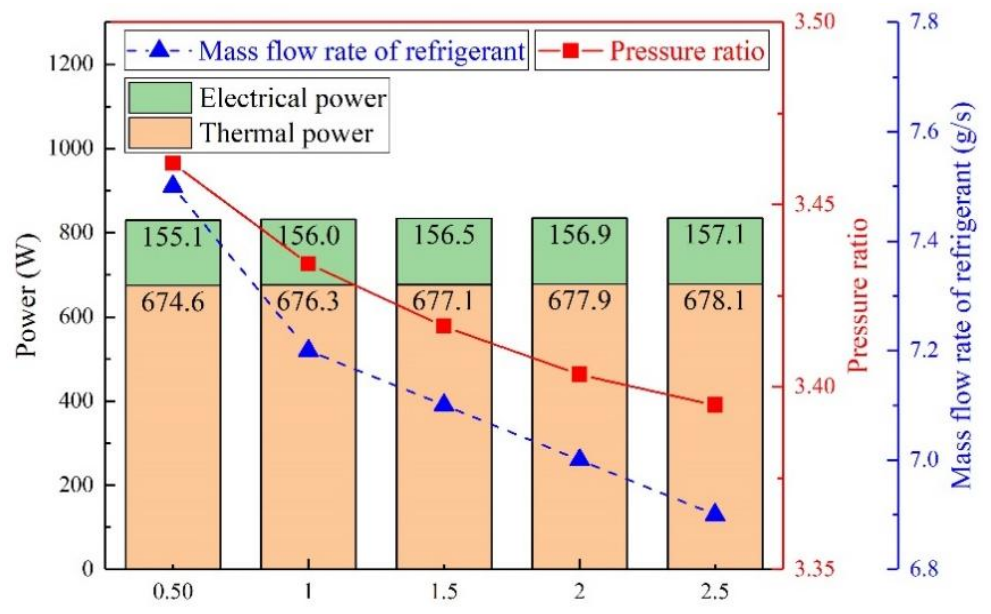

Wind speed $(\mathrm{m} / \mathrm{s})$

Fig. 19. Influence of wind speed on electrical and thermal power, pressure ratio and mass flow rate of refrigerant.

Fig. 20 presents the influence of wind speed on electrical power, consumption power of compressor and output power to grid. The output power to grid decreases rapidly when the wind speed increases from $0.5 \mathrm{~m} / \mathrm{s}$ to $1.5 \mathrm{~m} / \mathrm{s}$ and steadily when the wind speed exceeds $1.5 \mathrm{~m} / \mathrm{s}$. More heat will loss in the environment due to a higher wind speed, and the thermal efficiency will decrease causing a higher consumption power of compressor. 


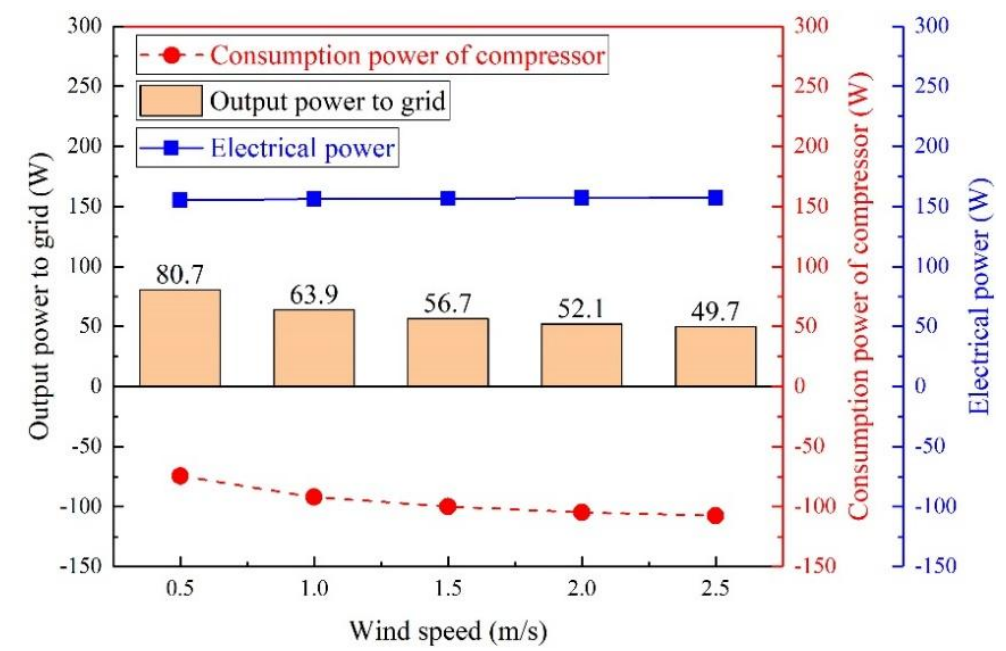

\subsection{Area of PV/T collector}

The influences of the area of PV/T collector which varying from $1 \mathrm{~m}^{2}$ to $3 \mathrm{~m}^{2}$ are shown as follows at the working conditions are: solar radiation intensity is $600 \mathrm{~W} / \mathrm{m}^{2}$, ambient temperature is $25^{\circ} \mathrm{C}$ and wind speed is $1.5 \mathrm{~m} / \mathrm{s}$.

Fig. 21 presents the influence of the area of PV/T collector on pressure ratio, heating COP and overall efficiency. Pressure ratio and overall efficiency reduce with the increase of the area, while the heating COP mounts. That is because a larger area can absorb more heat from the solar radiation, and the extra heat will be transferred by PV/T panel to refrigerant. Meanwhile, the evaporation temperature and pressure will increase leading to a lower pressure ratio and a higher heating COP. The consumption power of the compressor will decrease when the pressure ratio reduces, thus the heating COP increases more rapidly under large area conditions. A higher temperature of the PV cells causes more heat dissipates in the ambient resulting a decrease of the overall efficiency.

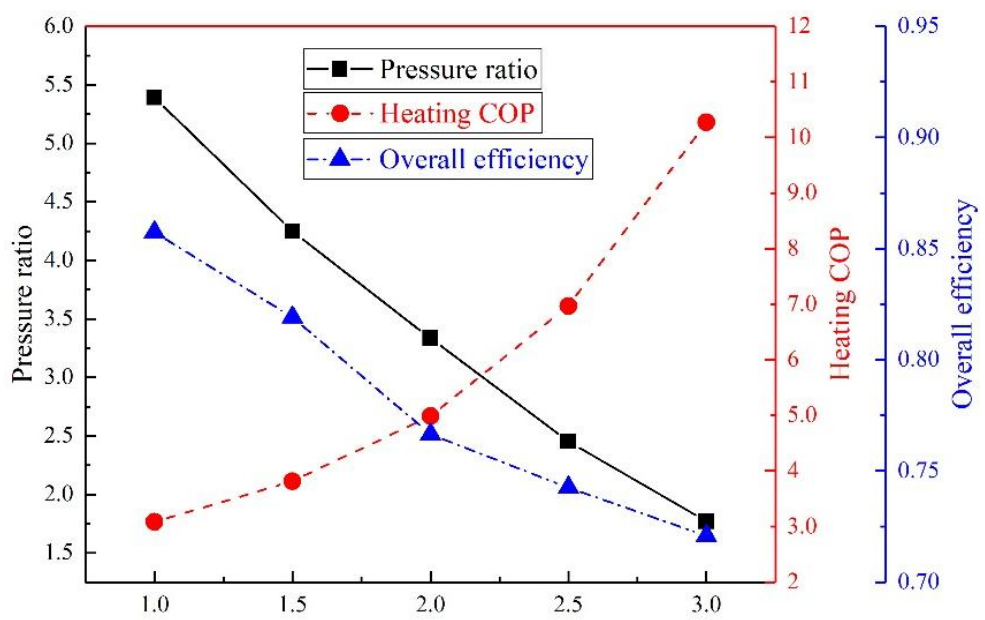

Area of PV/T collector $\left(\mathrm{m}^{2}\right)$

Fig. 21. Influence of the area of PV/T collector on pressure ratio, heating COP and overall efficiency. 
Fig. 22 shows the declining trends of the pressure ratio and increasing trends of the thermal and electrical power influenced by the area of PV/T collector. The thermal and electrical output power are almost linearly and positively correlated with the area of PV/T collector. That is because more heat will gain from the solar radiation and be transferred to the refrigerant when the area increases.

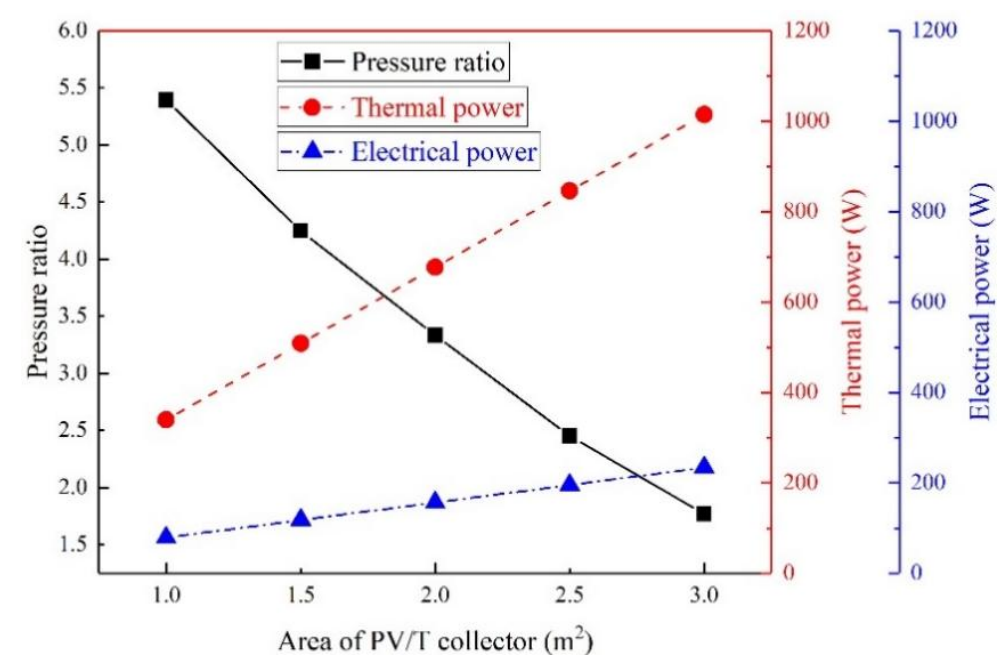

Fig. 22. Influence of the area of PV/T collector on pressure ratio, thermal and electrical power.

As shown in Fig. 23, the mass flow rate of refrigerant will increase when the area increases, while the consumption power of compressor will increase when the area is below $1.5 \mathrm{~m}^{2}$ and decrease when the area is over $1.5 \mathrm{~m}^{2}$. The mass flow rate of refrigerant will increase because the latent heat and heat capacity of refrigerant are the same when more heat is transferred to the refrigerant. The heat absorbed by the PV/T panel and mass flow rate of refrigerant are low, thus the compressor consumes less electricity to compress the refrigerant vapor. With the increase of the area, the mass flow rate mounts resulting in an increase of consumption power. However, the pressure ratio of the compressor will reduce when the area increases over $1.5 \mathrm{~m}^{2}$ leading to a lower consumption power.

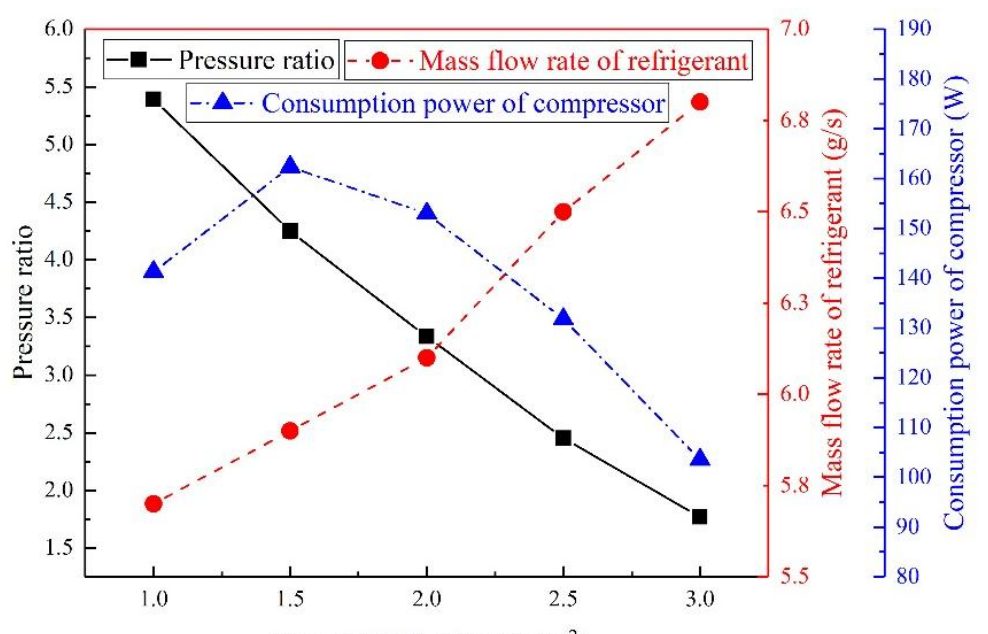

Area of PV/T collector $\left(\mathrm{m}^{2}\right)$

Fig. 23. Influence of the area of $P V / T$ collector on pressure ratio, mass flow rate of refrigerant and consumption power of compressor. 
Fig. 24 illustrates the variation curve of output power to grid with the area of PV/T collector. The electrical power generated by PV panels will meet the demand of compressor when the area of $\mathrm{PV} / \mathrm{T}$ collector is $2 \mathrm{~m}^{2}$. Moreover, the PV cells start to produce electricity to power grid when the area is over $2 \mathrm{~m}^{2}$ which means a larger PV/T panel is better for the system performance under the same system conditions.

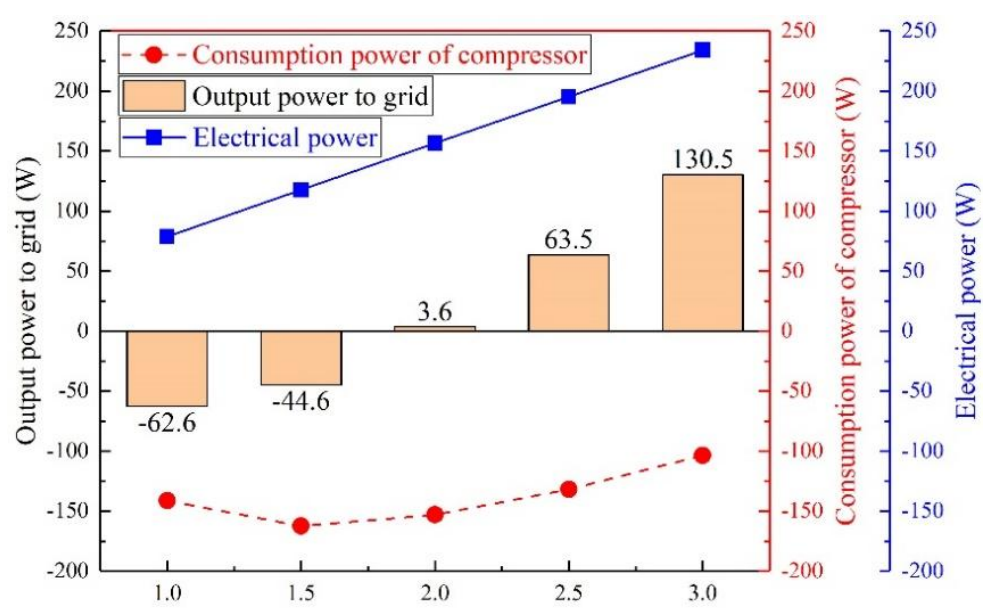

Area of $\mathrm{PV} / \mathrm{T}$ collector $\left(\mathrm{m}^{2}\right)$

Fig. 24. Influence of area of PV/T collector on electrical power, consumption power of compressor and output power to grid.

\subsection{Feasibility analysis of the system}

Nowadays, the Chinese government promotes the policy of using electricity for residential heating instead of burning coal for heating in northern China to reduce carbon dioxide emissions. The solar PV/T heat pump coupled with build-in PCM heat storage system is suitable for residential heating due to its advantages: (1) high efficiency; (2) low energy consumption; (3) stable residential heating supply; (4) zero carbon emissions. Table. 4 presents the typical operating conditions and parameters of the system. It is a typical spring/autumn day in northern China.

Table. 4. Typical operating conditions and parameters of the system.

\begin{tabular}{llll}
\hline Parameters & Nomenclature & Value & Unit \\
\hline Solar radiation intensity & $I$ & 600 & $\mathrm{~W} / \mathrm{m}^{2}$ \\
Sunshine duration & $t_{s}$ & 8 & hour \\
Ambient temperature & $T_{a}$ & 15 & ${ }^{\circ} \mathrm{C}$ \\
Wind speed & $v_{\text {wind }}$ & 1.5 & $\mathrm{~m} / \mathrm{s}$ \\
Area of the collector & $A$ & 20 & $\mathrm{~m}^{2}$ \\
Packing factor & $\beta_{p}$ & 1 & {$[-]$} \\
Heating area & $A_{h a}$ & 100 & $\mathrm{~m}^{2}$ \\
Heat loss per square meter & $P_{L}$ & 50 & $\mathrm{~W} / \mathrm{m}^{2}$ \\
Filling volume of the PCM & $V_{P C M}$ & 0.57 & $\mathrm{~m}^{3}$ \\
External diameter of the inside pipe & $D_{l}$ & 0.012 & $\mathrm{~m}$ \\
Internal diameter of the inside pipe & $d_{l}$ & 0.010 & $\mathrm{~m}$ \\
External diameter of the outside pipe & $D_{2}$ & 0.074 & $\mathrm{~m}$ \\
Internal diameter of the outside pipe & $d_{2}$ & 0.072 & $\mathrm{~m}$
\end{tabular}


Table. 5 presents the simulation performance indices of the system under typical day conditions. The PV/T collector can transfer 213.9 MJ heat from the ambient to the PCM heat exchanger, and the heat will be stored in phase change materials and concrete. The build-in PCM heat storage can release the heat for 10 hours at $5.94 \mathrm{~kW}$ during the night while the heat loss power of $100 \mathrm{~m}^{2}$ area is $5 \mathrm{~kW}$. During autumn, winter and early spring in northern China, the heating system is necessary to keep indoor temperature above $20^{\circ} \mathrm{C}$. Thus, the system can achieve the heating needs of the users and keep the indoor temperature steady. Meanwhile, the system can output $21.4 \%(2.79 \mathrm{kWh})$ of the power generated by PV panels to the grid while $78.6 \%$ of it consumed by the compressor. The heating COP of the system is 5.79 , and the overall efficiency is $75.49 \%$.

Table. 5. Simulation performance indices of the system under typical day conditions.

\begin{tabular}{lll}
\hline Parameters & Value & Unit \\
\hline Total heat storage & 213.9 & $\mathrm{MJ}$ \\
Photovoltaic power & 1.63 & $\mathrm{~kW}$ \\
Photovoltaic efficiency & 17.77 & $\%$ \\
PV/T thermal efficiency & 55.76 & $\%$ \\
Heating COP & 5.79 & {$[-]$} \\
Overall efficiency & 75.49 & $\%$ \\
Cumulative power generation & 13.05 & $\mathrm{kWh}$ \\
Consumption power of compressor & 10.26 & $\mathrm{kWh}$ \\
Output power to grid & 2.79 & $\mathrm{kWh}$ \\
Temperature range of underfloor heating & $22-31$ & ${ }^{\circ} \mathrm{C}$ \\
Heating power at night & 5.94 & $\mathrm{~kW}$ \\
Heat loss power & 5.00 & $\mathrm{~kW}$ \\
Heating hour & 10.00 & $\mathrm{hour}$ \\
\hline
\end{tabular}

Table. 6 illustrates the comparison of cost between the proposed system and conventional air conditioning system. The operating cost of the proposed system is under zero because users could sell spare electricity to power grid and get profit. Fig. 25 shows the cost variation curves of these two systems. The initial cost of the proposed system is much higher than conventional air conditioning system due to the underfloor heating equipment and PV/T panels, etc. However, the air conditioning system consumes a lot of electricity during the night for heating supply. Thus, the cost of these two systems will be the same after about 4 years, and the cost of proposed system keeps reduce while the cost of air conditioning system still climbs. Moreover, underfloor heating system which using radiative heating is more comfort and silence for users than air conditioner.

Table. 6. Cost comparison between the proposed system and conventional air conditioning

\begin{tabular}{lccc}
\multicolumn{4}{c}{ system. } \\
\hline Heating system & $\begin{array}{c}\text { Initial } \\
\text { cost }(¥)\end{array}$ & $\begin{array}{c}\text { Operating } \\
\text { cost (¥/year) }\end{array}$ & $\begin{array}{c}\text { Maintenance } \\
\text { cost (¥/year) }\end{array}$ \\
\hline Proposed system & 22000 & -764 & 550 \\
Air conditioning system & 4500 & 4024 & 225 \\
\hline
\end{tabular}




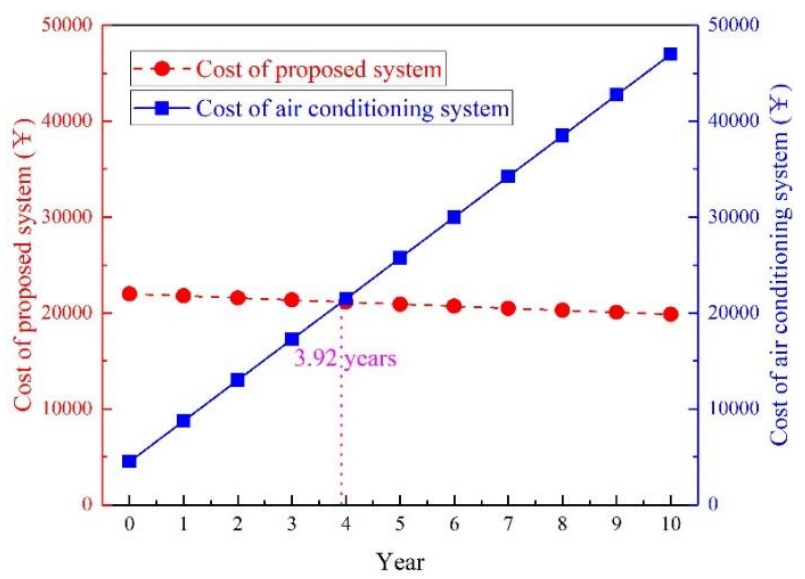

Fig. 25. Cost variation curves of proposed system and air conditioning system.

\section{Moreover, Fig. 26 illustrates the comparison of thermal and electrical efficiencies of different} PV/T systems. The electrical and thermal efficiencies of solar PV/T heat pump which proposed in this paper are higher than that of most air, water or PCM based PV/T systems. Thus, the solar PV/T heat pump coupled with build in PCM heat storage system has a higher comprehensive energy utilization efficiency than most PV/T systems. Meanwhile, the adoption of PCM heat storage can also enhance the stability of solar PV/T heat pump system.
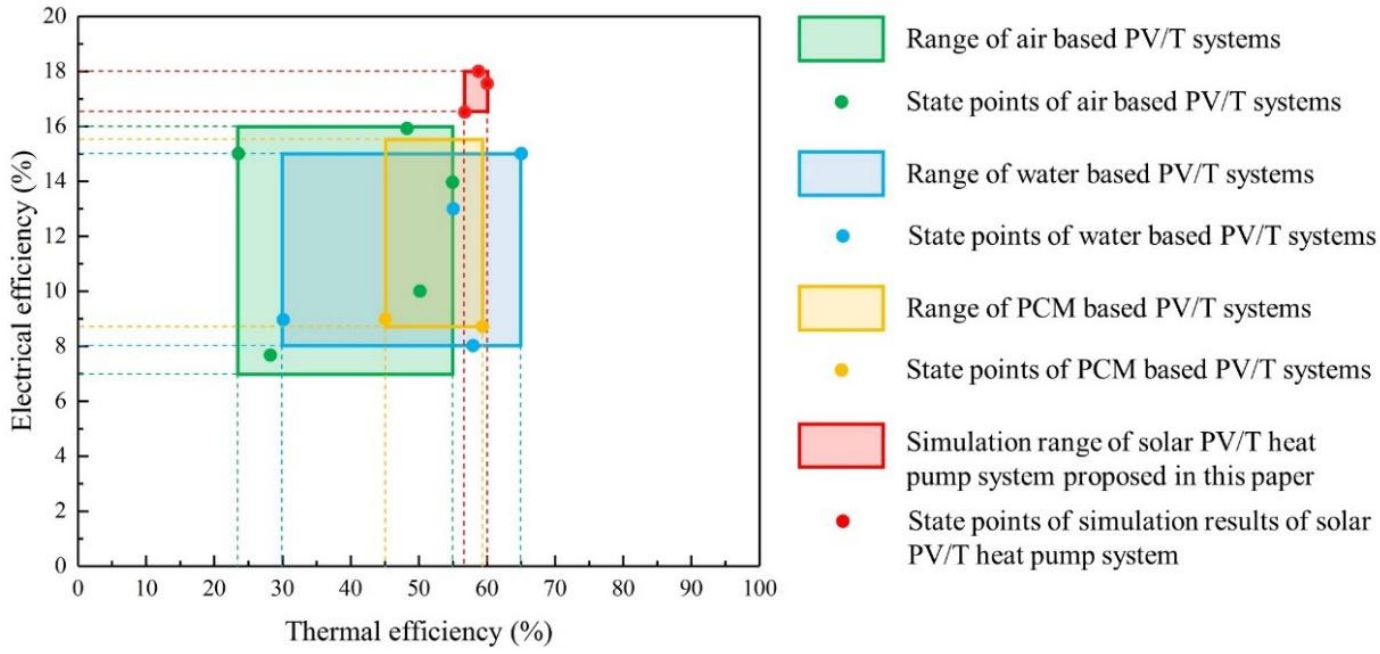

Fig. 26. Comparison of thermal and electrical efficiencies of different PV/T systems (Ahn et al., 2015; Al Waeliet al., 2017; Hu et al., 2016; Li et al., 2015; Mojumder et al., 2016; Qiu et al., 2015)

\section{Conclusion}

A building-coupled cogeneration system using solar PV/T heat pump and build-in PCM heat storage is proposed in this paper. The mathematical model of the system is established and verified to analyze the system performance under different conditions. The main conclusions can be drawn as follows:

(1) The temperature of underfloor heating which using build-in PCM heat storage can reach $22{ }^{\circ} \mathrm{C}$ to $31{ }^{\circ} \mathrm{C}$ after 39 hours when the circulating water is $40^{\circ} \mathrm{C}$ which is stable and suitable for residential heating.

(2) The heating COP increases with the increase of solar radiation, ambient temperature, area 

ambient temperature.

(32) The heating COP can reach 6.6 which is $94 \%$ higher than conventional air conditioning system when solar radiation intensity is $600 \mathrm{~W} / \mathrm{m}^{2}$, ambient temperature is $25^{\circ} \mathrm{C}$, wind speed is 1.5 $\mathrm{m} / \mathrm{s}$ and area of PV/T collector is $2 \mathrm{~m}^{2}$ while the electrical, thermal and overall efficiencies are $17.05 \%, 56.43 \%$ and $73.87 \%$, respectively.

(4르 A $2 \mathrm{~m}^{2} \mathrm{PV} / \mathrm{T}$ panel can meet the power demand of the system and heating demand of a $10 \mathrm{~m}^{2}$ room when the solar radiation intensity is $500 \mathrm{~W} / \mathrm{m}^{2}$. Moreover, the PV/T panel can output electricity to power grid if the panel area is bigger than $2 \mathrm{~m}^{2}$ or solar radiation intensity is higher than $500 \mathrm{~W} / \mathrm{m}^{2}$.

The mathematical model established in this paper can also be used to analyze and optimize the solar PV/T heat pump system. However, the mathematical model of this system is for stable working conditions instead of transient. The establishment of dynamic model is needed for further predict and analyze accurately of solar assisted heat pump system under dynamic working conditions.

\section{Acknowledgements}

This research work is funded by the International Research Cooperation Program of Shanghai (Grant No. 18160710500).

\section{Nomenclature:}

\section{Symbols}

$\begin{array}{ll}A & \text { area }\left(\mathrm{m}^{2}\right) \\ W & \text { width of the } \mathrm{PV} / \mathrm{T} \text { collector/evaporator }(\mathrm{m}) \\ L & \text { length of the } \mathrm{PV} / \mathrm{T} \text { collector/evaporator }(\mathrm{m}) \\ \Delta H & \text { latent heat }(\mathrm{kJ} / \mathrm{kg}) \\ h & \text { heat transfer coefficient }\left(\mathrm{W} / \mathrm{m}^{2} \cdot \mathrm{K}\right) \\ U & \\ & \text { heat loss coefficient }\left(\mathrm{W} / \mathrm{m}^{2} \cdot \mathrm{K}\right) \\ C_{p} & \text { specific heat at constant pressure }(\mathrm{kJ} / \mathrm{kg} \cdot \mathrm{K}) \\ d & \text { inner diameter }(\mathrm{m}) \\ D & \text { external diameter }(\mathrm{m}) \\ t / T & \text { temperature }(\mathrm{K}) \\ I & \text { solar radiation intensity }\left(\mathrm{W} / \mathrm{m}^{2}\right) \\ Q & \text { heat transfer rate }(\mathrm{W}) \\ F & \text { collector efficiency }(-) \\ R & \text { thermal resistance }\left(\mathrm{m}^{2} \cdot \mathrm{K} / \mathrm{W}\right) \\ R e & \text { Reynolds number }(-) \\ R a & \text { Rayleigh number }(-) \\ P r & \text { Prandtl number }(-)\end{array}$


647

648 Greek symbols

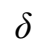

$\tau$

$a$

$\beta$

$\varepsilon$

$\kappa$

$\sigma$

$\rho$

$\lambda$

$\eta$

$\chi$

649

650 Subscripts

$p, p v$

$g, c_{1}$

$c / c_{2}$

conc

EVA

PCM

mel

ref

b

$c v$

$r d$

$r b$

a

$l$

$L$

rc

$e$

$e i$

$u$

th/R

tp

ove

$a b s$ wind speed $(\mathrm{m} / \mathrm{s})$

mass flowrate $(\mathrm{kg} / \mathrm{s})$

gravitational acceleration $\left(\mathrm{m} / \mathrm{s}^{2}\right)$

pressure $(\mathrm{kPa})$

power (W)

volume flow rate $\left(\mathrm{m}^{3} / \mathrm{h}\right)$

thickness (m)

transmittance (-)

absorption ratios (-)

packing factor (-)

emissivity (-)

thermal conductivity $(\mathrm{W} / \mathrm{m} \cdot \mathrm{K})$

Stefan-Boltzmann constant (-)

density $\left(\mathrm{kg} / \mathrm{m}^{3}\right)$

compressor volumetric efficiency (-)

efficiency (-)

polytropic index (-)

PV cells

external glass cover

PV-glazing cover

concrete

EVA grease

phase change material

melting point

refrigerant

baseboard

convection

radiation

roll-bond panel pipe

ambient

liquid

lost

reference

electrical

electrical insulation

uesful

thermal

two-phase flow

oveall

absorb 


$\begin{array}{ll}h p & \text { heat pipe } \\ s h & \text { superheated } \\ v & \text { vapor } \\ \text { cond } & \text { condensation } \\ \text { eva } & \text { evaporation } \\ \text { ot } & \text { outer pipe } \\ e q & \text { equivalent } \\ h x & \text { heat exchanger } \\ \text { dis } & \text { discharge } \\ \text { suc } & \text { suction } \\ \text { in } & \text { inlet } \\ \text { out } & \text { outlet } \\ c w & \text { circulating water }\end{array}$

\section{References:}

653

2019. Review and outlook of world energy development, Non-Fossil Energy Development in China. pp. 1-36.

Ahn, J.-G., Kim, J.-H., Kim, J.-T., 2015. A Study on Experimental Performance of Air-Type PV/T Collector with HRV. Energy Procedia 78, 3007-3012.

Al-Waeli, A.H.A., Sopian, K., Kazem, H.A., Chaichan, M.T., 2017. Photovoltaic/Thermal (PV/T) systems: Status and future prospects. Renewable and Sustainable Energy Reviews 77, 109-130.

Cabeza, L.F., Castell, A., Barreneche, C., de Gracia, A., Fernández, A.I., 2011. Materials used as PCM in thermal energy storage in buildings: A review. Renewable and Sustainable Energy Reviews 15(3), 1675-1695.

Caetano, N.S., Mata, T.M., Martins, A.A., Felgueiras, M.C., 2017. New Trends in Energy Production and Utilization. Energy Procedia 107, 7-14.

Del Amo, A., Martínez-Gracia, A., Bayod-Rújula, A.A., Cañada, M., 2019. Performance analysis and experimental validation of a solar-assisted heat pump fed by photovoltaic-thermal collectors. Energy 169, 1214-1223.

Diallo, T.M.O., Yu, M., Zhou, J., Zhao, X., Shittu, S., Li, G., Ji, J., Hardy, D., 2019. Energy performance analysis of a novel solar PVT loop heat pipe employing a microchannel heat pipe evaporator and a PCM triple heat exchanger. Energy 167, 866-888.

Fayaz, H., Rahim, N.A., Hasanuzzaman, M., Rivai, A., Nasrin, R., 2019. Numerical and outdoor real time experimental investigation of performance of PCM based PVT system. Solar Energy 179, 135-150.

Fiorentini, M., Cooper, P., Ma, Z., Robinson, D.A., 2015. Hybrid Model Predictive Control of a Residential HVAC System with PVT Energy Generation and PCM Thermal Storage. Energy Procedia 83, 21-30.

Hosseinzadeh, M., Sardarabadi, M., Passandideh-Fard, M., 2018. Energy and exergy analysis of nanofluid based photovoltaic thermal system integrated with phase change material. Energy 147, 636-647.

Hu, J., Chen, W., Yang, D., Zhao, B., Song, H., Ge, B., 2016. Energy performance of ETFE cushion roof integrated photovoltaic/thermal system on hot and cold days. Applied Energy 173, 40-51. 
Huang, B.J., Lee, C.P., 2004. Long-term performance of solar-assisted heat pump water heater. Renewable Energy 29(4), 633-639.

Huide, F., Xuxin, Z., Lei, M., Tao, Z., Qixing, W., Hongyuan, S., 2017. A comparative study on three types of solar utilization technologies for buildings: Photovoltaic, solar thermal and hybrid photovoltaic/thermal systems. Energy Conversion and Management 140, 1-13.

Jankowski, N.R., McCluskey, F.P., 2014. A review of phase change materials for vehicle component thermal buffering. Applied Energy 113, 1525-1561.

Kazemian, A., Salari, A., Hakkaki-Fard, A., Ma, T., 2019. Numerical investigation and parametric analysis of a photovoltaic thermal system integrated with phase change material. Applied Energy 238, 734-746.

Keček, D., Mikulić, D., Lovrinčević, Ž., 2019. Deployment of renewable energy: Economic effects on the Croatian economy. Energy Policy 126, 402-410.

Kuik, O., Branger, F., Quirion, P., 2019. Competitive advantage in the renewable energy industry: Evidence from a gravity model. Renewable Energy 131, 472-481.

Kuznik, F., Virgone, J., Roux, J.-J., 2008. Energetic efficiency of room wall containing PCM wallboard: A full-scale experimental investigation. Energy and Buildings 40(2), 148-156.

Li, G., Pei, G., Ji, J., Yang, M., Su, Y., Xu, N., 2015. Numerical and experimental study on a PV/T system with static miniature solar concentrator. Solar Energy 120, 565-574.

Ma, Y., 2013. Analysis of Electrical Efficiency for Positive Displacement Refrigerant Compressor. Journal of Refrigeration.

Mojumder, J.C., Chong, W.T., Ong, H.C., Leong, K.Y., Abdullah Al, M., 2016. An experimental investigation on performance analysis of air type photovoltaic thermal collector system integrated with cooling fins design. Energy and Buildings 130, 272-285.

Nahar, A., Hasanuzzaman, M., Rahim, N.A., 2017. A Three-Dimensional Comprehensive Numerical Investigation of Different Operating Parameters on the Performance of a Photovoltaic Thermal System With Pancake Collector. Journal of Solar Energy Engineering 139(3), 031009.

Othman, M.Y., Hamid, S.A., Tabook, M.A.S., Sopian, K., Roslan, M.H., Ibarahim, Z., 2016. Performance analysis of PV/T Combi with water and air heating system: An experimental study. Renewable Energy 86, 716-722.

P. Hartnett, J., M. Rohsenow, W., 1973. Handbook of Heat Transfer.

Paolo Frankl, S., 2010. Technology Roadmap: Solar Photovoltaic Energy.

Pereira da Cunha, J., Eames, P., 2016. Thermal energy storage for low and medium temperature applications using phase change materials - A review. Applied Energy 177, 227-238.

Pietrosemoli, L., Rodríguez-Monroy, C., 2019. The Venezuelan energy crisis: Renewable energies in the transition towards sustainability. Renewable and Sustainable Energy Reviews 105, 415-426. Qiu, Z., Zhao, X., Li, P., Zhang, X., Ali, S., Tan, J., 2015. Theoretical investigation of the energy performance of a novel MPCM (Microencapsulated Phase Change Material) slurry based PV/T module. Energy 87, 686-698.

R. Turns, S., 2006. Thermodynamics. Concepts and applications.

Stojanović, B., Akander, J., 2010. Build-up and long-term performance test of a full-scale solar-assisted heat pump system for residential heating in Nordic climatic conditions. Applied Thermal Engineering 30(2-3), 188-195.

Tsai, H.-L., 2015. Modeling and validation of refrigerant-based PVT-assisted heat pump water heating (PVTA-HPWH) system. Solar Energy 122, 36-47. 
725 Wolf, M., 1976. Performance analyses of combined heating and photovoltaic power systems for 726 residences. Energy Conversion 16(1), 79-90.

727 Zhou, C., Liang, R., Zhang, J., Riaz, A., 2019. Experimental study on the cogeneration performance 728 of roll-bond-PVT heat pump system with single stage compression during summer. Applied 729 Thermal Engineering 149, 249-261.

730

731

732 


\title{
Performance analysis of solar assisted heat pump coupled with build-in PCM heat storage based on PV/T panel
}

$\mathrm{PV} / \mathrm{T}$ (photovoltaic/thermal) technology is a combination of PV module (photovoltaic utilization) and collector (photothermal utilization), which can improve the comprehensive utilization efficiency of solar energy and has a broad application prospect. In this paper, PV/T module is coupled with heat pump evaporator to form a direct-expansion solar PV/T heat pump which is suitable for heat application in high latitude area. To achieve stable residential heating, a solar PV/T heat pump system coupled with build-in PCM (phase change material) heat storage is therefore proposed and simulated. Meanwhile, the mathematical model of solar PV/T heat pump coupled with build-in PCM heat storage system is established and verified. The simulation results show that the temperature of underfloor heating which using build-in PCM heat storage can reach $22{ }^{\circ} \mathrm{C}$ to $31^{\circ} \mathrm{C}$ after 39 hours when the circulating water is $40{ }^{\circ} \mathrm{C}$. Moreover, the heating COP (Coefficient of Performance) increases with the increase of solar radiation, ambient temperature and area of PV/T collector, and decrease of wind speed, respectively. A $20 \mathrm{~m}^{2} \mathrm{PV} / \mathrm{T}$ panel module can output $21.4 \%$ of the electricity to power grid when the solar radiation intensity is $600 \mathrm{~W} / \mathrm{m}^{2}$ and meet the heat demand of a $100 \mathrm{~m}^{2}$ room while maintain the operation of the system. Meanwhile, the heating COP can reach 5.79 which is $70 \%$ higher than the conventional air conditioning system and the electrical, thermal, overall efficiencies are $17.77 \%, 55.76 \%$ and $75.49 \%$, respectively.

\section{Introduction}

The total amount of energy consumption in the world is constantly climbing (2019; Caetano et al., 2017). The consumption of fossil energy has brought about energy crisis and environmental crisis (Pietrosemoli and Rodríguez-Monroy, 2019). Without action, $\mathrm{CO}_{2}$ emissions from burning fossil fuels will be doubled by 2050 (Paolo Frankl, 2010). Therefore, the development and utilization of renewable energy has become one of the effective solutions (Keček et al., 2019). Solar energy has become the first choice due to its characteristics of ubiquity, abundance and sustainability (Kuik et al., 2019; Tsai, 2015), which is mainly used in two ways: photothermal and photovoltaic. 11\% of global electricity will be provided by PV by 2050 (Paolo Frankl, 2010). However, the electrical efficiency of PV cells decreases with the increase of the temperature of PV cells (Huide et al., 2017). A cooling system can be added to reduce the temperature of PV cells while the remaining heat of PV panel are absorbed by working fluid which can be employed as a useful thermal energy for heat applications in buildings. 
The PV/T technology coupled PV modules with thermal collectors was first proposed by Wolf et al (Wolf, 1976) to reduce PV cells temperature and improve electrical efficiency. The $\mathrm{PV} / \mathrm{T}$ system can recover waste heat from the PV panel to improve comprehensive energy utilization efficiency. PV/T design optimizations are carried out to improve the system efficiency in recent years. Nahar et al. (Nahar et al., 2017) designed a novel pancake-shaped flow channel for PV/T system, and integrated the flow channel with the PV baseboard. They found that the temperature of the PV panel is reduced by $42{ }^{\circ} \mathrm{C}$, and the electrical efficiency is increased by $2 \%$. Othman et al. (Othman et al., 2016) proposed a parallel, double pass flat plate collector which was adopted in a two fluids PV/T system. Their results showed that the electrical efficiency and thermal efficiency are $17 \%$ and $76 \%$, respectively.

The combination of PCM and PV/T panel is an effective way to stabilize the operating temperature of PV cells and improves the overall efficiency. Hosseinzadeh et al. (Hosseinzadeh et al., 2018) investigated the effect of simultaneous use of nanofluid as coolant as well as an organic paraffin as the phase change material on the electrical and thermal efficiencies. They demonstrated that the use of PCM in nanofluid based PVT/PCM system enhances the thermal output power of conventional PV/T system by $29.6 \%$. Kazemian et al. (Kazemian et al., 2019) developed and simulated a comprehensive three-dimensional model of PV/T system integrated with PCM. Their simulation results presented that the PV/T-PCM system have lower surface temperature compared to PV/T system, and as the thermal conductivity of PCM enhances, both electrical and thermal efficiencies increase. Fayaz et al. (Fayaz et al., 2019) investigated the PCM based PV/T system, and the experimental validation was carried out to verify the numerical model. They found that the electrical efficiency is achieved as $13.98 \%$ and $13.87 \%$ numerically and experimentally respectively, and the electrical performance is improved as $6.2 \%$ and $4.8 \%$ for PV/T-PCM system based on the numerical and experimental results respectively.

Different working fluids like water, air, nanofluid and refrigerant are also used to cool the PV module. Huang and Lee (Huang and Lee, 2004) conducted long-term tests on the direct-expansion solar heat pump which adopted refrigerant as working fluid to verify the stability of the work. The total running time of their prototype is over 20000 hours, and the measured energy consumption is $0.019 \mathrm{kWh} / \mathrm{l}$ of hot water at $57{ }^{\circ} \mathrm{C}$ which is much less than traditional solar water heater. Stojanović and Akander (Stojanović and Akander, 2010) used direct-expansion heat pump for independent buildings heating and domestic hot water supply. In their system, the collector area is $42.5 \mathrm{~m}^{2}$ and heat pump power is $8.4 \mathrm{~kW}$, they measured that the actual indoor temperature is no less than $20^{\circ} \mathrm{C}$ during the testing period. Alejandro Del Amo et al. (Del Amo et al., 2019) verified the feasibility of solar PV/T heat pump through experiments. They obtained that the highest COP of the system can reach 4.62. Meanwhile, the PV module provides $67.6 \%$ of the power demand, and the payback period is 6 years.

In addition to optimize the PV/T panel, the adoption of PCM as heat storage is also a good way to stabilize the system. Kuznik et al. (Kuznik et al., 2008) adopted PCM wallboard heat storage and conducted comparative experiments. In their study, the system can effectively reduce heat loss, keep the room warm and improve indoor thermal comfort. Fiorentini et al. (Fiorentini et al., 2015) combined PCM storage with PV/T system, and the roof was used as PV/T layout location. The PCM storage adopted in their system can keep indoor comfort within a certain and potentially variable thermal comfort range. Diallo et al. (Diallo et al., 2019) proposed the PVT-LHP (PVT Loop Heat Pipe) technology employing PCM triple heat exchanger, the total 
energy efficiency of the presented system is improved by $28 \%$, and the heating COP is 2.2 times than that of a traditional PV/T system.

Owing to the instability of solar energy, traditional solar PV/T system cannot continuously and stably supply heat or power generation when solar irradiation is weak such as rainy day or winter. Consequently, the market of PV/T technology compared with PV or PT system is still very low. PV/T can adapt to the characteristics of low intensity, instability and intermittency of solar energy better if it can be combined with accumulator and heat storage. However, additional space is required to install heat storage tank, which is not suitable for use in urban areas where land resources are scarce. Therefore, in this paper, a coupling design of solar PV/T heat pump and build-in PCM heat storage is proposed and the parallel air source heat exchanger is also adopted to enhance the stability of the system. The build-in PCM heat storage used for underfloor heating is a combination of PCM and building materials, which can save more space compared to conventional PCM storage tank system. Firstly, the composition and operation modes of the system are introduced. According to the system principle, the mathematical model is established and verified, and the build-in PCM heat storage sub-system which using for residential heating is also proposed and simulated. Then the influences of different parameters on system performance are analyzed. Finally, the feasibility analysis of the system is conducted. The objective of this paper is to provide a promising method to realize stable, high efficiency, environmental friendly residential heating in high latitude area with no energy consumption from power grid.

\section{System description}

Fig. 1 shows the schematic diagram of the system based on solar PV/T heat pump, which is consisted of four main parts: solar PV/T heat pump module, parallel air source heat pump module, heat storage module and electrical module. The blue lines represent low temperature working fluid, and in the opposite, red lines represent high temperature. The yellow lines represent the electricity flow direction. The arrows show the working fluid direction. The system can be divided into two operating modes, which are listed as follows.

(1) Sunny day operating mode: The electricity generated by PV panel is used to drive the pumps and compressor, and the excess electricity will be recovered to the power grid or drive the air conditioning. However, the PV panel heated by solar radiation will be resulted in an increase of the temperature of PV cells. Meanwhile, the heat transferred by the PV/T collector can be absorbed by the refrigerant. Then, the superheated refrigerant vapor with low pressure is compressed by the compressor to the high temperature and pressure refrigerant vapor. The condensation heat will be absorbed and stored in the build-in PCM heat storage. The heat transferred by condensation can also be used for producing domestic hot water. The liquid refrigerant will expand through the throttle valve after condensation process, and flow into the $\mathrm{PV} / \mathrm{T}$ collector/evaporator. The heat released from the heat storage module will be used to keep the indoor temperature constant during the night.

(2) Rainy day operating mode: The system will switch to the air source heat pump mode when the solar radiation is insufficient to maintain system operation. The pumps and compressor driven by power grid are used to keep the system work. The air fan heat exchanger is adopted to absorb heat from the ambient air. The refrigerant will be heated by the air fan heat exchanger and compressed by compressor into high temperature and pressure vapor. The heat released by the refrigerant vapor will be transferred to the PCM or water. This mode can make full use of the 
valley electricity to store heat at night, and maintain the indoor temperature through the heat storage module during the day.

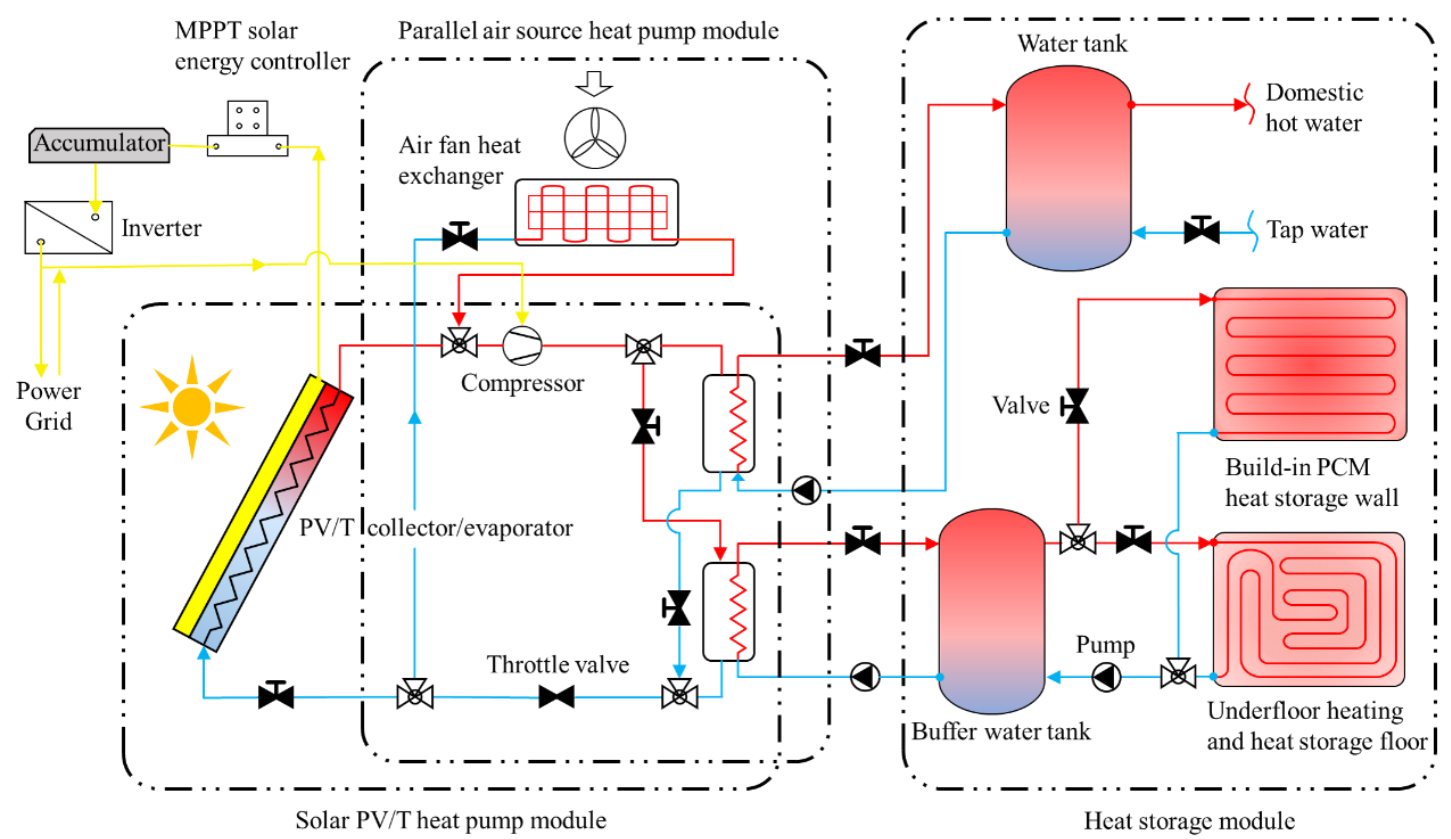

Fig. 1. Schematic of the system based on solar PV/T heat pump.

\section{Mathematical model}

The thermodynamic state points for each process are shown in Fig. 2. The solar PV/T heat pump cycle could be simplified to four components: PV/T collector/evaporator, compressor, PCM heat exchanger and throttle valve. Different temperature $(T)$ and enthalpy $(h)$ at each state point are shown in Fig. 2. $Q_{t h}(\mathrm{~W})$ is the heat transfer rate between refrigerant and the PV/T panel, $Q_{e}$ $(\mathrm{W})$ is the electrical power provided by PV panel, and $Q_{P C M}(\mathrm{~W})$ is the heat transfer rate between refrigerant and phase change materials.

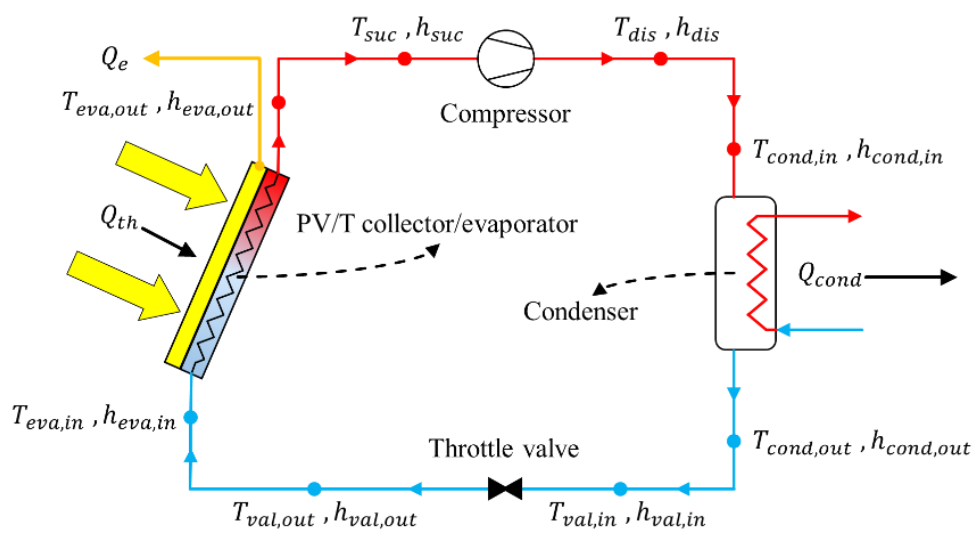

Fig. 2. The thermodynamic state points for each component.

The design parameters of the system and characteristics of different PV/T layers are listed in Table. 1.

Table. 1. Design parameters of the system and characteristics of different PV/T layers.

\begin{tabular}{llll}
\hline Parameters & Nomenclature & Value & Unit \\
\hline & 4 &
\end{tabular}


Thickness of PV-glazing cover

Emissivity of PV-glazing cover

Transmissivity of PV-glazing cover

Thickness of PV cells

Emissivity of PV cells

Absorptance of PV cells

Thermal conductivity of PV cells

Absorptance of PV baseboard

Thickness of EVA grease

Thermal conductivity of EVA grease

Thickness of electrical insulation

Thermal conductivity of electrical insulation

Electrical insulation material

Packing factor

Length of PV/T collector/evaporator

Width of PV/T collector/evaporator

Area of the PV/T collector/evaporator

Thermal conductivity of roll-bond panel

Thickness of roll-bond panel pipe

\begin{tabular}{lll}
$\delta_{g, p v}$ & 1 & $\mathrm{~mm}$ \\
$\varepsilon_{c}$ & 0.84 & {$[-]$} \\
$\tau_{g, p v}$ & 0.9 & {$[-]$} \\
$\delta_{p v}$ & 0.3 & $\mathrm{~mm}$ \\
$\varepsilon_{p}$ & 0.96 & {$[-]$} \\
$a_{p}$ & 0.85 & {$[-]$} \\
$\kappa_{p}$ & 203 & $\mathrm{~W} / \mathrm{m} \cdot \mathrm{K}$ \\
$a_{b}$ & 0.8 & {$[-]$} \\
$\delta_{E V A}$ & 0.5 & $\mathrm{~mm}$ \\
$\kappa_{E V A}$ & 0.311 & $\mathrm{~W} / \mathrm{m} \cdot \mathrm{K}$ \\
$\delta_{e i}$ & 0.5 & $\mathrm{~mm}$ \\
$\kappa_{e i}$ & 0.15 & $\mathrm{~W} / \mathrm{m} \cdot \mathrm{K}$ \\
{$[-]$} & Tedlar & {$[-]$} \\
$\beta_{p}$ & 1 & {$[-]$} \\
$L$ & 2.0 & $\mathrm{~m}$ \\
$W$ & 1.0 & $\mathrm{~m}$ \\
$A$ & 2.0 & $\mathrm{~m} 2$ \\
$\kappa_{r b}$ & 151 & $\mathrm{~W} / \mathrm{m} \cdot \mathrm{K}$ \\
$\delta_{r b}$ & 1 & $\mathrm{~mm}$ \\
$r e f$ & $\mathrm{R} 134 \mathrm{~A}$ & {$[-]$} \\
\hline
\end{tabular}

\subsection{Model of PV/T collector/evaporator}

The heat absorbed by the PV/T panel is expressed as follows:

$$
Q_{a b s}=\left(1-\eta_{e}\right) \cdot A \cdot I \cdot \tau_{g, p v} \cdot\left[\alpha_{p} \cdot \beta_{p}+\alpha_{b} \cdot\left(1-\beta_{p}\right)\right]
$$

where $A$ is the collector area of the PV/T panel $\left(\mathrm{m}^{2}\right) ; I$ is the solar radiation intensity $\left(\mathrm{W} / \mathrm{m}^{2}\right) ; \tau_{g, p v}$ is the transmittances of the PV-glazing cover; $a_{p}$ and $a_{b}$ are the absorption ratios of the PV cells and its baseboard, respectively; $\beta_{p}$ is the packing factor of PV cells; $\eta_{e}$ is the PV cells' efficiency, calculated by (Huide et al., 2017):

$$
\eta_{e}=\eta_{r c} \cdot\left[1-\beta_{p v} \cdot\left(T_{p}-T_{r c}\right)\right]
$$

$\eta_{r c}$ is the reference photovoltaic efficiency value of PV cells at $T_{r c}=298 \mathrm{~K}, \eta_{r c}=0.18 ; \beta_{p v}$ is the temperature coefficient (1/K) of PV cell efficiency, $\beta_{p v}=0.0045$ (Huide et al., 2017).

Fig. 3 shows the heat loss and physical model of PV/T panel which has a multi-layer structure, the heat loss of PV/T panel consists of two parts: (1) heat transfer from PV cells to PV-glazing cover; (2) heat transfer from PV-glazing cover to ambient air.

The total heat loss rate of PV/T module is given as:

$$
Q_{L}=U_{L} \cdot A \cdot\left(T_{p}-T_{a}\right)
$$

where $T_{p}$ and $T_{a}$ are the temperature of PV cells and ambient air, respectively. $U_{L}$ is the overall heat loss coefficient which can be written as:

$$
U_{L}=\left[1 /\left(h_{c v, p-c}+h_{r d, p-c}\right)+1 /\left(h_{c v, c-a}+h_{r d, c-a}\right)\right]^{-1}
$$


$h_{c v, p-c}$ and $h_{r d, p-c}$ are the convective and radiative heat-transfer coefficients between PV cells and glass cover; $h_{c v, c-a}$ and $h_{r d, c-a}$ are the convective and radiative heat-transfer coefficients between glass cover and ambient.

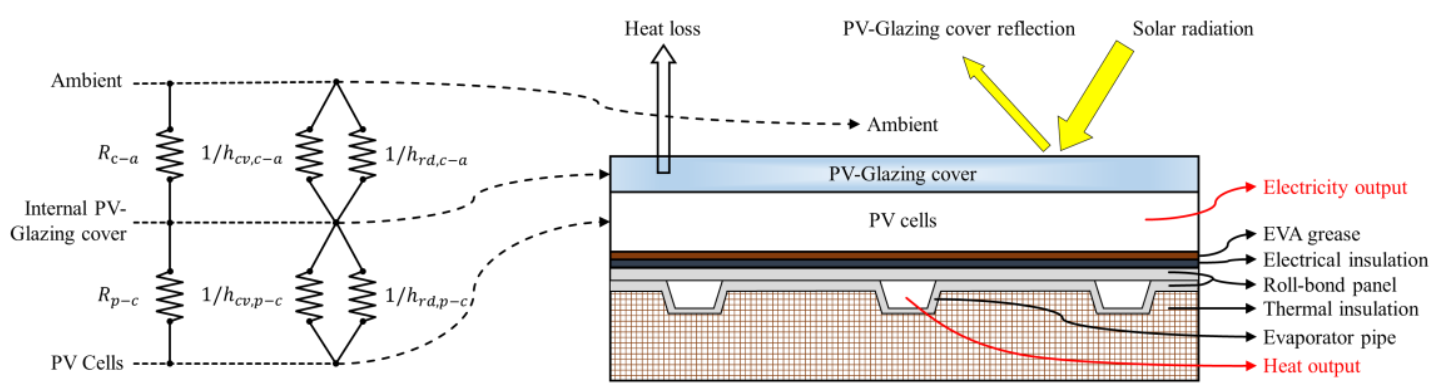

Fig. 3. Heat loss and physical model of PV/T collector/evaporator.

The overall electricity output power of PV cells is given as:

$$
Q_{e}=A \cdot I \cdot \tau_{g, p v} \cdot \alpha_{p} \cdot \beta_{p} \cdot \eta_{e}
$$

Under the steady-state condition, the heat transfer rate delivered by the module equals the rate of the absorbed heat minus the overall heat loss, expressed as:

$$
Q_{t h}=Q_{a b s}-Q_{L}
$$

The total useful solar heat received by the PV/T collector/evaporator is expressed as:

$$
Q_{u}=F_{R} \cdot A \cdot I \cdot \tau_{g, p v} \cdot\left[\alpha_{p} \cdot \beta_{p}+\alpha_{b} \cdot\left(1-\beta_{p}\right)\right]
$$

where $F_{R}$ is the $\mathrm{PV} / \mathrm{T}$ collector thermal efficiency factor, can be defined as (Diallo et al., 2019):

$$
F_{R}=\left(1-\eta_{e}\right) \cdot \frac{1 / U_{L}}{L \cdot W / N_{r b} \cdot\left\{1 /\left(L \cdot U_{L}-\left[\left(W / N_{r b}-L_{r b}\right) F_{r b}+L_{r b} /\left(1+R_{p v} \cdot U_{L}\right)\right]\right)+\sum_{1}^{5} R_{i}\right\}}
$$

$N_{r b}$ is the equivalent number of roll-bond panel pipe; $L_{r b}$ is the equivalent length of roll-bond panel pipe; $\Sigma R i$ is the overall thermal resistance from the PV cells to the PCM; $F_{r b}$ is the efficiency of the roll-bond panel which encapsulated in the backside of the PV/T panel which can be defined as (Diallo et al., 2019):

$$
F_{r b}=\tanh \left[\sqrt{\frac{U_{L}}{\left(k_{r b} \delta_{r b}\left(1+R_{p v} U_{L}\right)\right)}}\left(W / N_{r b}-L_{r b}\right) / 2\right] /\left(\sqrt{\frac{U_{L}}{\left(k_{r b} \delta_{r b}\left(1+R_{p v} U_{L}\right)\right)}}\left(W / N_{r b}-L_{r b}\right) / 2\right)
$$

$\kappa_{r b}$ is the thermal conductivity of roll-bond panel; $\delta_{r b}$ is the thickness of the roll-bond panel pipe; $R_{p v}$ is the thermal resistance of PV cells.

The thermal resistances of the PV/T system and heat transfer along the system are shown in Fig. 4. 


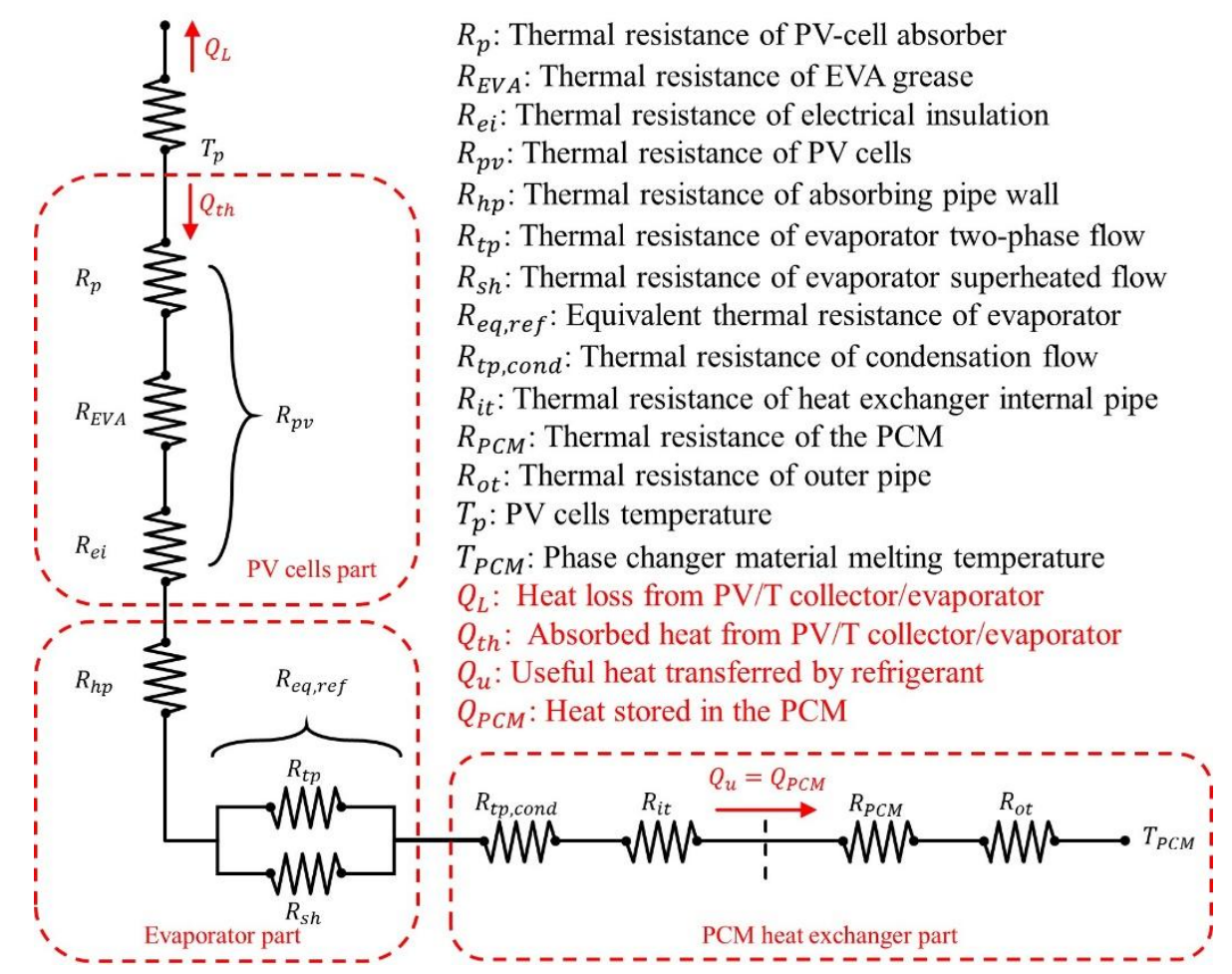

Fig. 4. Thermal resistances of the PV/T system and heat transfer along the system.

Heat transfer between PV module and heat pipe is a conventional one dimensional heat conduction process and its associated thermal resistance is:

$$
R_{p v}=\delta_{p} / k_{p}+\delta_{E V A} / k_{E V A}+\delta_{e i} / k_{e i}
$$

Superheated region and two-phase region existed in the refrigerant side of the PV/T collector/evaporator. The equivalent thermal resistance of the two different regions can be calculated as (P. Hartnett and M. Rohsenow, 1973):

$$
R_{e q, r e f}=\left(1 / R_{t p}+1 / R_{s h}\right)^{-1}
$$

\subsection{Model of build-in PCM heat storage}

All the heat gained by the build-in PCM heat storage is transferred by the PCM heat exchanger. The heat store rate in the PCM and concrete is expressed as follows:

$$
Q_{P C M}+Q_{\text {conc }}=m_{\text {ref }}^{\cdot} \cdot\left(h_{d i s}-h_{i n}\right)
$$

The PCM melting rate is calculated by:

$$
\dot{m}=Q_{P C M} / \triangle H_{P C M}
$$

where $\Delta H_{P C M}$ is the latent heat of the PCM $(\mathrm{kJ} / \mathrm{kg})$.

Fig. 5 shows the phase change temperature of 15 kinds of phase change materials including organic/inorganic/eutectic compounds materials. According to L.F. Cabeza et al. (Cabeza et al., 2011), the recommendation phase change temperature range for underfloor heating is between $30{ }^{\circ} \mathrm{C}$ to $40{ }^{\circ} \mathrm{C}$. There are five kinds of PCM that have phase change temperature in this range: 

decahydrate, Sodium phosphate dibasic dodecahydrate.

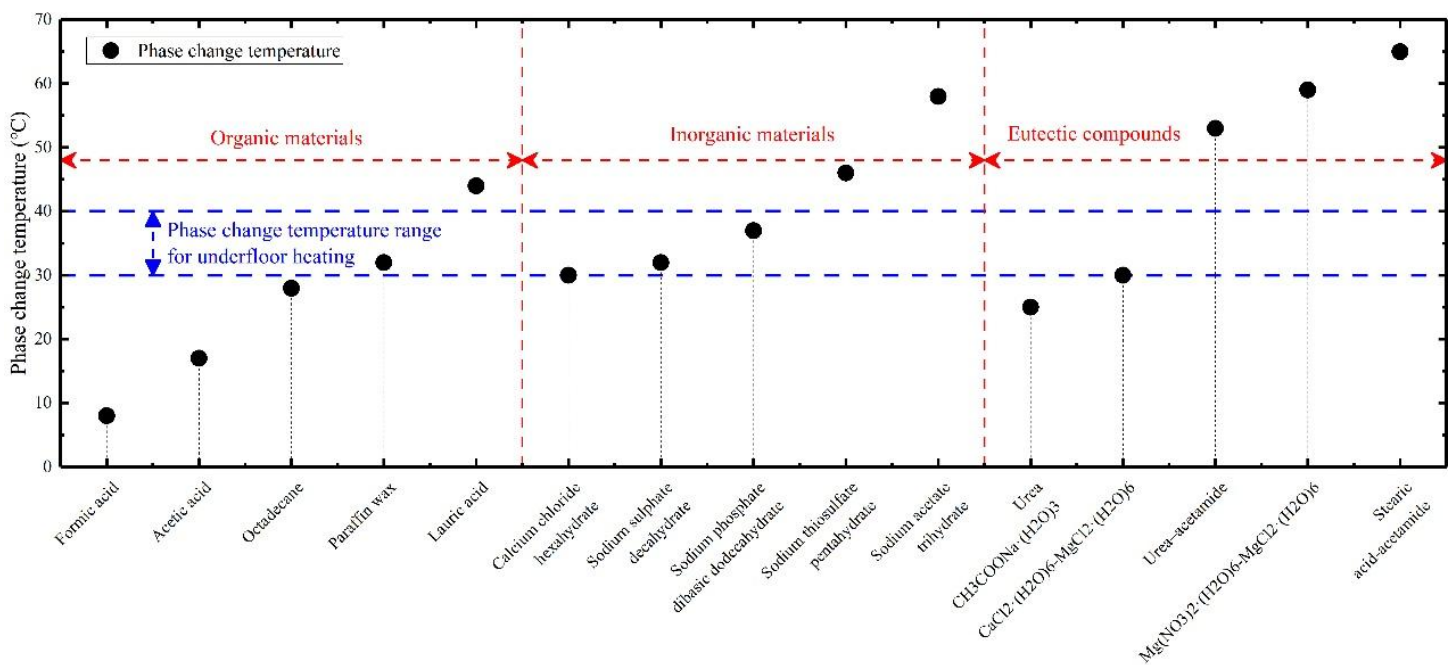

Fig. 5. Phase change temperature of 15 kinds of PCM including Organic/Inorganic/Eutectic compounds materials.

The variation curve of floor temperature with phase change temperature and the comparison of three indices including thermal conductivity, latent heat and price (Pereira da Cunha and Eames, 2016) of above five kinds of PCM are shown in Fig. 6. These five materials have different phase change temperature which all in the recommendation temperature range for underfloor heating. The ideal material should have a higher thermal conductivity and latent heat while the price is low. In order to evaluate these five materials, the graph of ideal material is also plotted in Fig. 6. The organic and eutectic compounds phase change materials have a higher price than inorganic materials while the thermal conductivity and latent heat are lower. Moreover, the larger of the overlap area in Fig. 6 between each material and ideal material, the better of the material performance. As shown in Fig. 6, Sodium phosphate dibasic dodecahydrate has the largest overlap area, thus, it is used in the simulation of build-in PCM heat storage unit.

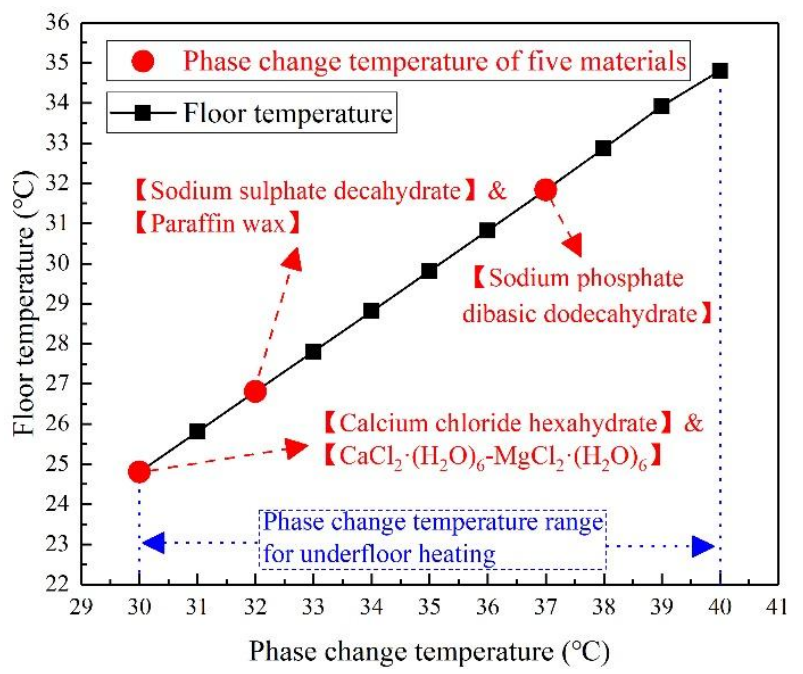




\section{Thermal conductivity $(\mathrm{W} / \mathrm{m} \cdot \mathrm{K})$}

Price $(f / \mathrm{m} 3)$

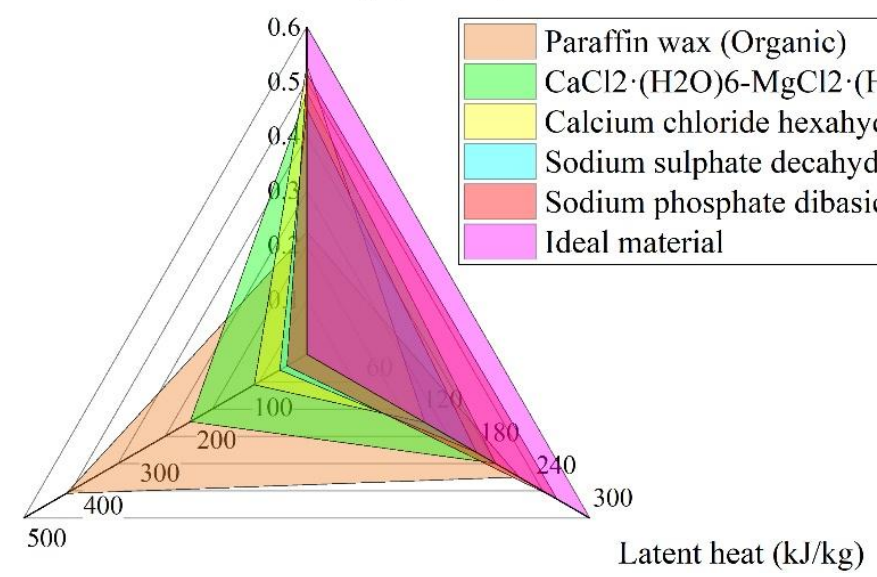

(b)

Fig. 6. (a) Variation curve of floor temperature with phase change temperature. (b) Thermal conductivity/Latent heat/Price comparison of six kinds of materials including ideal material.

Fig. 7 illustrates the structure and cross-section view of a build-in PCM heat storage unit which is the component of underfloor heating module. The phase change materials (Sodium phosphate dibasic dodecahydrate) are placed in the outer tube of a double-wall tube which can store heat during the day and release latent heat at night. Polystyrene board and foam concrete are used as thermal insulation and building materials, respectively. The hot water which produced by solar PV/T heat pump module is pumped into the pipe of underfloor heating to keep the indoor temperature steady. The properties of PCM (Jankowski and McCluskey, 2014) and concrete as well as underfloor heating working conditions are listed in Table. 2.

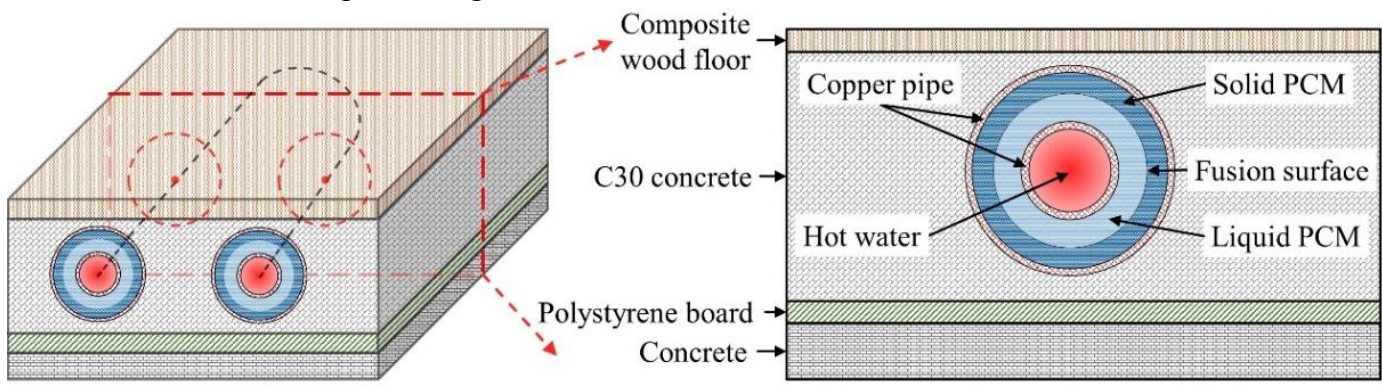

Fig. 7. Structure and cross-section view of the build-in PCM heat storage unit.

Table. 2. Properties of PCM and concrete as well as underfloor heating working conditions.

\begin{tabular}{|c|c|c|c|}
\hline Parameters & Nomenclature & Value & Unit \\
\hline Type of PCM & {$[-]$} & $\mathrm{Na}_{2} \mathrm{HPO}_{4} \cdot 12 \mathrm{H}_{2} \mathrm{O}$ & {$[-]$} \\
\hline Latent heat of PCM & $\Delta H_{P C M}$ & 265 & $\mathrm{~kJ} / \mathrm{kg}$ \\
\hline Density of PCM & $\rho_{P C M}$ & 1507 & $\mathrm{~kg} / \mathrm{m}^{3}$ \\
\hline Temperature of transition of PCM & $T_{m e l}$ & 37 & ${ }^{\circ} \mathrm{C}$ \\
\hline $\begin{array}{l}\text { Specific heat at constant pressure of } \\
\text { PCM }\end{array}$ & $C_{p-P C M}$ & 1.69 & $\mathrm{~kJ} / \mathrm{kg} \cdot \mathrm{K}$ \\
\hline Thermal conductivity of PCM & $\kappa_{P C M}$ & 0.514 & $\mathrm{~W} / \mathrm{m} \cdot \mathrm{K}$ \\
\hline Thermal conductivity of copper coil & $\kappa_{C}$ & 397 & $\mathrm{~W} / \mathrm{m} \cdot \mathrm{K}$ \\
\hline
\end{tabular}




\begin{tabular}{llll}
$\begin{array}{l}\text { Type of concrete } \\
\begin{array}{l}\text { Specific heat at constant pressure of } \\
\text { concrete }\end{array}\end{array}$ & $\begin{array}{l}C_{p-c o n c} \\
\text { Thermal conductivity of concrete }\end{array}$ & 0.97 & {$[-]$} \\
$\begin{array}{l}\text { Density of concrete } \\
\text { Thickness of the concrete }\end{array}$ & $\kappa_{c o n}$ & 1.6 & $\mathrm{~kJ} / \mathrm{kg} \cdot \mathrm{K}$ \\
Thickness of the wood floor & $\delta_{c o n}$ & 2300 & $\mathrm{~W} / \mathrm{m} \cdot \mathrm{K}$ \\
Volume flow rate of circulating water & $\delta_{\text {floor }}$ & 0.13 & $\mathrm{~kg} / \mathrm{m}^{3}$ \\
\hline
\end{tabular}

Fig. $8(\mathrm{a} \sim \mathrm{c})$ presents the simulation results of heat transfer in build-in PCM heat storage unit at different time which carried out by software of Ansys Fluent 17.0. The thermal conductivity of the heat transfer between the coil and PCM has been considered in the setup of the boundary conditions. Thus, the boundary conditions of inner and outer tube have been set as "coupled" in Ansys Fluent 17.0 which means the solution of heat transfer process would be carried out through the coupled method in the program. The initial temperature of the heat storage unit is $15^{\circ} \mathrm{C}$, and the underfloor heating can reach above $30^{\circ} \mathrm{C}$ after 39 hours when the circulating water is $40^{\circ} \mathrm{C}$. As shown in Fig. 8(d), the floor temperature increases with time and reaches $25^{\circ} \mathrm{C}$ in the first 12 hours which has $10^{\circ} \mathrm{C}$ difference with the ambient. The changing curve mountains rapidly in the initial stage and becomes steady after 39 hours, the build-in PCM heat storage would supply heat to indoor area and maintain the room temperature.

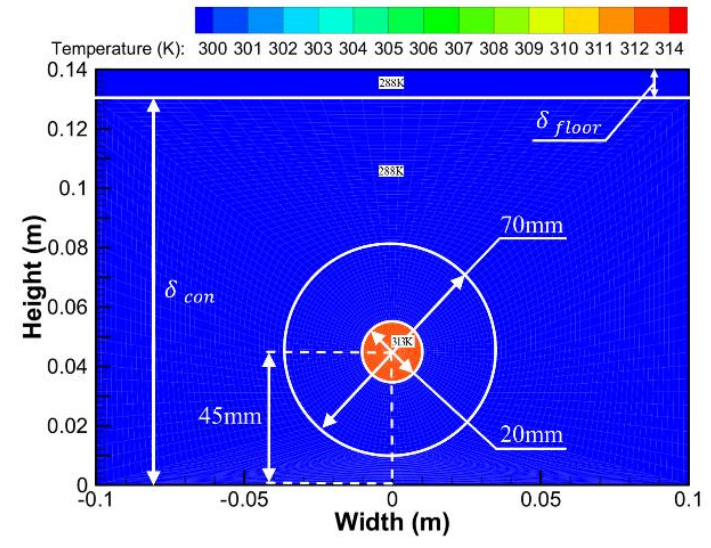

(a) Initial stage

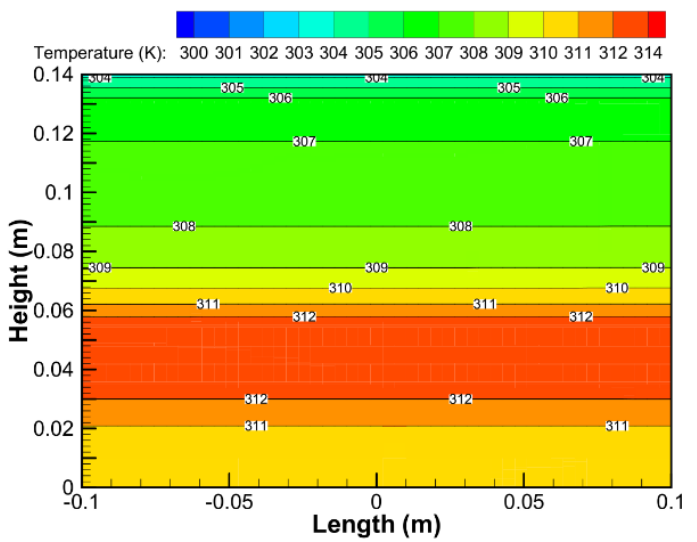

(c) Cross-section view at the width of 0 (steady stage)

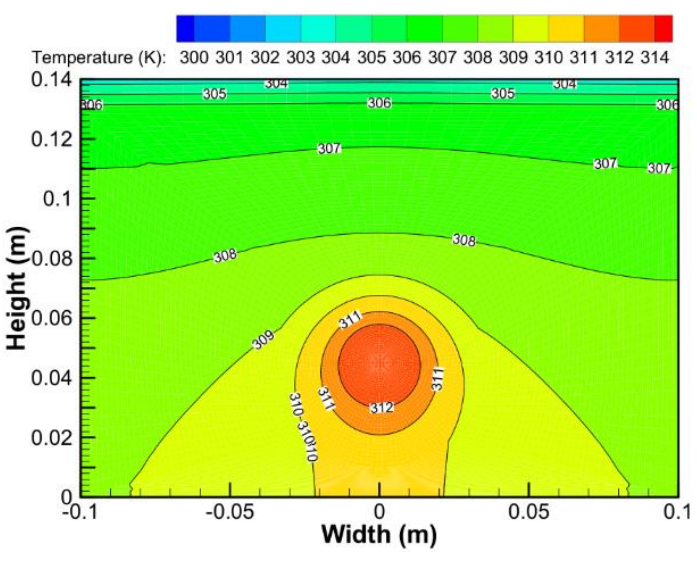

(b) Steady stage

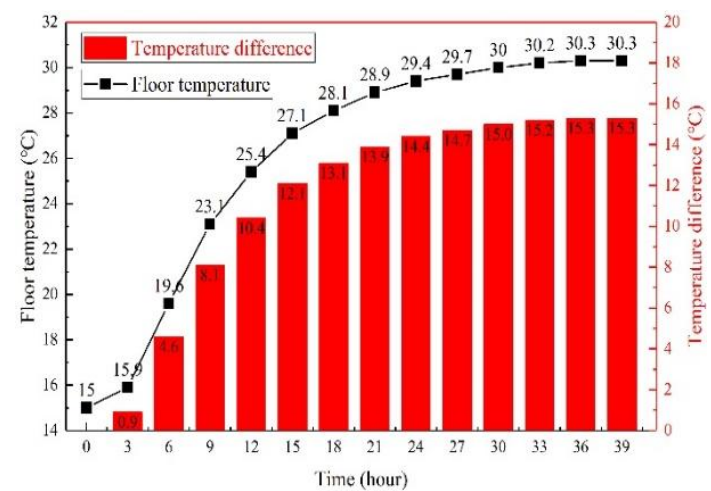

(d) 
Fig. 8. (a c) Cross-section temperature contour of the build-in PCM heat storage unit at initial and steady stage. (d) Variation curve of floor temperature and temperature difference between floor and ambient.

Fig. 9 shows the variation curves of circulating water temperature and floor temperature with the length of circulating water tube. The temperature of circulating water would decrease from $40{ }^{\circ} \mathrm{C}$ (inlet) to $32.5^{\circ} \mathrm{C}$ (outlet) while the floor temperature varies from $30.4^{\circ} \mathrm{C}$ to $22.9^{\circ} \mathrm{C}$. This figure also presents the three temperature range of underfloor heating which can divided into three categories: Temperature range of no person staying area $\left(29^{\circ} \mathrm{C}-35^{\circ} \mathrm{C}\right)$, Temperature range of short-time staying area $\left(25^{\circ} \mathrm{C}-29^{\circ} \mathrm{C}\right)$ and Temperature range of long-time staying area $\left(20^{\circ} \mathrm{C}-25^{\circ} \mathrm{C}\right)$. Therefore, when using build-in PCM heat storage as underfloor heating, the system could meet the heat demand of users and keep indoor temperature steady.

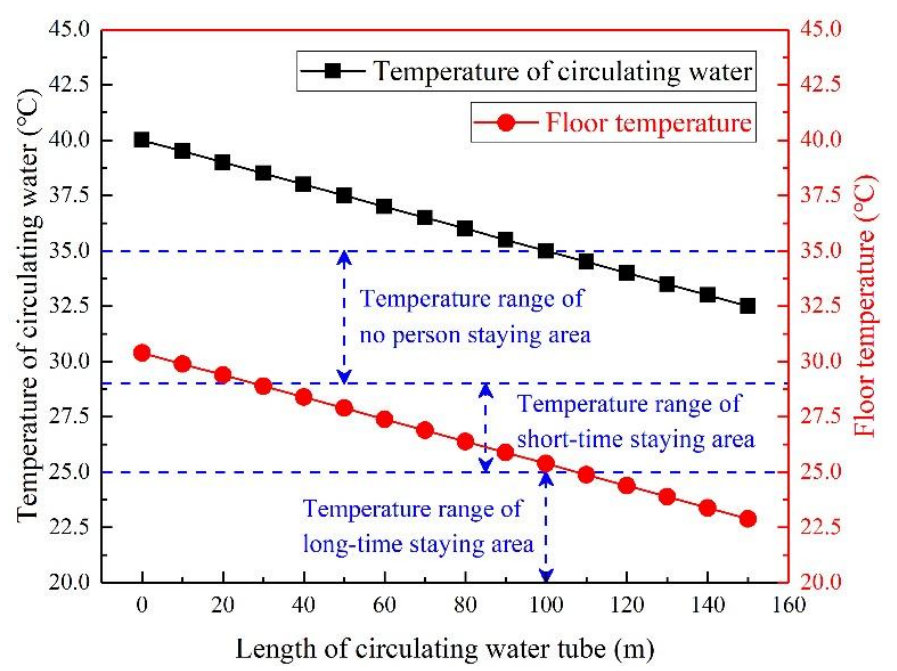

Fig. 9. Variation curves of circulating water temperature and floor temperature with the length of circulating water tube.

\subsection{Model of compressor}

The refrigerant mass flow rate $m_{r e f}^{\bullet}$ could be calculated by (Ma, 2013)

$$
m_{r e f}^{\bullet}=\lambda \cdot V_{t h} / v_{\text {suc }}
$$

where the $\lambda$ is the compressor volumetric efficiency, $V_{t h}$ is the theoretical displacement volume of compressor $\left(\mathrm{m}^{3}\right), v_{s u c}$ is the specific volume of the refrigerant in the suction period $\left(\mathrm{m}^{3} / \mathrm{kg}\right)$.

The power consumption of compressor is written as:

$$
P_{\text {com }}=m_{\text {ref }} \cdot\left(h_{\text {dis }}-h_{\text {suc }}\right) / \eta_{\text {ele }}
$$

where $\eta_{e l e}$ is the efficiency of the compressor which can be expressed by (Ma, 2013):

$$
\eta_{\text {ele }}=-0.17938+0.87501 \frac{p_{\text {dis }}}{p_{\text {suc }}}-0.30014\left(\frac{p_{\text {dis }}}{p_{\text {suc }}}\right)^{2}+0.04135\left(\frac{p_{\text {dis }}}{p_{\text {suc }}}\right)^{3}-0.00206\left(\frac{p_{\text {dis }}}{p_{\text {suc }}}\right)^{4}
$$


The refrigerant vapor through compressor is isentropic, thus the equation can be expressed by:

$$
T_{d i s} / T_{\text {suc }}=\left(p_{\text {dis }} / p_{\text {suc }}\right)^{(\chi-1) / \chi}
$$

where the $\chi$ is the polytropic index of refrigerant. $h_{d i s}$ is the enthalpy of the vapor after compressed (kJ/kg), $h_{\text {suc }}$ is the enthalpy of the vapor before compressed $(\mathrm{kJ} / \mathrm{kg})$.

The heat of refrigerant absorbed from the $\mathrm{PV} / \mathrm{T}$ collector/evaporator equal to $Q_{u}$ :

$$
m_{\mathrm{ref}} \cdot\left(h_{\mathrm{eva}, \text { out }}-h_{\mathrm{eva}, \mathrm{in}}\right)=Q_{u}=Q_{\mathrm{th}}
$$

\subsection{Definition of the system performance}

The COP (Coefficient of Performance) of the system can be defined as the ratio of overall heat output of system and power consumption of the compressor as following (R. Turns, 2006)

$$
\mathrm{COP}=m_{\text {ref }}^{\cdot} \cdot\left(h_{\text {cond , in }}-h_{\text {cond }, \text { out }}\right) / P_{\text {com }}
$$

The $\eta_{t h}$ is the PV/T collector/evaporator's thermal efficiency, which can be defined as:

$$
\eta_{t h}=Q_{t h} /(A \cdot I)
$$

The $\eta_{e}$ is the PV cells electrical efficiency which can be defined as:

$$
\eta_{e}=Q_{e} /(A \cdot I)
$$

The $\eta_{\text {ove }}$ is the overall efficiency which can be defined as:

$$
\eta_{\text {ove }}=\left(Q_{\text {cond }}+Q_{e}\right) /(A \cdot I)
$$

\subsection{Presentation of the algorithm by flow chart}

The numerical simulation procedure of the system is shown in Fig. 10 to predict the system performance using the software of MATLAB. The solution steps are as flows:

(1) Input all the environmental parameters, such as solar radiation intensity, wind speed, ambient temperature, etc.

(2) Input the system design parameters and operation parameters, such as collector area, packing factor, collector slop, transmissivity of external glass cover, PV-glazing cover, thickness of each layer, etc.

(3) Assume the temperature of PV cells $T_{p}$.

(4) Calculate the overall heat loss rate $Q_{L}$, and the PV electrical output power $Q_{e}$.

(5) Calculate the thermal energy gain rate through PV/T collector/evaporator $Q_{t h}$, and the useful heat transfer rate by refrigerant $Q_{u}$.

(6) Calculate $\left(Q_{t h^{-}} Q_{u}\right) / Q_{t h}$. If $\left|\left(Q_{t h^{-}} Q_{u}\right) / Q_{t h}\right|<0.1 \%$, the system achieves the heat balance and move to next step.

(7) Input the superheat degree $T_{\text {sh }}$.

(8) Assume the compressor discharge pressure $P_{d i s}$.

(9) Calculate the PV/T collector/evaporator inlet enthalpy $h_{\text {eva,in }}$ and the PCM heat exchanger outlet enthalpy $h_{\text {cond,out }}$. If $\left|\left(h_{\text {eva,in }}-h_{\text {cond,out }}\right) / h_{\text {cond,out }}\right|<0.1 \%$, the system achieves the 
pressure balance and move to next step.

(10)Calculate the COP, PCM melting rate $\dot{m}$, thermal efficiency $\eta_{t h}$, electrical efficiency $\eta_{e}$, and overall efficiency $\eta_{\text {ove }}$.

(11)Results output, and stop the program.

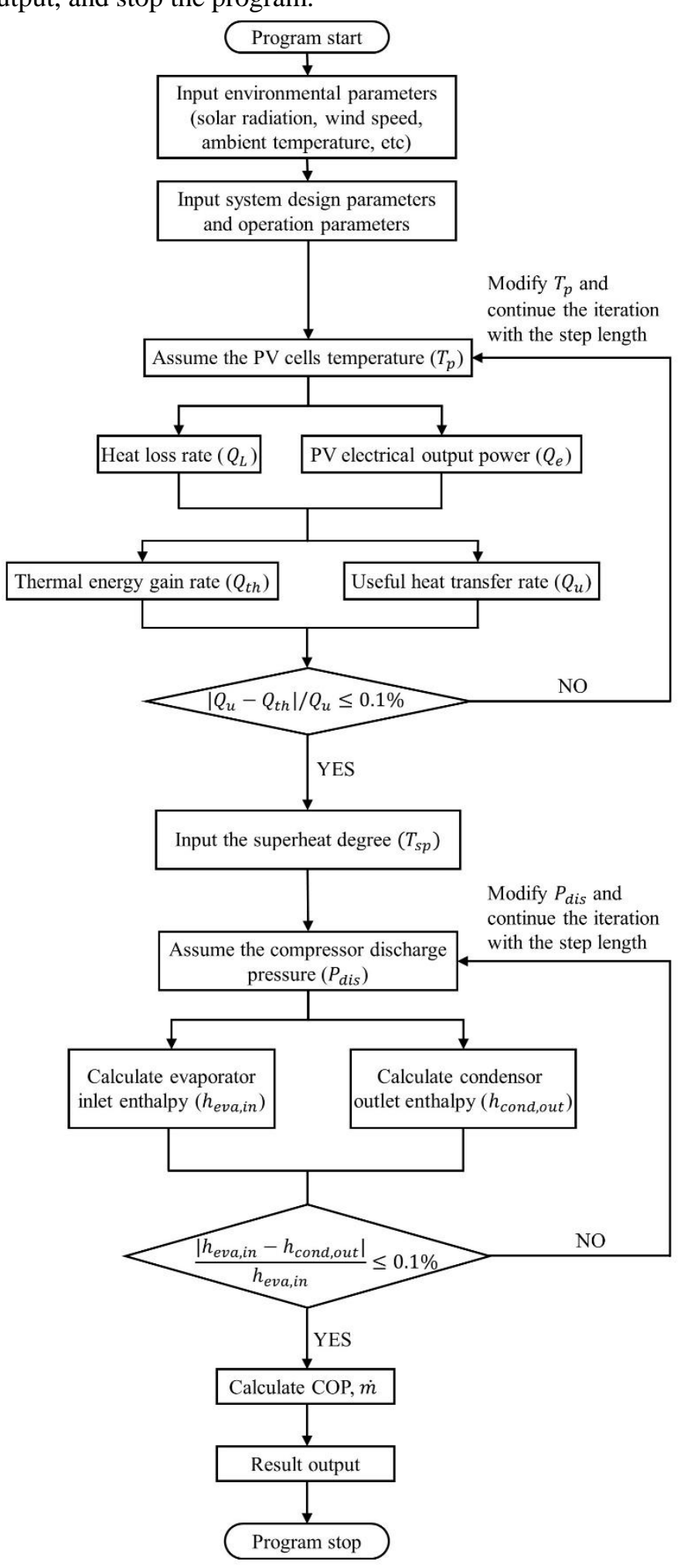

Fig. 10. Numerical solution procedure of the system. 
To ensure the reliability of the mathematic model, the simulation results should be compared with the experimental results. The experimental parameters used in the simulation are listed in Table. 3.

Table. 3. Experimental parameters (Zhou et al., 2019).

\begin{tabular}{llll}
\hline Parameters & Nomenclature & Value & Unit \\
\hline Thickness of glass cover & $\delta_{g}$ & 3.2 & $\mathrm{~mm}$ \\
Thickness of air gap & $\delta_{\text {air }}$ & 35 & $\mathrm{~mm}$ \\
Thickness of PV-glazing cover & $\delta_{g, p v}$ & 1 & $\mathrm{~mm}$ \\
Thickness of PV cells & $\delta_{p v}$ & 0.2 & $\mathrm{~mm}$ \\
Thickness of EVA adhesive film & $\delta_{E V A}$ & 0.4 & $\mathrm{~mm}$ \\
Thickness of electrical insulation & $\delta_{e i}$ & 0.5 & $\mathrm{~mm}$ \\
Length of PV/T & $L$ & 3.0 & $\mathrm{~m}$ \\
Width of PV/T & $W$ & 1.6 & $\mathrm{~m}$ \\
Wind speed & $v_{\text {wind }}$ & 1.5 & $\mathrm{~m} / \mathrm{s}$ \\
Ambient temperature & $T_{a}$ & 298.5 & $\mathrm{~K}$ \\
Refrigerant type & $r e f$ & $\mathrm{R} 22$ & {$[-]$} \\
Packing factor & $\beta_{p}$ & 0.64 & {$[-]$} \\
\hline
\end{tabular}

The comparison results of heating COP are presented in Fig. 11(a), the operating conditions are refer from Zhou et al.(Zhou et al., 2019). Under the same system components (PV/T collector/evaporator, compressor, condenser, expansion valve, water tank), the simulation results are in good agreement with the experimental results. Heating COP of the PV/T system increases in the first 15 minutes because the water in the tank still in the low temperature range. Thus, the temperature differences between the refrigerant fluid and water remains large in the condenser leading to a high heat transfer efficiency. However, the heat transfer efficiency of the condenser would be decreased when the temperature of the inlet water rises up during the operation of the whole system. That is the reason of the reduction of heating COP after 15 minutes. The average error of heating COP is $2.84 \%$ while the maximum error is $5.12 \%$. Fig. 11(b) presents the experimental and simulation results of the photovoltaic efficiency. The maximum photovoltaic efficiency is $10.11 \%$ while the minimum is $8.09 \%$, but all the experimental photovoltaic efficiencies fluctuate around $9.24 \%$. The simulation photovoltaic efficiencies remain around $9.25 \%$ but fluctuate from $9.01 \%$ to $9.7 \%$ due to the influence of solar radiation intensity. The average error of photovoltaic efficiency is $4.48 \%$ while the maximum error is $9.30 \%$.
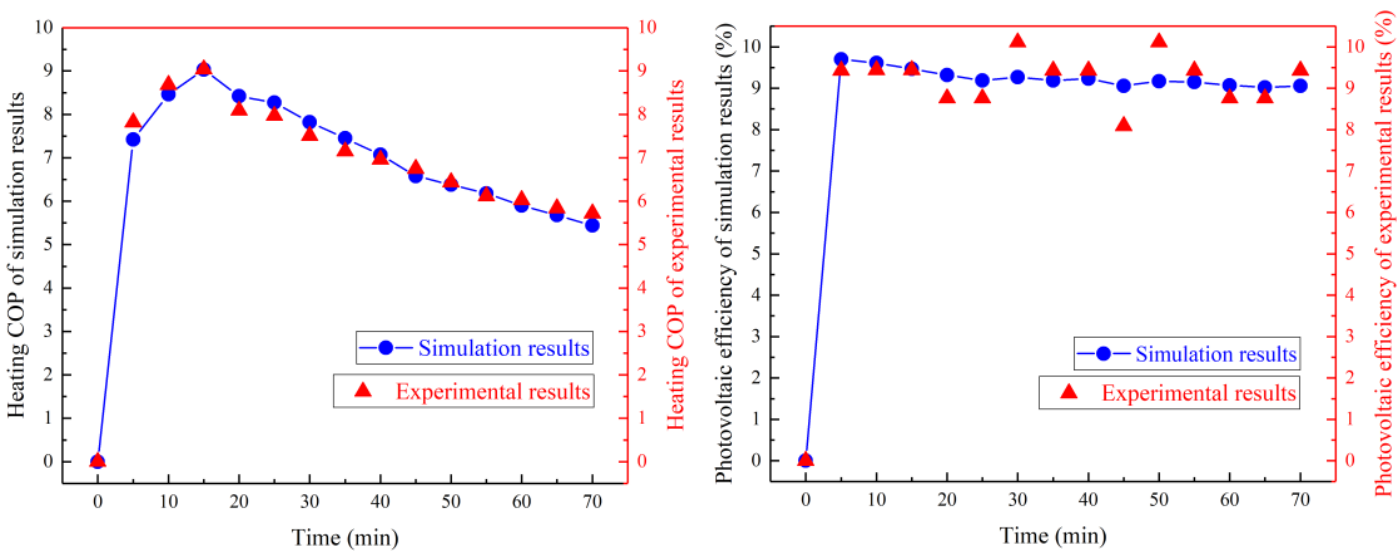
Fig. 11. (a) Comparison results of experimental and simulated heating COP. (b) Comparison results of experimental and simulated photovoltaic efficiency.

\section{Parameter analysis}

In this section, the influences of different parameters (solar radiation intensity, ambient temperature, wind speed, area of $\mathrm{PV} / \mathrm{T}$ collector) on this system are investigated, and the performance indices of the system under typical working conditions are also given. It should be noted that when one parameter is varied, others keep constant. Pressure ratio of the compressor refers the ratio of pressure of discharged refrigerant vapor and charged refrigerant vapor.

\subsection{Solar radiation intensity}

The influences of solar radiation intensity which varying from $200 \mathrm{~W} / \mathrm{m}^{2}$ to $1000 \mathrm{~W} / \mathrm{m}^{2}$ are shown as follows at the working conditions are: ambient temperature is $25^{\circ} \mathrm{C}$, wind speed is 1.5 $\mathrm{m} / \mathrm{s}$ and area of PV/T collector is $2 \mathrm{~m}^{2}$.

Fig. 12 presents the rising curve of the heating COP and declining curves of thermal, electrical and overall efficiencies. The heating COP is 3.0 for a solar radiation of $200 \mathrm{~W} / \mathrm{m}^{2}$, and it can reach up to 10.8 when the solar radiation is $1000 \mathrm{~W} / \mathrm{m}^{2}$. The refrigerant evaporation temperature and pressure will be increased due to a higher temperature of PV cells. Thus, the compressor consumes less electricity to compress the refrigerant vapor leading to this upward trend. Meanwhile, the heat loss will mount due to a higher temperature difference between PV cells and ambient. Thereby, the thermal and electrical efficiencies of the PV/T panel reduce resulting in a reduction of the overall efficiency.

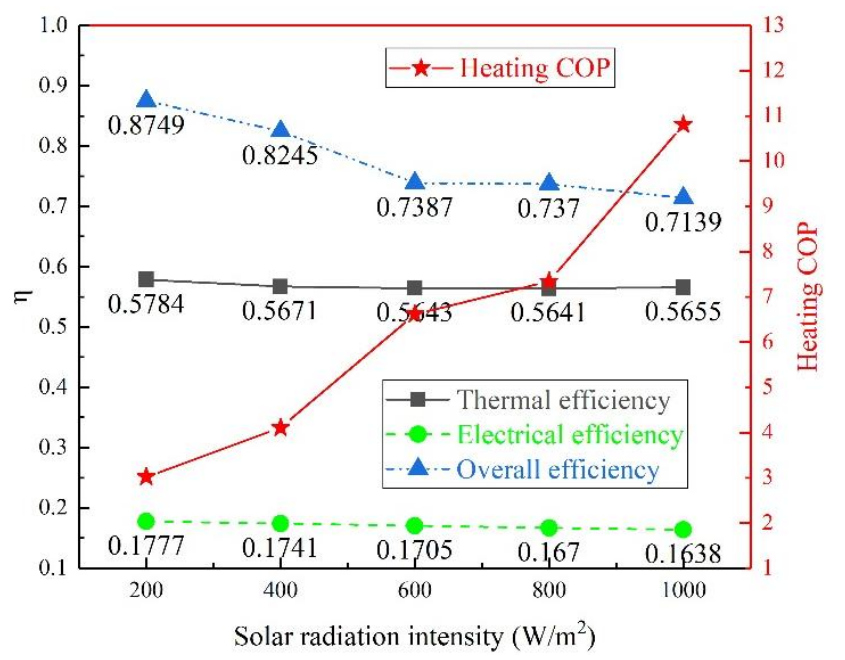

Fig. 12. Influence of solar radiation intensity on heating COP and thermal, electrical, overall efficiencies.

Fig. 13 shows the effect of solar radiation intensity on thermal and electrical output power, pressure ratio and mass flow rate of refrigerant. The thermal and electrical power keep mounting with the increase of the solar radiation intensity. Meanwhile, the pressure ratio of the compressor decreases and the mass flow rate of the refrigerant increases. That is because the increase of the 
evaporation temperature causes a higher evaporation pressure which equals to the suction pressure of compressor leading to a lower pressure ratio. Furthermore, a larger amount of refrigerant will be needed to transfer extra heat from PV/T collector/evaporator to PCM heat exchanger (condenser) when the PV/T panel absorbs more heat from solar radiation.

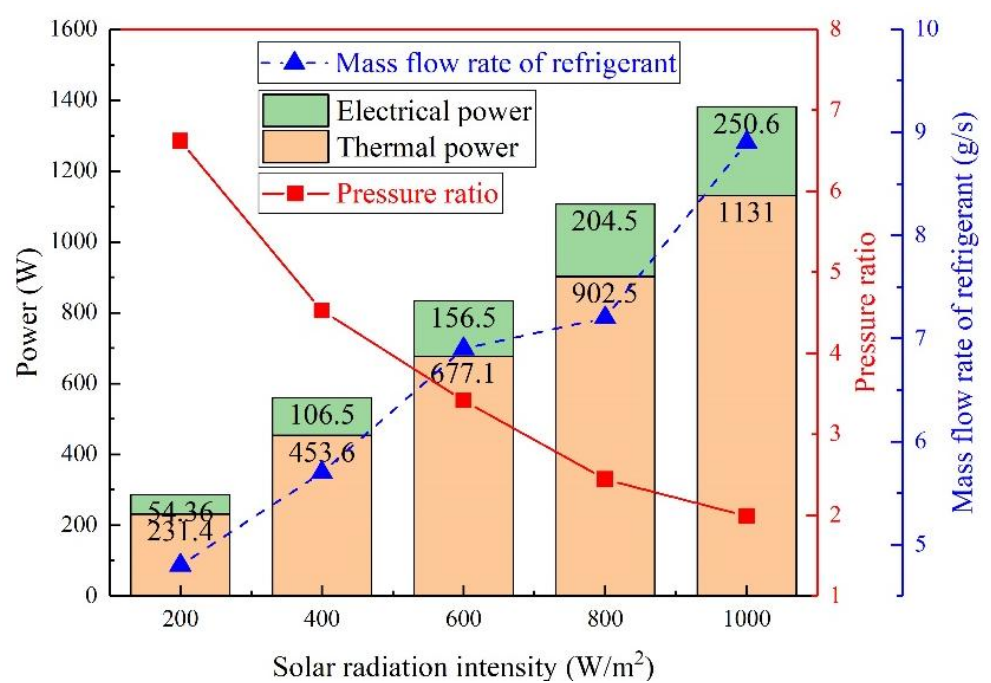

Fig. 13. Influence of solar radiation intensity on electrical and thermal power, pressure ratio and mass flow rate of refrigerant.

As shown in Fig. 14, there is a positive linear correlation between PV cells' electrical power generation and solar radiation intensity while the consumption power of compressor fluctuates around $120 \mathrm{~W}$. When the output power to grid is less than zero, it means the system consumes electricity from the power grid. The electrical power generated by PV panels could meet the demand of the compressor and the system could output electricity to power grid when the solar radiation intensity exceeds $500 \mathrm{~W} / \mathrm{m}^{2}$.

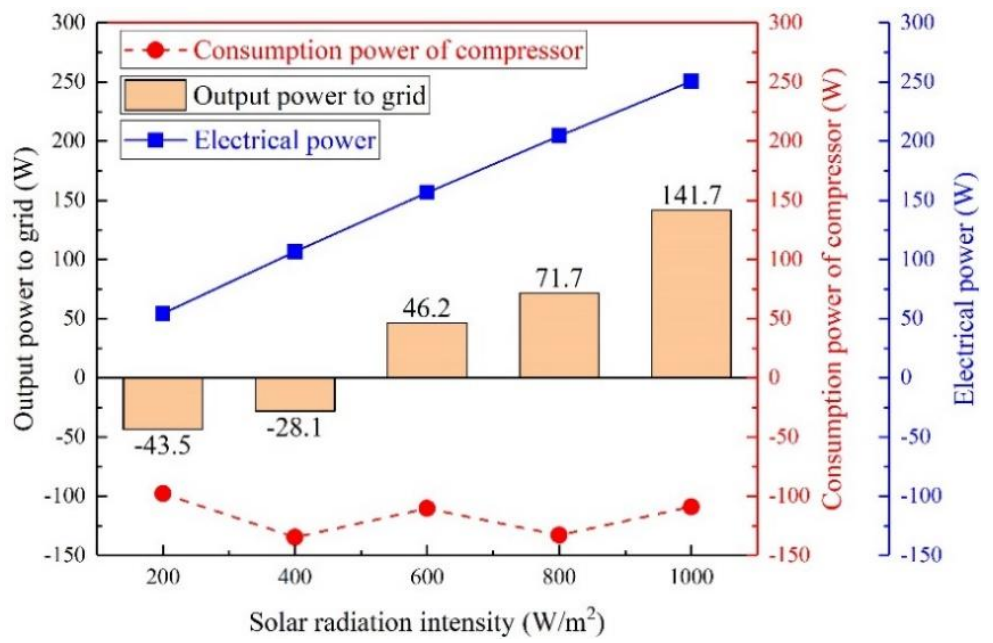

Fig. 14. Influence of solar radiation intensity on electrical power, consumption power of compressor and output power to grid.

\subsection{Ambient temperature}

The influences of ambient temperature which varying from $15{ }^{\circ} \mathrm{C}$ to $35{ }^{\circ} \mathrm{C}$ are shown as follows at the working conditions are: solar radiation intensity is $600 \mathrm{~W} / \mathrm{m}^{2}$, wind speed is $1.5 \mathrm{~m} / \mathrm{s}$ 
and area of PV/T collector is $2 \mathrm{~m}^{2}$.

Fig. 15 shows that increasing the ambient temperature will increase the heating COP and thermal efficiency but decrease the electrical and overall efficiencies. The temperature difference between PV cells and ambient will reduce when the ambient temperature rises leading to a less heat loss from PV/T panel to the surrounding. Thus, the heating COP increases and the electrical efficiency decreases due to a higher temperature of the PV cells while the thermal efficiency increases. However, the electrical efficiency outweighs the thermal efficiency resulting in a reduction of the overall efficiency when the ambient temperature is below $25^{\circ} \mathrm{C}$ The heating COP (9.25) at $35{ }^{\circ} \mathrm{C}$ is higher than $\mathrm{COP}(5.79)$ at $15{ }^{\circ} \mathrm{C}$ by $59.8 \%$, thus a higher ambient temperature is better for the system performance.

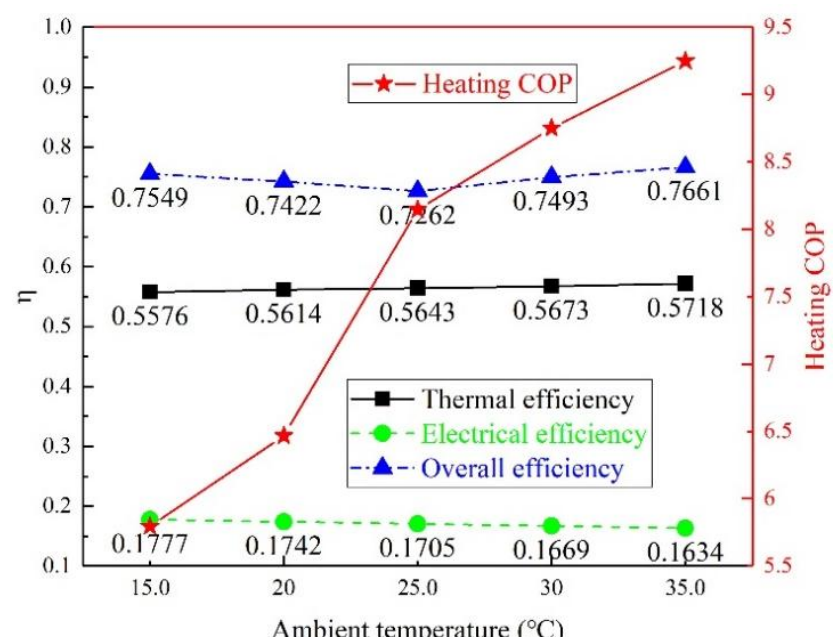

Fig. 15. Influence of ambient temperature on heating COP and thermal, electrical, overall efficiencies.

The variation curves of thermal and electrical power, pressure ratio and mass flow rate of refrigerant with the increase of ambient temperature are shown in Fig. 16. The changing curves of the electrical and thermal output power are the same as the electrical and thermal efficiencies. The pressure ratio of the compressor will increase when the ambient temperature is below $25^{\circ} \mathrm{C}$ and decrease when the ambient temperature is over $25^{\circ} \mathrm{C}$ That is because a lower ambient temperature leads to a lower superheat degree of refrigerant which cause a lower pressure ratio, and in the opposite, a higher ambient temperature leads to a higher superheat degree. Moreover, when the ambient temperature exceeds $25^{\circ} \mathrm{C}$, it will influence the thermal efficiency of PV/T collector causing the reduction of pressure ratio. The mass flow rate of the refrigerant will keep climbing when the ambient temperature rises because less heat will lose in the ambient while more heat will be absorbed by refrigerant. 


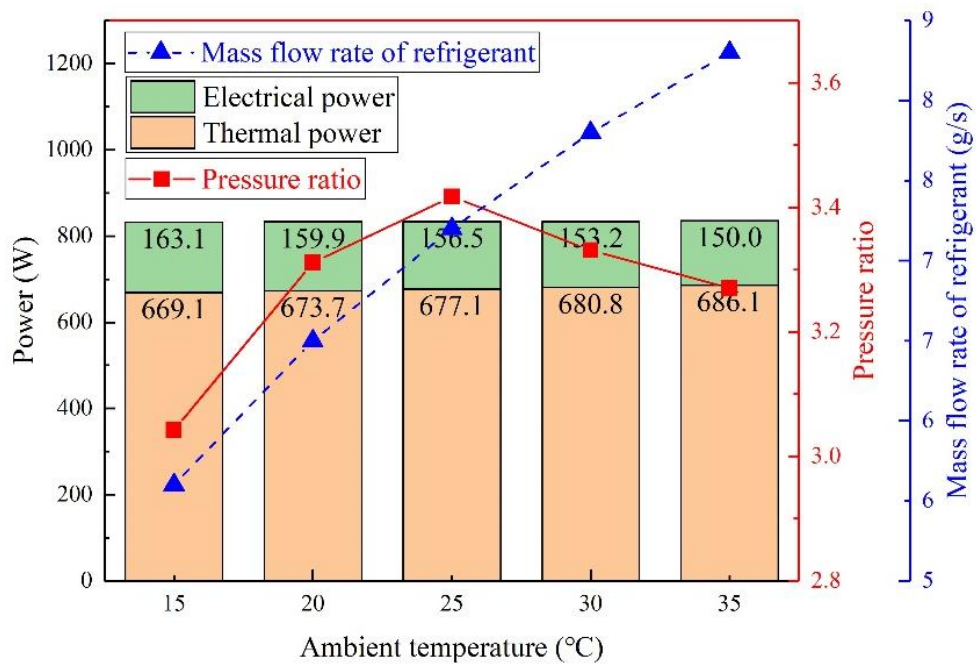

Fig. 16. Influence of ambient temperature on electrical and thermal power, pressure ratio and mass flow rate of refrigerant.

As shown in Fig. 17, the electrical power of PV decreases linearly with the ambient temperature while the consumption power of compressor decreases when the ambient temperature is below $25^{\circ} \mathrm{C}$ and increases when the ambient temperature exceeds $25^{\circ} \mathrm{C}$. The output power to grid reaches its maximum at $25{ }^{\circ} \mathrm{C}$. Because when the ambient temperature is below $25{ }^{\circ} \mathrm{C}$, the effect of environmental heat loss is greater than that of heat-collecting efficiency due to a large temperature difference. However, the effect of a higher ambient temperature on heat-collecting efficiency is greater than that of environmental heat loss when the ambient temperature exceeds $25^{\circ} \mathrm{C}$

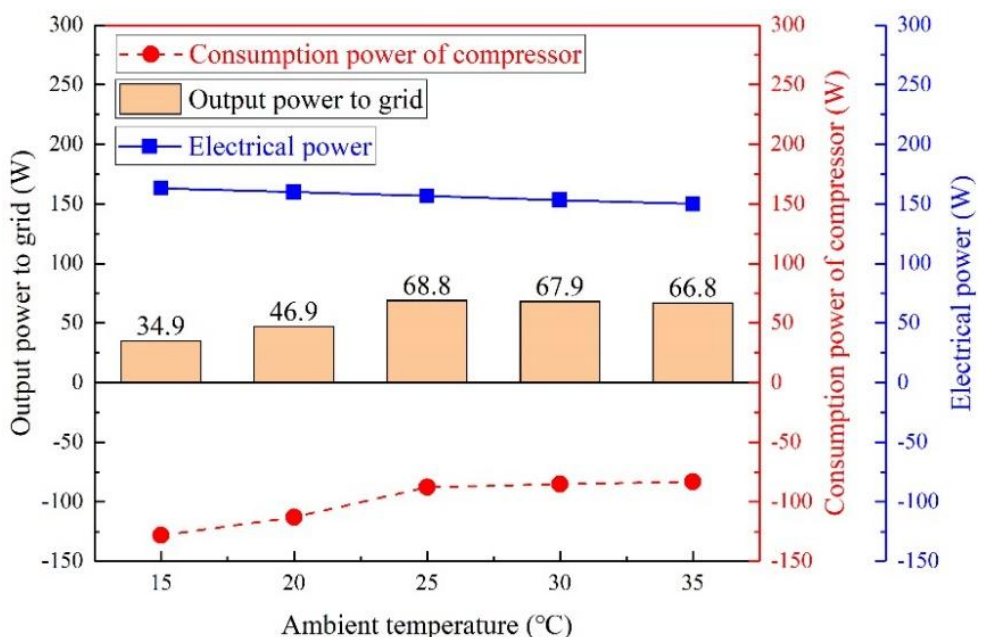

Ambient temperature $\left({ }^{\circ} \mathrm{C}\right)$

Fig. 17. Influence of ambient temperature on electrical power, consumption power of compressor and output power to grid.

\subsection{Wind speed}

The influences of wind speed which varying from $0.5 \mathrm{~m} / \mathrm{s}$ to $2.5 \mathrm{~m} / \mathrm{s}$ are shown as follows at the working conditions are: solar radiation intensity is $600 \mathrm{~W} / \mathrm{m}^{2}$, ambient temperature is $25^{\circ} \mathrm{C}$ and area of $\mathrm{PV} / \mathrm{T}$ collector is $2 \mathrm{~m}^{2}$.

Fig. 18 shows the variation curve of heating COP, thermal, electrical and overall efficiencies 
with wind speed varying from $0.5 \mathrm{~m} / \mathrm{s}$ to $2.5 \mathrm{~m} / \mathrm{s}$. The heating COP will decrease rapidly when the wind speed is low and steadily when the wind speed increases. More heat will be transferred to the environment and less heat is absorbed by the PV/T panel under a higher wind speed. Meanwhile, evaporation temperature of refrigerant will be decreased and the consumption power of compressor will be increased when the temperature of PV cells rises. Thus, the heating COP drops from 9.4 to 6.8 , which means better wind protection measures should be taken to improve the system performance.

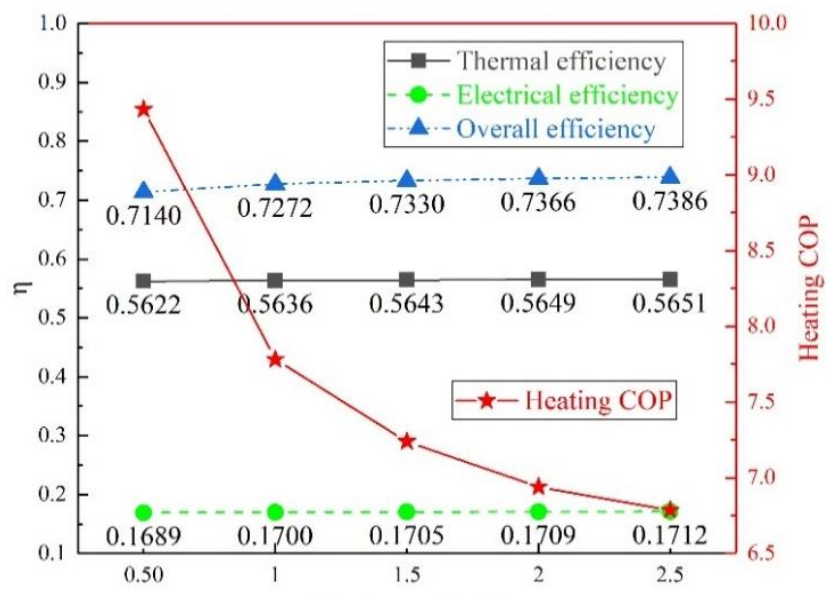

Wind speed $(\mathrm{m} / \mathrm{s})$

Fig. 18. Influence of wind speed on heating COP and thermal, electrical, overall efficiencies.

The variation curves of thermal and electrical power, pressure ratio and mass flow rate of the refrigerant with the increase of wind speed are shown in Fig. 19. The changing curves of the thermal and electrical power have the same trend as the thermal and electrical efficiencies. Both the pressure ratio and mass flow rate of refrigerant reduce with the increase of the wind speed. That is because more heat will be absorbed by the ambient air while less heat will be transferred by the refrigerant.

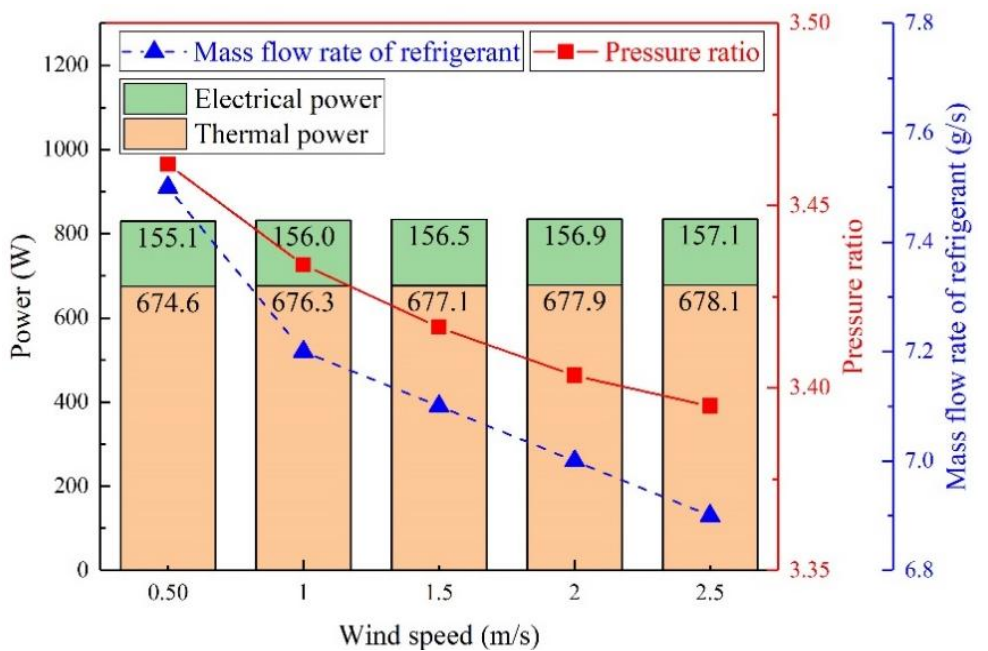

Wind speed $(\mathrm{m} / \mathrm{s})$

Fig. 19. Influence of wind speed on electrical and thermal power, pressure ratio and mass flow rate of refrigerant.

Fig. 20 presents the influence of wind speed on electrical power, consumption power of 
speed increases from $0.5 \mathrm{~m} / \mathrm{s}$ to $1.5 \mathrm{~m} / \mathrm{s}$ and steadily when the wind speed exceeds $1.5 \mathrm{~m} / \mathrm{s}$. More heat will loss in the environment due to a higher wind speed, and the thermal efficiency will decrease causing a higher consumption power of compressor.

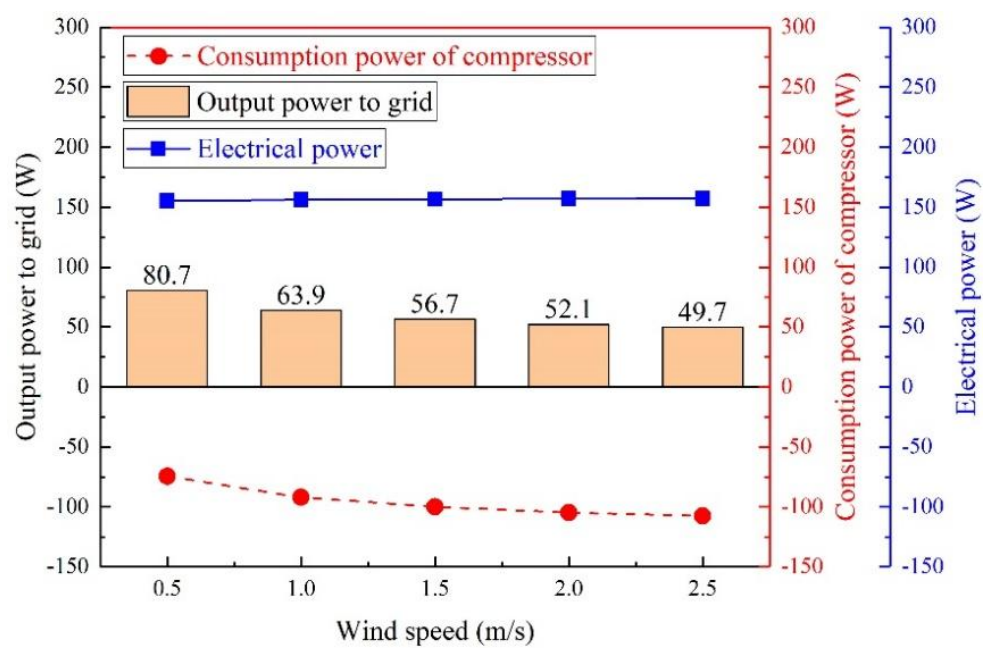

Fig. 20. Influence of wind speed on electrical power, consumption power of compressor and output power to grid.

\subsection{Area of PV/T collector}

The influences of the area of PV/T collector which varying from $1 \mathrm{~m}^{2}$ to $3 \mathrm{~m}^{2}$ are shown as follows at the working conditions are: solar radiation intensity is $600 \mathrm{~W} / \mathrm{m}^{2}$, ambient temperature is $25^{\circ} \mathrm{C}$ and wind speed is $1.5 \mathrm{~m} / \mathrm{s}$.

Fig. 21 presents the influence of the area of PV/T collector on pressure ratio, heating COP and overall efficiency. Pressure ratio and overall efficiency reduce with the increase of the area, while the heating COP mounts. That is because a larger area can absorb more heat from the solar radiation, and the extra heat will be transferred by PV/T panel to refrigerant. Meanwhile, the evaporation temperature and pressure will increase leading to a lower pressure ratio and a higher heating COP. The consumption power of the compressor will decrease when the pressure ratio reduces, thus the heating COP increases more rapidly under large area conditions. A higher temperature of the PV cells causes more heat dissipates in the ambient resulting a decrease of the overall efficiency. 


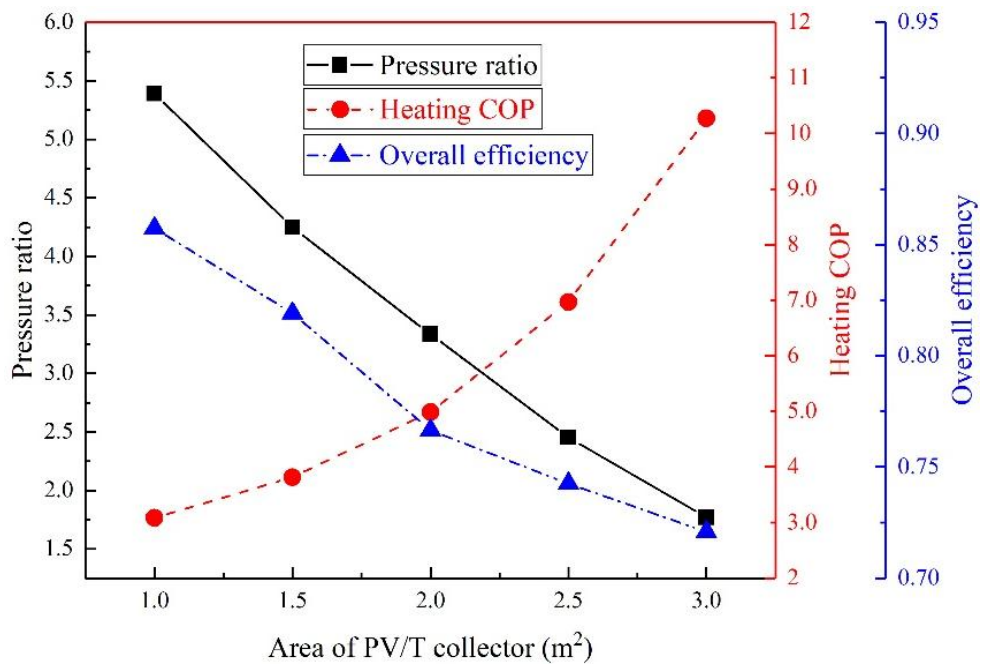

493

Fig. 21. Influence of the area of PV/T collector on pressure ratio, heating COP and overall efficiency.

Fig. 22 shows the declining trends of the pressure ratio and increasing trends of the thermal and electrical power influenced by the area of PV/T collector. The thermal and electrical output power are almost linearly and positively correlated with the area of PV/T collector. That is because more heat will gain from the solar radiation and be transferred to the refrigerant when the area increases.

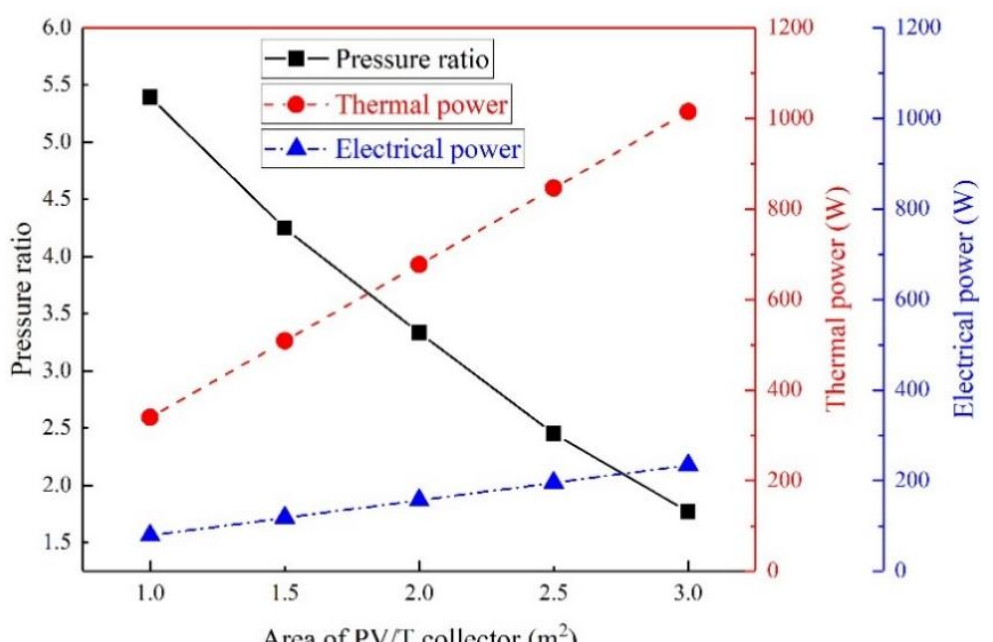

Fig. 22. Influence of the area of $\mathrm{PV} / \mathrm{T}$ collector on pressure ratio, thermal and electrical power.

As shown in Fig. 23, the mass flow rate of refrigerant will increase when the area increases, while the consumption power of compressor will increase when the area is below $1.5 \mathrm{~m}^{2}$ and decrease when the area is over $1.5 \mathrm{~m}^{2}$. The mass flow rate of refrigerant will increase because the latent heat and heat capacity of refrigerant are the same when more heat is transferred to the refrigerant. The heat absorbed by the PV/T panel and mass flow rate of refrigerant are low, thus the compressor consumes less electricity to compress the refrigerant vapor. With the increase of the area, the mass flow rate mounts resulting in an increase of consumption power. However, the pressure ratio of the compressor will reduce when the area increases over $1.5 \mathrm{~m}^{2}$ leading to a lower consumption power. 


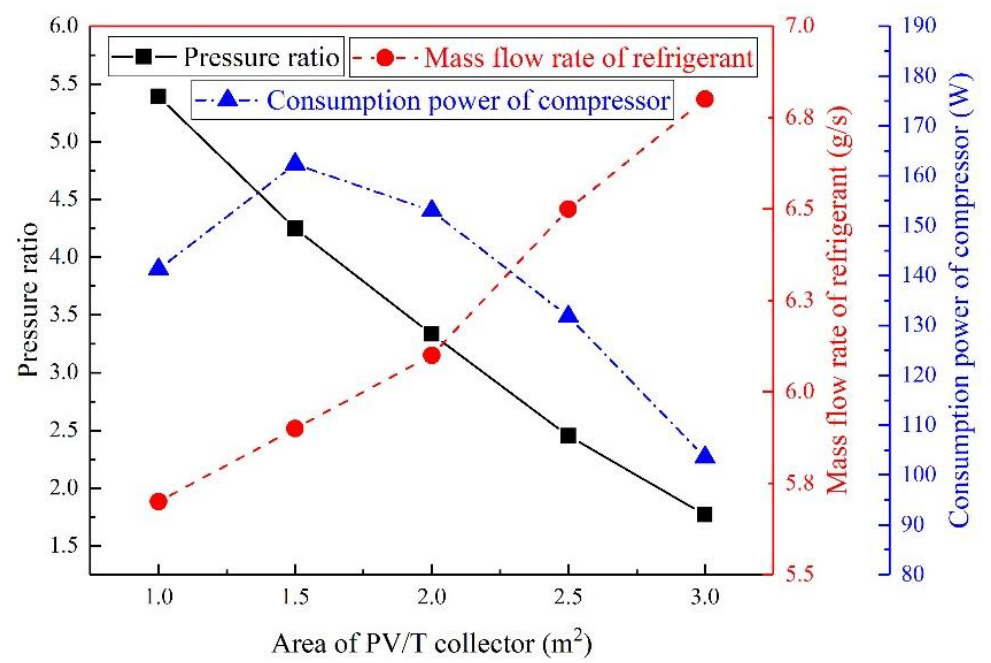

Fig. 23. Influence of the area of $\mathrm{PV} / \mathrm{T}$ collector on pressure ratio, mass flow rate of refrigerant and consumption power of compressor.

Fig. 24 illustrates the variation curve of output power to grid with the area of PV/T collector. The electrical power generated by PV panels will meet the demand of compressor when the area of PV/T collector is $2 \mathrm{~m}^{2}$. Moreover, the PV cells start to produce electricity to power grid when the area is over $2 \mathrm{~m}^{2}$ which means a larger PV/T panel is better for the system performance under the same system conditions.

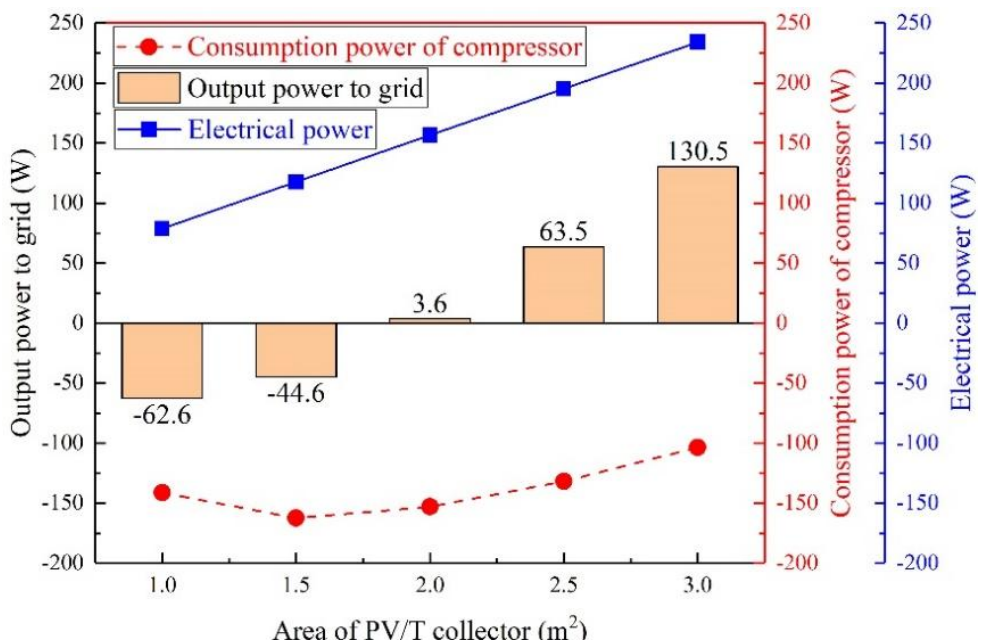

Area of PV/T collector $\left(\mathrm{m}^{2}\right)$

\subsection{Feasibility analysis of the system}

Nowadays, the Chinese government promotes the policy of using electricity for residential heating instead of burning coal for heating in northern China to reduce carbon dioxide emissions. The solar PV/T heat pump coupled with build-in PCM heat storage system is suitable for residential heating due to its advantages: (1) high efficiency; (2) low energy consumption; (3) stable residential heating supply; (4) zero carbon emissions. Table. 4 presents the typical operating conditions and parameters of the system. It is a typical spring/autumn day in northern China. 
Table. 4. Typical operating conditions and parameters of the system.

\begin{tabular}{llll}
\hline Parameters & Nomenclature & Value & Unit \\
\hline Solar radiation intensity & $I$ & 600 & $\mathrm{~W} / \mathrm{m}^{2}$ \\
Sunshine duration & $t_{s}$ & 8 & hour \\
Ambient temperature & $T_{a}$ & 15 & ${ }^{\circ} \mathrm{C}$ \\
Wind speed & $v_{\text {wind }}$ & 1.5 & $\mathrm{~m} / \mathrm{s}$ \\
Area of the collector & $A$ & 20 & $\mathrm{~m}^{2}$ \\
Packing factor & $\beta_{p}$ & 1 & {$[-]$} \\
Heating area & $A_{h a}$ & 100 & $\mathrm{~m}^{2}$ \\
Heat loss per square meter & $P_{L}$ & 50 & $\mathrm{~W} / \mathrm{m}^{2}$ \\
Filling volume of the PCM & $V_{P C M}$ & 0.57 & $\mathrm{~m}^{3}$ \\
External diameter of the inside pipe & $D_{l}$ & 0.012 & $\mathrm{~m}$ \\
Internal diameter of the inside pipe & $d_{l}$ & 0.010 & $\mathrm{~m}$ \\
External diameter of the outside pipe & $D_{2}$ & 0.074 & $\mathrm{~m}$ \\
Internal diameter of the outside pipe & $d_{2}$ & 0.072 & $\mathrm{~m}$ \\
Length of the PCM heat exchanger & $L_{h x}$ & 164 & $\mathrm{~m}$ \\
\hline
\end{tabular}

Table. 5 presents the simulation performance indices of the system under typical day conditions. The PV/T collector can transfer 213.9 MJ heat from the ambient to the PCM heat exchanger, and the heat will be stored in phase change materials and concrete. The build-in PCM heat storage can release the heat for 10 hours at $5.94 \mathrm{~kW}$ during the night while the heat loss power of $100 \mathrm{~m}^{2}$ area is $5 \mathrm{~kW}$. During autumn, winter and early spring in northern China, the heating system is necessary to keep indoor temperature above $20^{\circ} \mathrm{C}$. Thus, the system can achieve the heating needs of the users and keep the indoor temperature steady. Meanwhile, the system can output $21.4 \%(2.79 \mathrm{kWh})$ of the power generated by PV panels to the grid while $78.6 \%$ of it consumed by the compressor. The heating COP of the system is 5.79 , and the overall efficiency is $75.49 \%$.

Table. 5. Simulation performance indices of the system under typical day conditions.

\begin{tabular}{lll}
\hline Parameters & Value & Unit \\
\hline Total heat storage & 213.9 & $\mathrm{MJ}$ \\
Photovoltaic power & 1.63 & $\mathrm{~kW}$ \\
Photovoltaic efficiency & 17.77 & $\%$ \\
PV/T thermal efficiency & 55.76 & $\%$ \\
Heating COP & 5.79 & {$[-]$} \\
Overall efficiency & 75.49 & $\%$ \\
Cumulative power generation & 13.05 & $\mathrm{kWh}$ \\
Consumption power of compressor & 10.26 & $\mathrm{kWh}$ \\
Output power to grid & 2.79 & $\mathrm{kWh}$ \\
Temperature range of underfloor heating & $22-31$ & ${ }^{\circ} \mathrm{C}$ \\
Heating power at night & 5.94 & $\mathrm{~kW}$ \\
Heat loss power & 5.00 & $\mathrm{~kW}$ \\
Heating hour & 10.00 & $\mathrm{hour}$ \\
\hline
\end{tabular}

Table. 6 illustrates the comparison of cost between the proposed system and conventional air 
conditioning system. The operating cost of the proposed system is under zero because users could sell spare electricity to power grid and get profit. Fig. 25 shows the cost variation curves of these two systems. The initial cost of the proposed system is much higher than conventional air conditioning system due to the underfloor heating equipment and PV/T panels, etc. However, the air conditioning system consumes a lot of electricity during the night for heating supply. Thus, the cost of these two systems will be the same after about 4 years, and the cost of proposed system keeps reduce while the cost of air conditioning system still climbs. Moreover, underfloor heating system which using radiative heating is more comfort and silence for users than air conditioner.

Table. 6. Cost comparison between the proposed system and conventional air conditioning system.

\begin{tabular}{lccc}
\hline Heating system & $\begin{array}{c}\text { Initial } \\
\text { cost } ¥)\end{array}$ & $\begin{array}{c}\text { Operating } \\
\text { cost (¥/year) }\end{array}$ & $\begin{array}{c}\text { Maintenance } \\
\text { cost (¥/year) }\end{array}$ \\
\hline Proposed system & 22000 & -764 & 550 \\
Air conditioning system & 4500 & 4024 & 225 \\
\hline
\end{tabular}

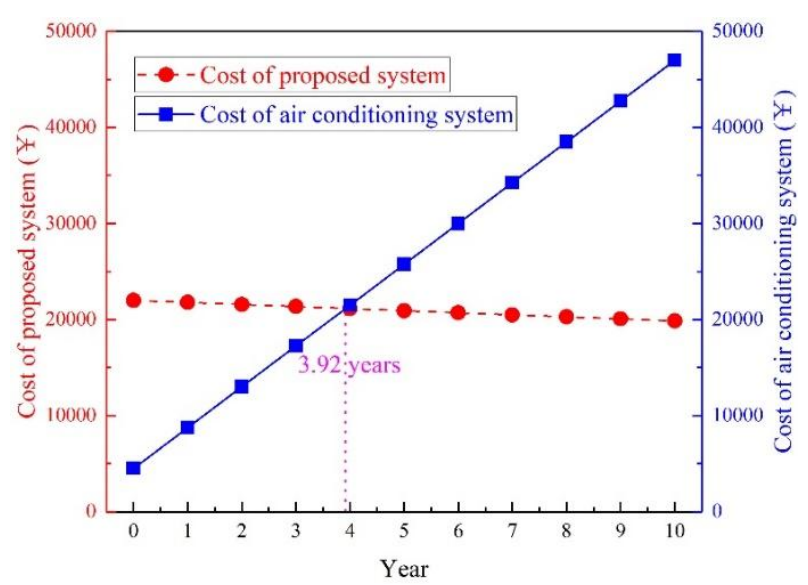

Fig. 25. Cost variation curves of proposed system and air conditioning system.

\section{Conclusion}

A building-coupled cogeneration system using solar PV/T heat pump and build-in PCM heat storage is proposed in this paper. The mathematical model of the system is established and verified to analyze the system performance under different conditions. The main conclusions can be drawn as follows:

(1) The temperature of underfloor heating which using build-in PCM heat storage can reach $22{ }^{\circ} \mathrm{C}$ to $31^{\circ} \mathrm{C}$ after 39 hours when the circulating water is $40{ }^{\circ} \mathrm{C}$ which is stable and suitable for residential heating.

(2) The heating COP can reach 6.6 which is $94 \%$ higher than conventional air conditioning system when solar radiation intensity is $600 \mathrm{~W} / \mathrm{m}^{2}$, ambient temperature is $25^{\circ} \mathrm{C}$, wind speed is 1.5 $\mathrm{m} / \mathrm{s}$ and area of PV/T collector is $2 \mathrm{~m}^{2}$ while the electrical, thermal and overall efficiencies are $17.05 \%, 56.43 \%$ and $73.87 \%$, respectively.

(3) A $2 \mathrm{~m}^{2} \mathrm{PV} / \mathrm{T}$ panel can meet the power demand of the system and heating demand of a 10 $\mathrm{m}^{2}$ room when the solar radiation intensity is $500 \mathrm{~W} / \mathrm{m}^{2}$. Moreover, the PV/T panel can output electricity to power grid if the panel area is bigger than $2 \mathrm{~m}^{2}$ or solar radiation intensity is higher 
than $500 \mathrm{~W} / \mathrm{m}^{2}$.

The mathematical model established in this paper can also be used to analyze and optimize the solar PV/T heat pump system. However, the mathematical model of this system is for stable working conditions instead of transient. The establishment of dynamic model is needed for further predict and analyze accurately of solar assisted heat pump system under dynamic working conditions.

\section{Acknowledgements}

This research work is funded by the International Research Cooperation Program of Shanghai (Grant No. 18160710500).

\section{Nomenclature:}

\section{Symbols}

A

W

\section{$L$}

$\Delta H$

$h$

$U$

$C_{p}$

$d$

$D$

$t / T$

$I$

$Q$

F

$R$

Re

$R a$

$\operatorname{Pr}$

$v$

$m$

$g$

$p$

$P$

V

589

590 Greek symbols

$\delta$

$\tau$ area $\left(\mathrm{m}^{2}\right)$

width of the $\mathrm{PV} / \mathrm{T}$ collector/evaporator $(\mathrm{m})$

length of the PV/T collector/evaporator (m)

latent heat $(\mathrm{kJ} / \mathrm{kg})$

heat transfer coefficient $\left(\mathrm{W} / \mathrm{m}^{2} \cdot \mathrm{K}\right)$

heat loss coefficient $\left(\mathrm{W} / \mathrm{m}^{2} \cdot \mathrm{K}\right)$

specific heat at constant pressure $(\mathrm{kJ} / \mathrm{kg} \cdot \mathrm{K})$

inner diameter $(\mathrm{m})$

external diameter $(\mathrm{m})$

temperature $(\mathrm{K})$

solar radiation intensity $\left(\mathrm{W} / \mathrm{m}^{2}\right)$

heat transfer rate $(\mathrm{W})$

collector efficiency (-)

thermal resistance $\left(\mathrm{m}^{2} \cdot \mathrm{K} / \mathrm{W}\right)$

Reynolds number (-)

Rayleigh number (-)

Prandtl number (-)

wind speed $(\mathrm{m} / \mathrm{s})$

mass flowrate $(\mathrm{kg} / \mathrm{s})$

gravitational acceleration $\left(\mathrm{m} / \mathrm{s}^{2}\right)$

pressure $(\mathrm{kPa})$

power $(\mathrm{W})$

volume flow rate $\left(\mathrm{m}^{3} / \mathrm{h}\right)$
thickness (m)
transmittance (-) 


$\begin{array}{ll}a & \text { absorption ratios }(-) \\ \beta & \text { packing factor }(-) \\ \varepsilon & \text { emissivity }(-) \\ \kappa & \text { thermal conductivity }(\mathrm{W} / \mathrm{m} \cdot \mathrm{K}) \\ \sigma & \text { Stefan-Boltzmann constant }(-) \\ \rho & \text { density }\left(\mathrm{kg} / \mathrm{m}^{3}\right) \\ \lambda & \text { compressor volumetric efficiency (-) } \\ \eta & \text { efficiency }(-) \\ \chi & \text { polytropic index }(-)\end{array}$

592 Subscripts

\begin{tabular}{|c|c|}
\hline$p, p v$ & PV cells \\
\hline$g, c_{1}$ & external glass cover \\
\hline$c / c_{2}$ & PV-glazing cover \\
\hline conc & concrete \\
\hline$E V A$ & EVA grease \\
\hline$P C M$ & phase change materia \\
\hline mel & melting point \\
\hline ref & refrigerant \\
\hline$b$ & baseboard \\
\hline$c v$ & convection \\
\hline$r d$ & radiation \\
\hline$r b$ & roll-bond panel pipe \\
\hline$a$ & ambient \\
\hline$l$ & liquid \\
\hline$L$ & lost \\
\hline$r c$ & reference \\
\hline$e$ & electrical \\
\hline$e i$ & electrical insulation \\
\hline$u$ & uesful \\
\hline$t h / R$ & thermal \\
\hline$t p$ & two-phase flow \\
\hline ove & oveall \\
\hline$a b s$ & absorb \\
\hline$h p$ & heat pipe \\
\hline$s h$ & superheated \\
\hline$v$ & vapor \\
\hline cond & condensation \\
\hline eva & evaporation \\
\hline ot & outer pipe \\
\hline$e q$ & equivalent \\
\hline$h x$ & heat exchanger \\
\hline dis & discharge \\
\hline suc & suction \\
\hline
\end{tabular}




$\begin{array}{ll}\text { in } & \text { inlet } \\ \text { out } & \text { outlet } \\ \text { cw } & \text { circulating water }\end{array}$

\section{References:}

2019. Review and outlook of world energy development, Non-Fossil Energy Development in China. pp. 1-36.

Ahn, J.-G., Kim, J.-H., Kim, J.-T., 2015. A Study on Experimental Performance of Air-Type PV/T Collector with HRV. Energy Procedia 78, 3007-3012.

Al-Waeli, A.H.A., Sopian, K., Kazem, H.A., Chaichan, M.T., 2017. Photovoltaic/Thermal (PV/T) systems: Status and future prospects. Renewable and Sustainable Energy Reviews 77, 109-130.

Cabeza, L.F., Castell, A., Barreneche, C., de Gracia, A., Fernández, A.I., 2011. Materials used as PCM in thermal energy storage in buildings: A review. Renewable and Sustainable Energy Reviews 15(3), 1675-1695.

Caetano, N.S., Mata, T.M., Martins, A.A., Felgueiras, M.C., 2017. New Trends in Energy Production and Utilization. Energy Procedia 107, 7-14.

Del Amo, A., Martínez-Gracia, A., Bayod-Rújula, A.A., Cañada, M., 2019. Performance analysis and experimental validation of a solar-assisted heat pump fed by photovoltaic-thermal collectors. Energy 169, 1214-1223.

Diallo, T.M.O., Yu, M., Zhou, J., Zhao, X., Shittu, S., Li, G., Ji, J., Hardy, D., 2019. Energy performance analysis of a novel solar PVT loop heat pipe employing a microchannel heat pipe evaporator and a PCM triple heat exchanger. Energy 167, 866-888.

Fayaz, H., Rahim, N.A., Hasanuzzaman, M., Rivai, A., Nasrin, R., 2019. Numerical and outdoor real time experimental investigation of performance of PCM based PVT system. Solar Energy 179, 135-150.

Fiorentini, M., Cooper, P., Ma, Z., Robinson, D.A., 2015. Hybrid Model Predictive Control of a Residential HVAC System with PVT Energy Generation and PCM Thermal Storage. Energy Procedia 83, 21-30.

Hosseinzadeh, M., Sardarabadi, M., Passandideh-Fard, M., 2018. Energy and exergy analysis of nanofluid based photovoltaic thermal system integrated with phase change material. Energy 147, 636-647.

Hu, J., Chen, W., Yang, D., Zhao, B., Song, H., Ge, B., 2016. Energy performance of ETFE cushion roof integrated photovoltaic/thermal system on hot and cold days. Applied Energy 173, 40-51. Huang, B.J., Lee, C.P., 2004. Long-term performance of solar-assisted heat pump water heater. Renewable Energy 29(4), 633-639.

Huide, F., Xuxin, Z., Lei, M., Tao, Z., Qixing, W., Hongyuan, S., 2017. A comparative study on three types of solar utilization technologies for buildings: Photovoltaic, solar thermal and hybrid photovoltaic/thermal systems. Energy Conversion and Management 140, 1-13.

Jankowski, N.R., McCluskey, F.P., 2014. A review of phase change materials for vehicle component thermal buffering. Applied Energy 113, 1525-1561.

Kazemian, A., Salari, A., Hakkaki-Fard, A., Ma, T., 2019. Numerical investigation and parametric analysis of a photovoltaic thermal system integrated with phase change material. Applied Energy 238, 734-746. 
Keček, D., Mikulić, D., Lovrinčević, Ž., 2019. Deployment of renewable energy: Economic effects on the Croatian economy. Energy Policy 126, 402-410.

Kuik, O., Branger, F., Quirion, P., 2019. Competitive advantage in the renewable energy industry: Evidence from a gravity model. Renewable Energy 131, 472-481.

Kuznik, F., Virgone, J., Roux, J.-J., 2008. Energetic efficiency of room wall containing PCM wallboard: A full-scale experimental investigation. Energy and Buildings 40(2), 148-156.

Li, G., Pei, G., Ji, J., Yang, M., Su, Y., Xu, N., 2015. Numerical and experimental study on a PV/T system with static miniature solar concentrator. Solar Energy 120, 565-574.

Ma, Y., 2013. Analysis of Electrical Efficiency for Positive Displacement Refrigerant Compressor. Journal of Refrigeration.

Mojumder, J.C., Chong, W.T., Ong, H.C., Leong, K.Y., Abdullah Al, M., 2016. An experimental investigation on performance analysis of air type photovoltaic thermal collector system integrated with cooling fins design. Energy and Buildings 130, 272-285.

Nahar, A., Hasanuzzaman, M., Rahim, N.A., 2017. A Three-Dimensional Comprehensive Numerical Investigation of Different Operating Parameters on the Performance of a Photovoltaic Thermal System With Pancake Collector. Journal of Solar Energy Engineering 139(3), 031009. Othman, M.Y., Hamid, S.A., Tabook, M.A.S., Sopian, K., Roslan, M.H., Ibarahim, Z., 2016. Performance analysis of PV/T Combi with water and air heating system: An experimental study. Renewable Energy 86, 716-722.

P. Hartnett, J., M. Rohsenow, W., 1973. Handbook of Heat Transfer. Paolo Frankl, S., 2010. Technology Roadmap: Solar Photovoltaic Energy.

Pereira da Cunha, J., Eames, P., 2016. Thermal energy storage for low and medium temperature applications using phase change materials - A review. Applied Energy 177, 227-238.

Pietrosemoli, L., Rodríguez-Monroy, C., 2019. The Venezuelan energy crisis: Renewable energies in the transition towards sustainability. Renewable and Sustainable Energy Reviews 105, 415-426.

Qiu, Z., Zhao, X., Li, P., Zhang, X., Ali, S., Tan, J., 2015. Theoretical investigation of the energy performance of a novel MPCM (Microencapsulated Phase Change Material) slurry based PV/T module. Energy 87, 686-698.

R. Turns, S., 2006. Thermodynamics. Concepts and applications.

Stojanović, B., Akander, J., 2010. Build-up and long-term performance test of a full-scale solar-assisted heat pump system for residential heating in Nordic climatic conditions. Applied Thermal Engineering 30(2-3), 188-195.

Tsai, H.-L., 2015. Modeling and validation of refrigerant-based PVT-assisted heat pump water heating (PVTA-HPWH) system. Solar Energy 122, 36-47.

Wolf, M., 1976. Performance analyses of combined heating and photovoltaic power systems for residences. Energy Conversion 16(1), 79-90.

Zhou, C., Liang, R., Zhang, J., Riaz, A., 2019. Experimental study on the cogeneration performance of roll-bond-PVT heat pump system with single stage compression during summer. Applied Thermal Engineering 149, 249-261. 


\section{Conflict of Interest}

We declare that there are no conflicts of interest in the work we submitted. 


\section{Shanghai Jiao Tong University}

Prof. Yanjun Dai, Engineering Research Center of Solar Power and Refrigeration, Dongchuan Road 800\#, Shanghai, 200240, P.R. China.

Dear Editor,

Enclosed please find our manuscript entitled: "Performance analysis of solar assisted heat pump coupled with build-in PCM heat storage based on PV/T panel" (written by J. Yao, H. Xu, Y. J. Dai * M. J. Huang), for possible publication in SOLAR ENERGY. The paper has been prepared according to the guidelines listed in the "Guide for Authors-Contents List". The paper has been received by ' 1 st International Conference for Global Chinese Academia on Energy and Built Environment', and the number of Abstract is 2019-601.

We appreciate your consideration of our manuscript, and look forward to receiving comments from the reviewers. Please acknowledge receipt of this manuscript at your convenience, and let us know if you need any further information.

Thanks for your consideration.

Sincerely,

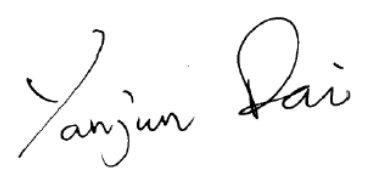

Prof. Yanjun Dai (Y.J. Dai)

Engineering Research Center of Solar Power and Refrigeration

Shanghai Jiao Tong University

Shanghai, 200240, P.R. China 